\title{
Working
}

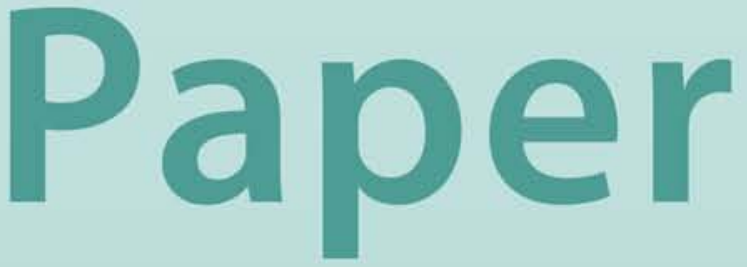




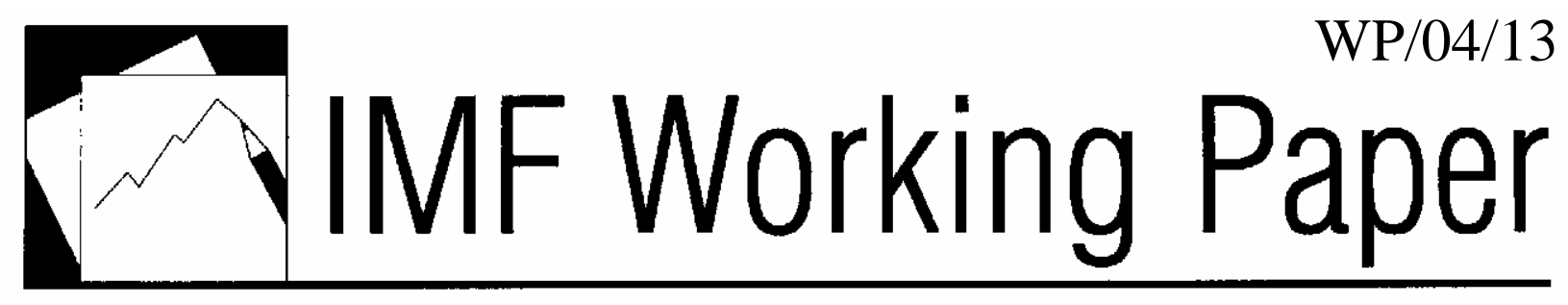

How Private Creditors Fared in Emerging Debt Markets, 1970-2000

Christoph Klingen, Beatrice Weder, and

Jeromin Zettelmeyer 


\title{
IMF Working Paper
}

\author{
Research Department
}

\section{How Private Creditors Fared in Emerging Debt Markets, 1970-2000}

\author{
Prepared by Christoph Klingen, Beatrice Weder, and Jeromin Zettelmeyer $^{1}$ \\ Authorized for distribution by Eduardo Borensztein and Robert J.Corker
}

January 2004

\begin{abstract}
This Working Paper should not be reported as representing the views of the IMF. The views expressed in this Working Paper are those of the author(s) and do not necessarily represent those of the IMF or IMF policy. Working Papers describe research in progress by the author(s) and are published to elicit comments and to further debate.
\end{abstract}

We estimate ex post returns to emerging market debt by combining secondary-market prices with observed flows based on World Bank data. From 1970-2000, returns averaged 9 percent per annum, about the same as returns on a ten-year U.S. treasury bond. This reflects the combined effect of the 1980s debt crisis and much higher returns during 1989-2000. Annual returns since 1986 have been less volatile than emerging market equity returns but more volatile than returns on U.S. corporate or high-yield bonds. However, unlike returns on these bonds, emerging market debt returns do not seem significantly correlated with U.S. or world stock markets.

JEL Classification Numbers: F21, F34

Keywords: sovereign debt, crises, returns capital flows

Authors’ E-Mail Addresses: cklingen@imf.org; beatrice.weder@uni-mainz.de; jzettelmeyer@imf.org

\footnotetext{
${ }^{1}$ The authors are with the International Monetary Fund, the University of Mainz, and International Monetary Fund, respectively. Without implication, we are extremely grateful to Punam Chuhan, Ibrahim Levent, and particularly Nevin Fahmy of the World Bank's Financial Data team for providing us with debt data and answering countless questions. We also thank Joyce Chang, Jarrad Linzie, and Alvin Ying of the J.P. Morgan Research Department for providing us with data on bond prices and duration. Eduardo Borensztein, Charles Blitzer, Giancarlo Corsetti, Monica de Bolle, Allan Drazen, Mike Dooley, Rachel Glennerster, Olivier Jeanne, Oliver Fratzscher, Julie Kozack, Leslie Lipschitz, Jens Nysted, Laura Papi, Richard Portes, Juan Solé, and Shang-Jin Wei provided valuable comments and suggestions, as did seminar participants at the 2002 NBER Summer Institute, the Board of Governors of the Federal Reserve System, the European Central Bank, the IMF, the World Bank, the $5^{\text {th }}$ CEPR/RTN Conference on International Capital Markets in Gerzensee, (Switzerland), George Washington University and the Universities of Dortmund, Maryland, Freiburg, and Zurich. Priya Joshi provided outstanding research assistance and prepared Appendix II. An earlier version of this paper was presented at the 2003 IMF Annual Research Conference.
} 


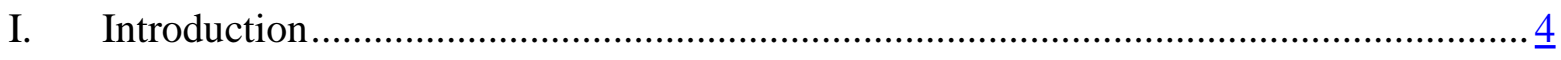

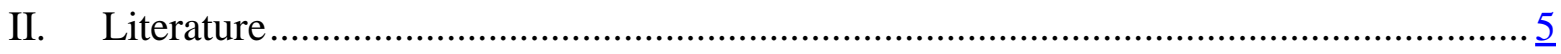

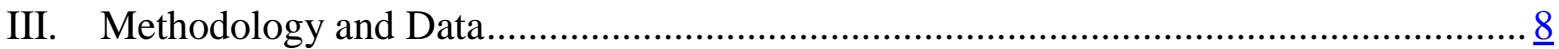

A Measuring Net Transfers Between Creditors and Debtors ............................... $\underline{8}$

B. Valuing Debt Stocks and Adressing Survival Bias...................................... 12

C. Computing Rates of Return for Alternative Assets .................................... 14

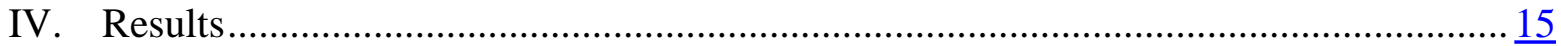

A. Alternative Estimates of Net Tranfers ..................................................... $\frac{15}{18}$

B. Long-Run Debt Returns, 1970-2000 ......................................................... $\frac{18}{25}$

C. Changes in Debt Returns Over Time .......................................................... $\frac{25}{34}$

D. Volatility and Comovement with Returns on Other Asset Classes ................... $\underline{34}$

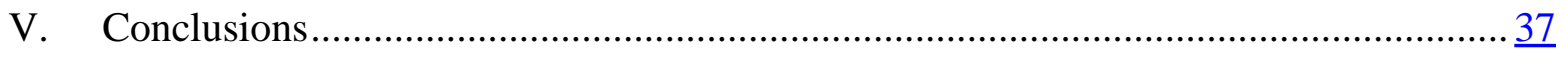

Appendix

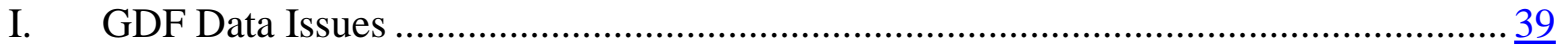

II. Secondary-Market Price Data, Sources, and Methodology ..................................... $\frac{43}{54}$

III. Computation of Net Transfers on Alternative Investment................................... $\frac{54}{56}$

IV. Country-Level Results on Volatility ........................................................ $\underline{56}$

\section{Tables}

1. Average Duration of EMBIG Debt in Our Sample................................14

2. Comparison of Assumptions ............................................................................ 17

3. Countries with Secondary-Market Prices in 2000: Ex Post Returns

to Private Creditors, 1970-2000 ........................................................................... 19

4. Countries with Secondary-Market Prices in 1991: Aggregate Ex Post Returns to Private Creditors, 1970-2000 ............................................................... 22

5. Countries with Secondary-Market Prices in 2000: Price Sensitivity of Ex Post Sovereign Returns to Private Creditors.................................................................... 23

6. The "Eighties" Versus the "Nineties": Ex Post Spreads, Sovereign Debt,

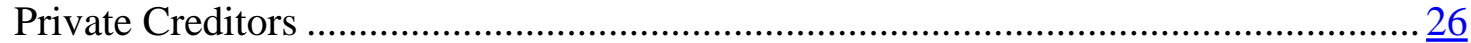

7. Brady Deal Countries: Ex Post Sovereign Spreads up to Brady Deal Year ................. 28

8. Decomposing Spreads, 1970-89, 1989-94, and 1994-2000: Ex Post Sovereign Spreads, Private Creditors ......................................................................................... 29

9. Spreads over Three-Year Periods: Ex Post Spreads, Public and Publicly Guaranteed Debt, Private Creditors ........................................................................ 31

10. Average Long-Run Spreads over an Increasing Horizon: Ex Post Spreads, Public and Publicly Guaranteed Debt, Private Creditors ....................................... $\underline{33}$

11. Returns, Volatility, and Betas: Results for Aggregate Flows .................................. $\underline{35}$ 
Appendix Tables

1. Aggregated Secondary-Market Prices, 1986-2001 …......................................... 45

2. Secondary-Market Loan Prices, 1986-2001 …....................................................... $\frac{46}{47}$

3. Secondary-Market Brady Bond Prices, 1986-2001 ............................................. $\frac{47}{48}$

4. Secondary-Market Non-Brady Bond Prices, 1986-2001 ........................................ $\frac{48}{52}$

5. Representativeness of Prices in All Outstanding Privately Held Debt ....................... $\underline{52}$

6. Representativeness of Prices in All Public and Publicly Guaranteed

Privately Held Debt.................................................................................. 53

7. Returns, Volatility, and Betas: Results for Individual Countries............................. $\underline{56}$

8. Returns over One-Year Holding Periods ........................................................ $\frac{57}{57}$

\section{Figures}

1. External Debt of Developing Countries, 1970-2000 .......................................... $\frac{16}{18}$

2. Net Transfers on Debt to 22 Emerging Market Countries, 1970-90 .......................... 18

3. Countries with Secondary-Market Prices in 2000: Average Returns and Ex Post Spreads for Public and Publicly Guaranteed Debt, 1970-2000................................. 20

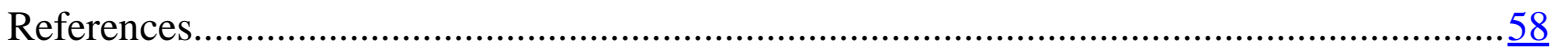




\section{INTRODUCTION}

How high are average returns to emerging market lending —in particular, sovereign lending-over long periods? How volatile are they over shorter periods? How correlated are they with returns on other assets, such as U.S. equities or U.S. high-yield bonds? After the dust settles in debt crises and restructurings are renegotiated, how much do private creditors actually lose? Ex post, have creditors of countries that did default fared much worse than creditors of other emerging market countries that did not? How have average returns evolved over time-in particular, from the 1980s to the 1990s?

Investigating questions of this type is critical for understanding emerging market debt as an asset class. But it also has important implications for the ongoing debate on reforming the international financial architecture, limiting IMF bailouts, and perhaps finding alternative ways to deal with sovereign debt problems. For example, it is generally assumed that the official sector's approach to crisis management in the second half of the 1990s, the era of large-scale crisis lending, was very different from that followed during the 1980s, when there were no big bailouts and private creditors supposedly suffered heavy losses and that differences in the official sector's approach to crisis countries in the 1990s made a difference in terms of how private investors fared. Yet there is little evidence supporting (or refuting) such views. In part, this is because of the difficulties of computing the ex post returns associated with individual loans or debt instruments in the face of rollovers, defaults, and debt restructurings. To do this, one would either need to know the market value of the claim at the time of the restructuring or track actual cash flows deriving from this claim. This is hard to do, particularly for bank loans, which were not publicly traded until the late 1980s and constituted the main vehicle for emerging market borrowing until the 1990s.

This paper estimates returns to emerging market lending from the perspective of private creditors, for both the entire period since private debt flows took off in the early 1970s and a set of shorter subperiods since the mid-1980s. Following Lindert (1989), Cohen (1992), and Klingen (1994), we sidestep the difficulties associated with computing investor returns for particular episodes and debt instruments by focusing on aggregate lending to countries and comparatively broad debt categories. This permits us to use the World Bank's Global Development Finance (GDF) database (available annually since 1970) as our main source for debt flows between creditors and debtor countries. While the published data need to be adjusted to ensure that we capture all cash flows associated with an initial disbursement and vice versa, the use of broad debt concepts makes this a comparatively manageable problem, and the necessary adjustments can be made using available (although generally unpublished) data collected by the World Bank. We then use these adjusted flows to compute internal rates of return. Outstanding debt stocks_-as well as initial debt stocks, when computing returns over subperiods - are valued at secondary-market debt prices.

Our study relates to an empirical literature on returns to international debt and equity which is briefly surveyed in the following section. It adds to this literature in several ways. First, it is the first paper to study returns on postwar emerging-market debt over a long horizon that includes both the 1980s debt crisis and the boom-bust cycle of the 1990s. Second, we 
enhance the robustness of the results by basing our calculations on two alternative approaches to recovering the flows between creditors and debtors from World Bank data. Third, we also look at the evolution of returns over shorter horizons and compare returns over subperiods defined by cycles in net flows or by historical events. To do this, we collect secondary-market price data since 1986 from a variety of sources and use it to construct average year-end debt prices for several classes of instruments as well as aggregate debt. Fourth, we provide a rudimentary characterization of the volatility of annual returns since the late 1980s, as well as the covariance with returns on alternative asset classes such as emerging market equities, U.S. equities, and U.S. high-yield bonds. All results are shown both for aggregate flows and separately for the main debtor countries.

The main findings are as follows. During 1970-2000, returns averaged about 9 percent per annum, about the same as that on a 10-year U.S. government bond. In other words, ex post risk premiums over the entire 1970-2000 period were close to zero. This result holds not just for aggregate flows, but - approximately - for most of the major debtor countries, whose rates of return are clustered in the range between 8 percent and about 10.5 percent. However, it masks considerable heterogeneity in the time dimension. The 1970-2000 period can be decomposed into a 1970-89 cycle with negative or very low returns, a period of very high returns from 1989 until 1993, and a period of lower but positive ex post spreads since then. Thus, the boom of the 1990s seems to be driven to a large extent by development during the 1989-93 period, which preceded large-scale crisis lending. Finally, we find that the volatility of annual emerging debt returns since 1986 is higher than that of returns on U.S. corporate or high-yield bonds, but far lower than the volatility of emerging-market-equity returns. Like emerging-market equities (but unlike U.S. corporate and high-yield bonds), emerging-market debt returns seem to have exhibited little correlation with the U.S. and world stock markets during this period.

\section{LiterATURE}

This paper is related to several strands of the literature. Most directly related to this paper is a small set of studies that attempt to compute ex post returns of emerging market debt across historical periods that include defaults or debt restructurings. In an extensive study of sovereign debt in the interwar period, Eichengreen and Portes (1986) track the payment histories of a random sample of U.S. dollar bonds issued by foreign borrowers in the United States and colonial and foreign government bonds issued in pound sterling in the 1920s. They then compute internal rates or return based on observed interest and principal payments. The nominal rate of return turns out to be about 5.4 percent on average for the sterling bonds and 3.3 percent for the dollar bonds owed or guaranteed by governments. What is remarkable is that these rates are quite close to government bond rates that contained virtually no default risk (4.5 for sterling consols and 4.1 for high grade municipal dollar bonds, respectively). In a related paper, Lindert and Morton (1990) compute rates of return on foreign government bonds issued by ten large borrowers in the 1850-1914, 1915-45 and post-1954 periods. Their result is rather similar: excess rates of return relative to domestic government bonds were on average quite small (about 0.4 percentage points). As we shall see, this mirrors results obtained in this paper for the 1970-2000 period. 
Several authors have attempted a similar exercise for the 1980s debt crisis, using data about privately held debt stocks and flows compiled by the World Bank. Lindert (1989) calculates internal rates of return to private lending during 1973-1986 under a full repayment and a complete default scenario. He points to a number of potential problems with using flow data as reported by the World Bank for the purposes of computing internal rates of return, and instead suggests imputing flows from changes in debt stocks. ${ }^{2}$ In contrast, Cohen (1992) uses reported flows to calculate debt repayments up to 1989 as a share of 1982 debt outstanding, on the grounds that changes in stocks mismeasure flows to the extent that they reflected changes in the currency valuation of debt (i.e. cross-exchange rate movements with respect to the U.S. dollar). While agreeing with Cohen on this point, Klingen (1994) argued that Lindert's original reasons for constructing flows based on changes in stocks remained valid, and proposed a refinement of Lindert's approach that adjusts for changes in currency valuation, among several other adjustments. Using this methodology, he computed internal rates of return for privately held debt for the 1970-92 period, using secondary market prices to value the end stock. His main conclusion is that private creditors fared surprisingly well during this period, considering that a major debt crisis took place, earning average dollar rates of 8 percent in nominal and 2 percent in real terms.

Second, since the mid-1990s, there is an empirical finance literature on returns to emerging market equity (see Harvey, 1995a, 1995b; Bekaert and Harvey, 1997, 2000; Goetzmann and Jorion, 1999; and Rouwenhorst, 1999, among others). Bekaert and Harvey (1997) conclude that "there are four distinguishing features of emerging [equity] market returns: average returns are higher, correlations with developed market returns are low, returns are more predictable and volatility is higher." More recently, there has been some work on emerging bond market returns and their correlations with equity returns (Kelly, Martins, and Carlson, 1998; Erb, Harvey, and Viskanta, 1999). These studies focus on the performance of emerging bond markets in the 1990s, using the "EMBI" and "EMBI+" return indices constructed by $\mathrm{J}$ P Morgan. In terms of both the asset class and the time period covered, these papers are narrower than the present study, and they are not primarily interested in tracking returns in crisis times (aggregate return indices such as the EMBI or EMBI+ are arguably not well suited to that purpose). ${ }^{3}$ However, the use of monthly return data as opposed to annual data

2 See Lindert (1989), appendix B.

3 The EMBI and EMBI+ reflect a weighted average of returns on liquid traded instruments. The composition of the indices is revised every month. During debt restructuring episodes, there can be particularly large compositional shifts. For example, as a result of the Argentine debt crisis and the debt swaps that took place during 2001, the face value of Argentine debt tracked in the EMBI+ fell from about US\$ 41bn at end 2000 to about US\$13bn, and the 2001 index contains less than half of the Argentine instruments that were in the 2000 index. Since changes in the value of the index reflect both price effects and composition effects and these are correlated, the aggregate EMBI and EMBI+ indices will tend to understate investor losses in a crisis. 
allows them to undertake some empirical work that is beyond the scope of this paper, such as analyzing the shifting correlation of emerging market bond returns with the returns of other asset classes, such as emerging market equities, high-yield corporate bonds and the U.S. stock market.

Third, major investment banks such as J. P. Morgan or Merrill Lynch regularly perform analyses of emerging market debt as an asset class. These are typically not published, but available to clients and newsletter subscribers. Like the literature on emerging market bonds described earlier, they are based on comparing bond indices compiled since the early 1990s to total return indices of other asset classes in terms of returns, volatility, and covariances. As far as the 1990s are concerned, the main results obtained in these studies are quite close to those obtained in this paper (see Section IV.C and IV. D below), in spite of the differences in methodology. The main dimension in which we extend these studies is that investment banks focus on bond returns in the post Brady deal period, while our study tracks the performance of all privately held external debt since the mid-1980s - after secondary market loan prices become available — and includes results for the 1970-2000 period as whole.

Fourth, there is related work in empirical corporate finance, most notably a recent paper by Elton, Gruber, Agrawal and Mann (2001), which decomposes the observed ex ante spread between corporate and government bond rates in the United States into an expected default premium, a premium related to differences in taxation, and a residual, which is interpreted as a true economic risk premium. Their main result is that the portion of the ex ante spread that is explained by expected default loss is small, while the economic risk premium is substantial. They also find that this premium is significantly related to the same factors which are used to account for risk premia in stock markets in the empirical finance literature. While using a different methodology, we follow analogous steps in this paper by looking at the extent to which a spread remains after taking into account defaults on emerging market debt, and looking at the co-movements of ex post returns with the returns on other asset classes.

Finally, there is some recent work on rates of return on external assets and liabilities in industrial countries, using balance of payments data (BOP) and data about international investment positions (IIP). Lane and Milesi-Ferretti (2002) estimate average returns on assets and liabilities of 20 countries for the 1983-1998 period. Lane and Milesi-Ferretti (2003) distinguish between returns on equity, FDI and debt holdings on both asset and liability sides, and examine their correlations with the corresponding market return measures (e.g., stock market returns for equity holding, or OECD interest rates for debt holdings). The main difference with respect to this paper is that we are concerned only with rates of return on privately held emerging market debt, which accounts only for a small fraction of industrial country investment positions. ${ }^{4}$

\footnotetext{
${ }^{4}$ In principle, BOP/IIP data could be used to extend Lane and Milesi-Ferretti's approach to emerging market countries. However, a further breakdown of debt returns into different creditor or debtor categories (e.g. looking just at how private investors fared with emerging market sovereign debt) is typically not available from balance of payments statistics.
} 


\section{Methodology And Data}

The basic approach of this paper is to compute internal rates of return from payment flows between private creditors and emerging market debtor countries, applying the same methodology as in the evaluation of an investment project. There are two complications, however. The first is the mundane but non-trivial issue of constructing an appropriate debt flow series based on World Bank debt data. As first noted by Peter Lindert (1989), it would be incorrect for our purposes to use the published $G D F$ flow data directly, for reasons that have to do with the impact of debt restructuring operations that involve exchanges of instruments across asset classes, as well as measurement error. ${ }^{5}$

The second complication is that the investment project analogy itself does not hold perfectly. There is no "final repayment" at the end of our sample period. Instead, investors own an outstanding debt stock, i.e., a claim to (uncertain) future principal and interest payments. Similarly, in the first sample year, investors start out owning a positive debt stock rather than making an initial disbursement. The latter is not a big problem for computing rates of return over the entire sample period (1970-2000), since the initial debt stock was tiny relative to the disbursements that followed. But it is a problem if we want to compute returns over sub periods, say, for 1990-2000. A potential solution is to value both the first period and endperiod debt stock at secondary market prices, i.e. to compute returns as if investors had bought debt in the market at the beginning of the period, received net flows, and finally sold their end-period holdings at market prices. However, secondary market debt prices are only available for some instruments and some countries and not available at all prior to 1986, so this approach requires some assumptions. In addition, to the extent that we choose our sample of countries based on the availability of secondary market prices at the end of the period, we are exposed to possible "survival bias," as countries that performed very poorly may have disappeared from the debt market.

We discuss our approach to these problems in turn. In addition, we briefly describe our methodology for computing an alternative rate of return on U.S. debt instruments that we use as a benchmark to compare our results.

\section{A. Measuring Net Transfers Between Creditors and Debtors}

Data on actual "net transfers"- - defined as disbursements minus the sum of interest payments and principal repayments-is directly available from the World Bank's $G D F$ database for a variety of external debt types (total, long term, long term public and publicly guaranteed, and

\footnotetext{
${ }^{5}$ The nature of the data problem and the necessary adjustments are somewhat different from what was assumed by earlier authors. Lindert (1989) and Klingen (1994) overstate the extent to which the GDF's "net transfers" concept needs to be adjusted, while placing too little emphasis on how to deal with stock-flow discrepancies that are due to measurement error. See Appendix I for details.
} 
long term private non-guaranteed debt) and creditor classes (official and private, plus some subcategories). This concept is already very close to what we need. Not only will it capture standard disbursements and debt service, but-with one important exception that will be discussed below_-debt restructuring operations will be reflected exactly as one would want. For example, debt stock write-offs (or rescheduling) of principal will lead to correspondingly lower (or later) principal repayments, and thus be reflected in a lower internal rate of return. Moreover, the $G D F$ employs appropriately broad payments concepts. To name two important examples that have caused confusion in the past, cash payments associated with debt buy back operations are regarded as "principal repayments" and are thus included in net transfers on long term debt. So is the clearance of interest arrears on long term debt (even though accumulated interest arrears themselves are regarded as short term debt).

The only major problem with using $G D F$ net transfer data directly has to do with debt consolidation or restructuring operations that involve exchanges of instruments across asset classes. In that case, the $G D F$ will record a stock operation in one debt category, but the counterpart operation will be recorded either in a different debt category, or not at all if the other asset is not debt (as in the case of debt-equity swaps). In the event of a stock reduction operation in the original debt class, this would lead us to underestimate investor returns. As in the case of a pure cancellation of claims, we would see debt stocks and subsequent payments decline in the category which we are tracking, ignoring the fact that investors may in fact have been compensated by obtaining new claims in a different asset class. Conversely, if we were tracking returns in the latter, these would be overestimated. For example:

- In the case of debt-equity swaps, the $G D F$ will record a decline in the debt stock as well as in the subsequent debt service, but no repayment, since no cash repayment occurs. From the investor perspective, however, the receipt of equities constitutes a claim on a new payments stream; ignoring this claim would lead us to underestimate the return on debt.

- In the case of a consolidation of short term debt into long term debt (as occurred during the 1980s debt crisis), short term debt will decline without a repayment while long term debt-and future debt service on long term debt—will increase without any disbursement. Long term debt flows will thus lead to an overestimation of the rate of return on long term debt, while short term debt flows will lead to an underestimation of the return on short term debt.

- In the case of an exchange of loans for bonds (as occurred in the context of the Brady deals) we would see the loan stock and subsequent debt service on loans decline without a repayment, while the bond stock increases without a disbursement, leading to the underestimation of returns on loans and overestimation of returns on bonds if reported net transfers are used mechanically within each category.

In principle, the solution to the problem of debt exchanges across asset classes is simple: we must explicitly record such transactions as quasi-repayments or disbursements. In other 
words, we must construct a modified net transfer series $n t r *$ (defined from the perspective of creditors):

$$
n t r^{*}=-n t r+d e s+x
$$

where $n t r$ are net transfers from the debtor perspective as recorded in the $G D F$, des stands for the market value of debt swapped for equity and $x$ is the sum of quasi-repayments (entering with a positive sign) and quasi-disbursements (entering with a negative sign) attributable to any operation involving stock adjustments across debt categories.

What $x$ precisely contains will depend on the debt category on which we are focusing. The more specific the category, the more cross-category restructurings we may have to account for. For example, if we are interested in total debt, then the only transaction we need to add to $-n t r$ is debt-equity swaps as a quasi-repayment; thus $x=0$. If we are interested in privately held long term debt, then $x=-s c$, the increase in the long term debt stock resulting from short term debt consolidation (a quasi-disbursement). If we focus on privately held long term public and publicly guaranteed debt, we may in addition have to worry about conversions of private non-guaranteed debt into public debt, and so forth.

The approach taken in this paper is to focus mainly on broad debt categories to keep the accounting for cross-category restructurings relatively manageable. However, we stop short of computing rates of return on total external debt, which would include short term debt, for several reasons. First, virtually all emerging market debt traded in secondary markets has an original maturity of more than one year, and is thus classified as long term by the World Bank; second, except for interest arrears, the $G D F$ does not break down short term debt by public and private creditors, third, the World Bank's debtor reporting system, in which debt is reported by debtor country officials on an annual basis, is not considered a very reliable source for short term-mostly privately issued-debt. Accordingly, most of the focus of the paper is on privately held long term debt (both public and publicly guaranteed, and private non-guaranteed), and privately held public and publicly guaranteed debt only, i.e., essentially sovereign debt held by private creditors.

The question is how to measure $x$ for these debt concepts. There are two ways: either by attempting to measure its components directly, or by "backing it out" from changes in the debt stock, as first suggested by Lindert (1989). We refer to the former as the "direct approach" and the latter as the "indirect approach." As it turns out, the World Bank maintains and kindly supplied us with data on both debt-equity swaps and short term debt

consolidations, ${ }^{6}$ so in this paper, the direct approach is feasible at least for our broadest debt category, namely privately held long term debt. In this case, $n t r^{*}=-n t r+d e s-s c$.

${ }^{6}$ Debt-equity swaps are a sub item of "debt stock reduction", which is shown in the aggregate (for total debt) in Section 7 of the published GDF country tables. Short term debt consolidation is not explicitly shown in the published $G D F$, although it can generally be 
The indirect approach is based on the following identity, which relates debt stocks to flows: ${ }^{7}$

$$
\Delta D=d-r-d f r+c c v+i c-x+u
$$

where $x$ is the placeholder for net cross-category debt restructurings other than debt-equity swaps, $\Delta D$ denotes the measured change in the long term debt stock (in U.S. dollars) for the relevant creditor class, $d$ denotes (recorded) disbursements and $r$ denotes (recorded) principal repayments. $d f r$ stands for "debt forgiveness or reduction" and describes a reduction in the face value of the debt stock through any operation other than principal repayments (including cash payments associated with buybacks, which are also recorded as repayments). $c c v$ (cross-currency valuation) denotes changes in measured dollar debt stocks as a result of any movements in the exchange rate between the currency of debt denomination and the US dollar, ic denotes interest and interest arrears capitalized, and $u$ denotes a residual attributable to measurement error in any of the categories in the identity. All items in equation (2) except for $x$ and $u$ are observable. ${ }^{8}$ In principle, $u$ should be zero. In that case, $x$ can be computed as the residual in equation (2).

In this paper, we apply both the direct and indirect approach for the two broadest debt categories. In the absence of any measurement error $u$, they should give us identical results. In practice, $u$ is different from zero, and the results yielded by the two approaches can be far apart for some countries and time periods, but the estimated long-run rates of return-and overall conclusions-will not depend on which method is chosen. Nonetheless, it is worth asking which method is more reliable. The answer depends on what generates the residual. If the measurement error is mostly in reported net flows $d-r$, and $x$ as recorded directly by the debtor reporting system, then the direct approach would mismeasure $n t^{*}$, and we would be advised to go with the indirect method. If, on the other hand, we are mainly mismeasuring the adjustments $d f r, c c v$, and $i c$ that need to be made to implement the indirect approach, then the direct method would be preferable.

backed out as a residual by subtracting changes in the short term debt stock from net flows on short term debt (see line "of which: short term debt", below "Net flows on debt" in Section 1 of the published $G D F$ ) and adding "net change in interest arrears" (Section 8 of the published $G D F)$. See Appendix I.

7 This identity closely resembles the debt stock-flow reconciliation presented in Section 8 of the print version of the GDF. Appendix I explains how the two are related.

${ }^{8}$ The World Bank maintains data on debt stock reductions, debt forgiveness, interest capitalization and cross-currency valuation for various debt and creditor classes. At the most aggregate level (total debt), these are available in the public database. Disaggregated data, which we used to construct the concepts on the right hand side of equation (2) at exactly the level of aggregation at which we need it (namely, for privately held sovereign debt and all privately held debt) was kindly provided to us by the Bank. 
We asked our colleagues at the World Bank's Financial Data Group, who maintains the debt data used in this paper, to interpret the major residuals we found, i.e., the discrepancy between $x$ as reported directly and $x$ as inferred from (2). While the residuals often have idiosyncratic "causes", there appear to be a few systematic sources of error. In general, these will be filtered out by the "indirect method" but not the direct method. First, the Bank's debtor reporting system's data on short term debt consolidation (one of the variables in $x$ ) is not very reliable for the 1980s - when many of these restructuring took place - and is in fact not published for that reason. Perhaps more importantly, the countries examined in this paper occasionally "discovered" previously unrecorded debt in the context of a debt crisis or a debt restructuring agreement, and sometimes broadened the definition of external debt covered in the $G D F$ (for example, to include state and provincial debt in addition to central government debt). In these cases, the debt stock would be adjusted upward, generally without recording a corresponding disbursement. ${ }^{9}$ Since subsequent repayments and interest payments are related to the new debt stock, the reported net flows need to be adjusted by a "quasi-disbursement" to avoid exaggerating the rate of return. This is exactly what the indirect approach achieves, since it adds the unexplained change in the debt stock to recorded net flows.

This said, not all potential sources of error favor the "indirect approach." In particular, the World Bank makes cross-currency valuation adjustments only for public and publicly guaranteed (PPG) debt, but not for private non-guaranteed (PNG) debt, which is included in the broader of the two debt concepts we look at. Moreover, it turns out that the Bank's $c c v$ series for PPG debt is an exact measure of cross-currency valuation changes only if endperiod and average exchange rate are the same. To the extent that they differ, this will introduce a residual in the stock-flow reconciliation and an error in net transfers computed through the indirect approach (see Appendix I for details). Finally, the indirect approach could introduce errors through the mismeasurement of debt reduction. While we believe that the indirect method is generally more trustworthy, there are thus reasons to look at the results from both sides. As we shall see, the choice of method can substantially affect the results for a few individual countries and over shorter time periods; however, it is not critical to the overall findings of the paper.

\section{B. Valuing Debt Stocks and Addressing Survival Bias}

Valuing the debt stock is conceptually simple: we take the outstanding stock of privately held long term debt (in case of the final period, inclusive of interest arrears) ${ }^{10}$ and multiply the result with a weighted average of secondary market debt prices. This average is computed over all debt issues for which prices are available, using the face value outstanding of each

\footnotetext{
${ }^{9}$ The flow counterpart of the higher debt are unrecorded net disbursements in the past. While the Bank attempts to adjust past flows if there is new information on the timing and level of past disbursements, this is often lacking, and in that case no flow adjustments will take place. ${ }^{10}$ Interest arrears on long term debt constitute a claim on future long term debt flows, but are classified as short term debt in the GDF. They thus need to be added to long term debt.
} 
instrument to compute the weight. For the mid 1990 until 2000, we mainly use instrumentlevel prices underlying J.P. Morgan's "EMBI Global” bond index. For the late 1980s and early 1990s, we mainly use representative, country specific secondary market loan prices that are available for the pre-Brady deal period. Sources, calculations and resulting prices series are described in detail in Appendix II.

In practice, there are three complicating factors. First, no secondary market price data is available prior to 1986, preventing us from computing rates of return for any subsample that begins before that year. For the purposes of computing rates of return for the entire sample 1970-2000, debt outstanding in 1970 is valued at par, i.e. we assume that the face value of the debt in 1970 equals its market value. To the extent that the outstanding debt in 1970 was actually worth less, this implies that our results for the long-run rate of return may slightly understate the true ex post rate of return. However, any bias would be minimal. First, end1970 developing country debt held by private creditors was tiny relative to the flows that followed (developing country sovereign debt held by private creditors increased almost twenty-fold between 1970 and 1982). Second, any market discount would have been small, since 1970 precedes the first episodes of debt distress involving developing countries and private creditors (Zaïre and Peru in the mid-1970s) by several years.

Second, we must assume that debt prices available for the period after 1986 are representative. While this is unproblematic "within" the loans and bonds debt classes, it is less clear whether bond prices carry over to bank loans and vice versa. Whether or not this creates a bias depends on whether the terms of the instruments for which we do and do not have prices are similar, and of course on the relative size of the debt class for which we have prices. Appendix II shows that the issues for which prices are available generally represent a substantial share of the total debt stock, but there are exceptions for some countries and time periods.

Third, among the countries for which GDF data is available since 1970, we only have end2000 debt prices for 22 countries: Algeria, Argentina, Brazil, Chile, Colombia, Côte d'Ivoire, Ecuador, Indonesia, Jordan, Korea, Lebanon, Malaysia, Mexico, Morocco, Nigeria, Pakistan, Panama, Peru, Philippines, Thailand, Turkey and Venezuela. If we allow this set to define our sample, our aggregate results - pooling debt flows to these countries-may display "survival bias." Some countries may no longer be traded on the secondary debt market on the grounds that they were poor performers, from an investor perspective. Indeed, this was true for several countries - including Bolivia, Sudan, the Republic of Congo, and the Democratic Republic of Congo (Zaïre)—in the early 1990s.

To deal with this problem, we take the following approach. First, we present results for the 2000 sample without addressing survival bias. We then show results for a sample of countries defined by the existence of secondary market debt prices in 1991, assuming a zero 2000 price for the countries for which no secondary market price existed in 2000. Before 1992, a presence in the secondary debt market was not a sign of "survivorship". The secondary market was created during the 1980s to trade loans to countries that had large stocks of debt outstanding and had run into debt service troubles in the course of the 1980s. 
By 1991, no country had yet "dropped out" of this market (the first to do so was Bolivia in 1993). Thus, allowing the existence of secondary market debt prices in 1991 define our sample does not create an upward bias to returns--if anything, in might create a downward bias. Furthermore, assuming that the debt of the countries that dropped out of the sample was worth nothing in 2000 is of course an exaggeration. Consequently, the rate of return computed under this assumption is a lower bound for the true rate of return in the 1991 sample, and the difference between this rate of return and the one of the 2000 sample represents an upper bound for the survival bias that might be distorting our results.

\section{Computing Rates of Return for Alternative Assets}

In order to decide whether our results should be considered high or low, we need to know what investors would have earned if they had purchased alternative assets in the same period. The most basic comparison is with the return on a debt instrument of similar duration but without default risk, such as a U.S. government bond, but we also consider risky assets such as U.S. corporate or high-yield bonds, and equities.

A first challenge is to make an educated guess about the average duration of emerging market debt in the 1970-2000 period. According to World Bank data, the average maturity of emerging market debt in our sample was about 10 years. However, a large fraction-in our sample, about 50 percent in the 1970s, rising to two-thirds in the early 1980s before falling back to about 50 percent in the 1990s - carried a floating interest rate (typically defined as a mark-up over the six month LIBOR, and reset semiannually). For this type of debt, most international interest rate risk is assumed by the borrower, while the value of the debt is largely invariant to interest rate changes. "Effective duration"- the sensitivity of the debt price to a parallel shift in the yield curve-is about zero. Average effective duration must thus lie somewhere between 6 months and 10 years. While we have no data on average duration of all private lending throughout the sample period, this range can be narrowed by considering the average duration of the debt instruments in the EMBIG, the broadest emerging market bond index, computed by J. P. Morgan since 1993 (Table 1).

Table 1. Average Duration of EMBIG Debt in Our Sample

\begin{tabular}{llrrrrrrrrr}
\hline & 1993 & 1994 & 1995 & 1996 & 1997 & 1998 & 1999 & 2000 \\
\hline Percent of EMBIG covered by sample (FV) & $\underline{1}$ / & 69 & 85 & 87 & 86 & 78 & 76 & 76 & 79 \\
Percent of EMBIG covered by sample (Mkt. Cap.) & $\underline{2} /$ & 76 & 88 & 88 & 86 & 80 & 87 & 85 & 84 \\
Percent of sample covered by EMBIG (FV) & $\underline{3} /$ & 34 & 46 & 47 & 47 & 47 & 43 & 44 & 45 \\
Average duration (in years) & & 3.8 & 3.0 & 4.1 & 3.8 & 3.6 & 4.2 & 4.0 & 4.2 \\
\hline
\end{tabular}

Sources: J.P. Morgan; authors' calculations.

$\underline{1}$ / Face value of intersection of EMBIG and our sample as a percentage of face value of EMBIG.

2/ Market value of intersection of EMBIG and our sample as a percentage of market value of EMBIG.

3/ Face value of intersection of EMBIG and our sample devided by face value of our sample (privately held public and publicly guaranteed debt outstanding). 
Table 1 shows that our sample covered over 85 percent of the EMBI in the mid 1990s, i.e, the EMBIG countries that are not in our sample - transition economies and South Africa, for which no GDF data is available until the 1990s-made up less than 15 percent. By 2000, this fraction had gone up to just over 20 percent. Conversely, since 1994 close to half of the debt owed by our sample of countries was tracked in the EMBIG (in essence, all liquid international bonds with at least 1 years remaining maturity). The average duration of this debt was between 3 and 4.2 years. Since we know that the fraction of floating rate debt was higher in the 1980s and in the 1970s and 1990s, we take the bottom of this range as a best guess for the average duration over the whole period.

Another challenge is to match the time pattern of disbursements and repayments under an alternative investment assumption with that of actual debt flows to emerging markets. Consider, for example, returns over the entire period: If most flows to emerging markets had occurred in the 70s and early 80s, when U.S. inflation and government bond yields were relatively high, we would need to give more weight to this period when computing the alternative return. Computing average annual returns based on a return index, for example, could be misleading. This would deliver the average return of a fixed initial investment held over the entire period. In contrast, the return on emerging market debt that we compute from 1970 to 2000 is based on a specific time path of inflows and outflows.

We thus compute alternative returns assuming that disbursements to emerging market countries had instead been used to purchase the alternative asset (see Appendix III for details). In the case of U.S. government bonds, we construct a relevant stream of flows using annual yields and assuming that the bond is held to maturity. In the case of alternative investments where a return index is available, we construct net transfers using annual returns, as if disbursements to emerging markets had been redirected to purchase an instrument of one year maturity. Internal rates of return are then computed for these artificial flows.

\section{RESUlts}

\section{A. Alternative Estimates of Net Transfers}

As explained in the previous section, this paper focuses on a set of 22 emerging market countries defined by the availability of debt data since 1970 and secondary market debt prices in 2000. For the reasons explained, we concentrate on privately held debt with original maturity of at least one year, including both public and publicly guaranteed debt (PPG) and private non-guaranteed debt (PNG). Figure 1 gives a sense of the quantitative significance of this debt over time, relative to both the total (short and long term) privately held debt of the 22 countries, and relative to the aggregate privately held debt of all countries reported in the $G D F$.

Figure 1 shows that the 22-country emerging market group accounts for most privately held developing country debt. Its share stood at around 80 percent in the 1970 s, fell to about 70 percent in the mid-1980s and to about 60 percent in the early 1990s (a phenomenon partly 
accounted for by debt flows to transition economies, which are not part of our group of countries since they did not report external debt until the 1980s or 1990s). After that, the share rose again and is currently at about 65 percent. In relation to liquid emerging market debt, the share of our 22-country sample was higher, making up about 80 percent of JP Morgan's EMBIG - the broadest emerging market index - in terms of face value, and about 85 percent in terms of market capitalization in 2000 (Table 1). Figure 1 also shows that debt classified as long term makes up a high share of privately held external debt in these 22 countries, between 65 and 85 percent (this assumes that short term debt was all privately held, otherwise the share would be even higher). At end-2000, it stood at 79 percent.

Figure 1. External Debt of Developing Countries, 1970-2000

(in billions of U.S. dollars)

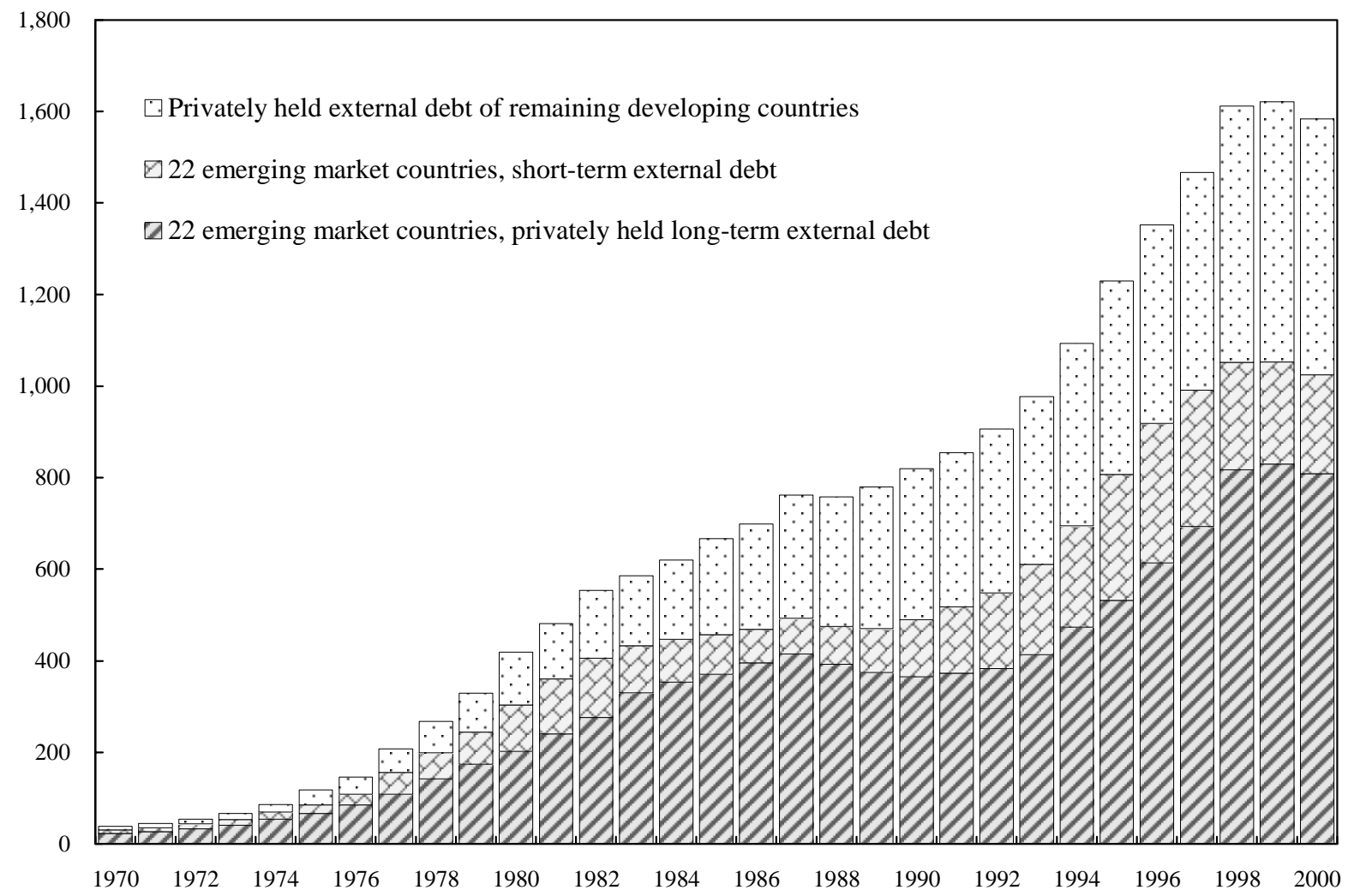

Source: Global Development Finance database.

For each country, we study four different series of net transfers on long term debt: a broad concept that includes private credit to both official and private debtors, and a narrower concept that includes only sovereign debt owed to private creditors, ${ }^{11}$ using the "indirect" and

${ }^{11}$ In GDF terminology, the former is based on the sum of "PPG, private creditors" and "PNG" in its entirety, while the latter only includes "PPG, private creditors". Throughout the paper, we use "public and publicly guaranteed debt" and "sovereign debt" synonymously. 
"direct" methodologies in each case (Table 2). There are some trade-offs between using these four concepts. The indirect method has the advantage that one does not have to worry about reclassifications between private and sovereign debt, or make assumptions on whether short term debt consolidation affected only sovereign debt or also privately issued debt.

Alternatively, these problems could be avoided by using the broad debt concept that includes both types of debt. However, since the $G D F$ data is based on information supplied by public officials in the debtor country, the narrower concept which excludes privately issued debt is probably reported more reliably.

Table 2. Comparison of Assumptions

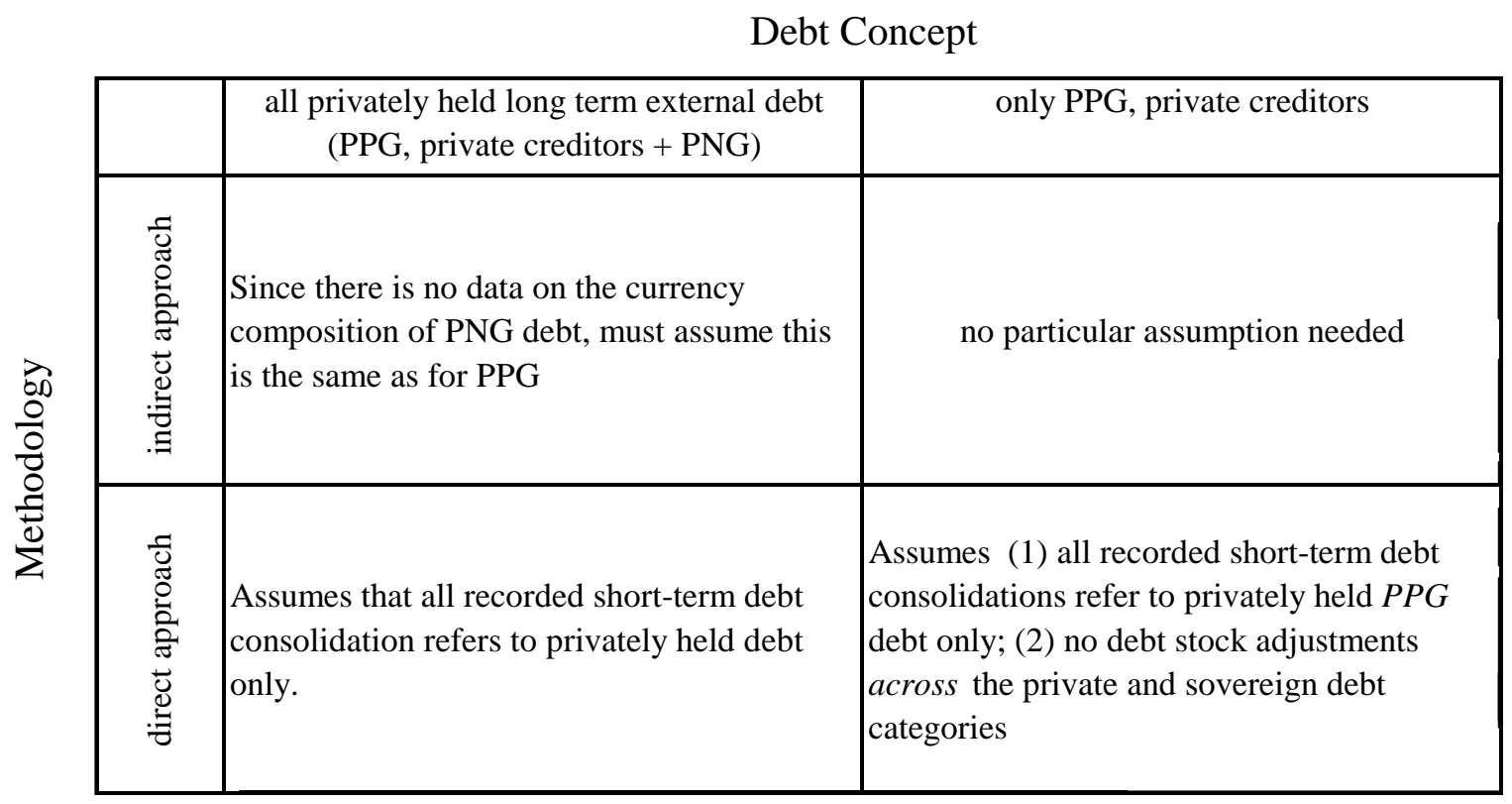

Figure 2 plots the four series from 1971 until 2000 from the debtor country perspective (positive numbers represent transfers to the debtor). While the series are obviously highly correlated, there substantial discrepancies between the indirect and the direct approaches in some years (for example, in 1983-this reflects newly "discovered" debt, which is treated as a disbursement in this year under the indirect approach, but not under the direct approach). Another interesting point to note is the widening gap between all privately held long term debt flows and PPG debt during the 1990s. This reflects the growing importance of private nonguaranteed debt. Finally, note the strong cyclicality of flows. There are two clear boombust cycles. The first builds up during the mid 1970s, followed by a collapse of net flows from 1983-84 until the late 1980s. The trough of the cycle according to net flows is in 1988 or 1989; as we shall see, this coincides with the trough in secondary market debt prices. We then enter a long boom from 1989 until 1998, followed by a much sharper collapse than in the previous decade. 
Figure 2. Net Transfers on Debt to 22 Emerging Market Countries, 1970-1990 (In billions of US dollars)

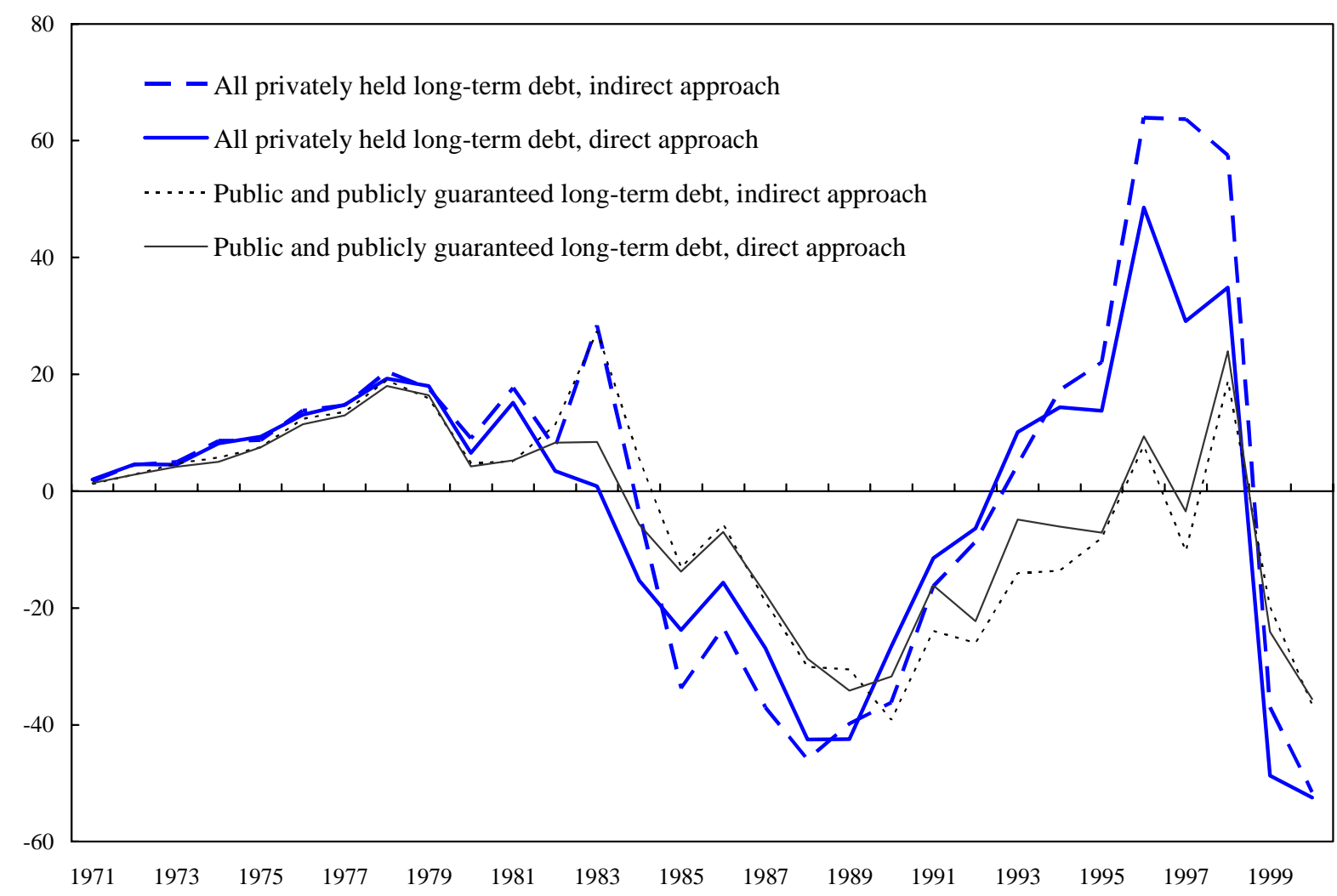

Source: Authors' calculations based on $G D F$ database.

\section{B. Long-Run Debt Returns, 1970-2000}

Table 3 shows internal rates of return on debt for each of the four net transfer series, augmented by an initial "disbursement" equal to the debt stock in 1970, and a final "repayment" equal to the value of the debt stock at market prices in 2000. We also show the returns that investors would have earned if the same initial disbursement and subsequent net disbursements had instead been invested in the three alternative assets: 3 year U.S. treasury zero coupon bonds, 10 year U.S. treasury zero coupon bonds and a U.S. corporate bond index. Based on the average duration of the data (Section III.C), the 3 year U.S. bond is the most appropriate default-risk comparator; however, since the 10 year U.S. bond is a much more common benchmark, we show that too. Alternative returns based on U.S. corporate bond returns are shown to help us decide whether ex post risk premia—if any-should be considered large or not. In Section D below, we extend the comparison by also looking at U.S. high-yield bonds and equity market returns. Note that since the disbursement paths differ across debt concepts, methodologies and countries, so will the alternative returns for each asset class. 
Table 3. Countries with Secondary-Market Prices in 2000: Ex Post Returns to Private Creditors, 1970-2000

\begin{tabular}{|c|c|c|c|c|c|c|c|c|c|c|c|c|c|c|c|c|}
\hline & \multicolumn{8}{|c|}{ all long term debt flows } & \multicolumn{8}{|c|}{ flows of public and publicly guaranteed debt } \\
\hline & \multicolumn{4}{|c|}{ indirect approach } & \multicolumn{4}{|c|}{ direct approach } & \multicolumn{4}{|c|}{ indirect approach } & \multicolumn{4}{|c|}{ direct approach } \\
\hline & actual & US3y & US10y & UScb & $1 / \overline{\text { actual }}$ & US3y & US10y & UScb & $1 / \overline{\text { actual }}$ & US3y & US10y & UScb & $1 / \overline{\text { actual }}$ & US3y & US10y & UScb \\
\hline All countries & 8.4 & 8.4 & 9.1 & 10.4 & 9.3 & 8.6 & 9.0 & 10.4 & 8.5 & 8.7 & 9.3 & 10.6 & 9.1 & 8.6 & 9.2 & 10.5 \\
\hline Latin America & 8.5 & 8.5 & 9.2 & 10.5 & 9.5 & 8.7 & 9.1 & 10.4 & 8.3 & 8.7 & 9.4 & 10.7 & 9.5 & 8.7 & 9.2 & 10.5 \\
\hline Argentina & 7.2 & 8.4 & 9.3 & 10.7 & 8.5 & 8.6 & 9.4 & 11.1 & 7.3 & 8.3 & 9.2 & 10.7 & 11.8 & 8.3 & 8.8 & 10.1 \\
\hline Brazil & 8.5 & 8.6 & 8.9 & 10.1 & 9.2 & 8.6 & 8.8 & 9.8 & 8.5 & 8.9 & 9.4 & 10.6 & 7.7 & 8.7 & 9.3 & 10.5 \\
\hline Chile & 9.5 & 8.9 & 9.8 & 11.3 & 9.7 & 9.4 & 9.9 & 11.5 & 9.0 & 9.0 & 10.1 & 10.6 & 12.6 & 9.5 & 10.3 & 10.7 \\
\hline Colombia & 8.5 & 7.9 & 8.9 & 10.2 & 8.6 & 8.2 & 9.3 & 10.8 & 8.0 & 8.2 & 9.1 & 10.7 & 8.1 & 8.2 & 9.1 & 10.7 \\
\hline Ecuador & 4.5 & 8.7 & 9.4 & 11.1 & 4.5 & 8.7 & 9.3 & 11.2 & 4.0 & 8.4 & 9.4 & 11.2 & 6.4 & 8.5 & 9.4 & 11.2 \\
\hline Mexico & 9.6 & 8.5 & 9.3 & 10.8 & 11.0 & 8.9 & 9.3 & 10.8 & 9.3 & 8.7 & 9.5 & 10.9 & 10.4 & 8.7 & 9.4 & 10.8 \\
\hline Panama & 8.0 & 8.6 & 8.6 & 9.9 & 9.0 & 8.7 & 8.6 & 9.9 & 8.1 & 8.7 & 8.6 & 9.9 & 9.1 & 8.7 & 8.7 & 9.9 \\
\hline Peru & 6.0 & 8.3 & 8.8 & 9.1 & 2.5 & 8.4 & 9.1 & 10.0 & 6.2 & 8.8 & 9.2 & 10.2 & 3.7 & 8.5 & 9.2 & 10.1 \\
\hline Venezuela, R. & 7.6 & 8.7 & 9.2 & 10.8 & 13.1 & 9.0 & 8.6 & 10.5 & 7.9 & 8.5 & 8.9 & 10.5 & 11.5 & 8.5 & 8.6 & 10.4 \\
\hline Emerging Asia & 8.7 & 8.1 & 8.9 & 10.0 & 9.8 & 8.4 & 9.3 & 10.3 & 9.5 & 8.8 & 9.5 & 10.6 & 9.5 & 8.7 & 9.5 & 10.6 \\
\hline Indonesia & 8.4 & 7.8 & 8.6 & 9.6 & 11.2 & 8.4 & 9.3 & 9.9 & 10.0 & 8.7 & 9.4 & 10.3 & 11.1 & 8.9 & 9.6 & 10.4 \\
\hline Korea, Rep. o & 9.6 & 8.3 & 9.0 & 10.1 & 9.1 & 8.3 & 8.9 & 10.0 & 9.8 & 8.8 & 9.3 & 10.1 & 8.6 & 8.6 & 9.1 & 10.0 \\
\hline Malaysia & 8.8 & 8.6 & 10.0 & 11.3 & 8.6 & 8.7 & 10.1 & 11.3 & 9.5 & 9.1 & 10.6 & 11.9 & 10.8 & 9.3 & 10.8 & 12.0 \\
\hline Philippines & 6.9 & 8.4 & 8.7 & 10.0 & 6.4 & 8.3 & 8.5 & 10.1 & 7.0 & 8.5 & 8.8 & 10.6 & 5.8 & 8.4 & 8.8 & 10.5 \\
\hline Thailand & 8.9 & 7.3 & 8.5 & 9.4 & 12.0 & 8.0 & 10.0 & 10.7 & 10.8 & 8.8 & 9.6 & 11.3 & 10.7 & 8.8 & 9.6 & 11.3 \\
\hline Other emerging & 7.6 & 8.4 & 8.7 & 10.5 & 7.6 & 8.4 & 8.6 & 10.3 & 8.0 & 8.6 & 8.8 & 10.5 & 7.0 & 8.4 & 8.7 & 10.4 \\
\hline Algeria & 8.6 & 8.9 & 8.4 & 9.9 & 7.1 & 8.7 & 8.3 & 9.8 & 8.6 & 8.9 & 8.4 & 9.9 & 7.1 & 8.7 & 8.3 & 9.8 \\
\hline Côte d'Ivoire & 4.6 & 9.3 & 10.0 & 11.7 & 8.2 & 9.6 & 9.4 & 10.8 & 4.0 & 9.3 & 9.4 & 10.9 & 1.2 & 9.1 & 9.4 & 10.9 \\
\hline Jordan & 6.0 & 8.1 & 9.1 & 10.7 & 3.2 & 7.8 & 8.9 & 10.4 & 6.0 & 8.1 & 9.1 & 10.7 & 3.2 & 7.8 & 8.9 & 10.4 \\
\hline Lebanon & 7.0 & 6.4 & 6.6 & 8.3 & 6.5 & 6.4 & 6.7 & 8.3 & 7.0 & 6.5 & 6.6 & 8.8 & 6.2 & 6.5 & 6.6 & 8.7 \\
\hline Morocco & 8.9 & 8.9 & 8.8 & 10.3 & 5.7 & 8.6 & 8.8 & 10.3 & 9.2 & 9.0 & 8.9 & 10.4 & 5.6 & 8.6 & 8.8 & 10.3 \\
\hline Nigeria & 7.6 & 9.5 & 10.7 & 12.6 & -0.2 & 8.5 & 9.8 & 12.0 & 7.7 & 9.4 & 10.6 & 12.5 & 0.0 & 8.4 & 9.8 & 11.9 \\
\hline Pakistan & 4.6 & 7.6 & 8.7 & 9.0 & 4.6 & 7.8 & 9.0 & 9.2 & 4.9 & 8.1 & 9.2 & 9.4 & 3.6 & 8.1 & 9.1 & 9.5 \\
\hline Turkey & 6.7 & 7.2 & 7.7 & 9.6 & 12.8 & 7.4 & 7.6 & 9.9 & 7.6 & 7.5 & 8.1 & 10.2 & 12.7 & 7.6 & 7.9 & 10.2 \\
\hline
\end{tabular}

Sources: For rates of return data for alternative assets: Board of Governors of the Federal Reserve System, Merrill Lynch; authors' calculations.

1/ "US3y","US10y" and "UScb" stand for comparable returns on 3 year and 10 year U.S. treasuries, and U.S. corporate bonds, respectively. 
The main finding of Table 3 is that for aggregate debt flows, returns from 1970 to 2000 have been about the same or slightly higher than returns on 3 year U.S. treasury bonds, about the same or slightly lower than returns on 10 year U.S. treasury bonds, and about 100-200 basis points lower than the return on U.S. corporate bonds. While estimated returns tend to be a little higher for the "direct" method, this is true regardless of which method is used, and regardless of whether one focuses on all debt or just sovereign debt. Thus, average ex post risk premia from 1970-2000 have been close to zero-smaller than the risk premia earned by U.S. corporate bonds. This seems surprising given the fact that corporate bonds are investment grade, while most emerging market debt was not.

For most borrowers, these findings apply even country by country. In Figure 3, we have plotted country-specific returns for PPG debt together with the corresponding returns on 3 year U.S. treasury bonds, in declining order of the spread between the two. We use a weighted average of the "indirect" and "direct" methods with weights 0.66 and 0.34 respectively, reflecting our relative degree of confidence in the two approaches.

Figure 3. Countries with Secondary Market Prices in 2000:

Average Returns and Ex Post Spreads for Public and Publicly Guaranteed Debt, 1970-2000 (in percent)

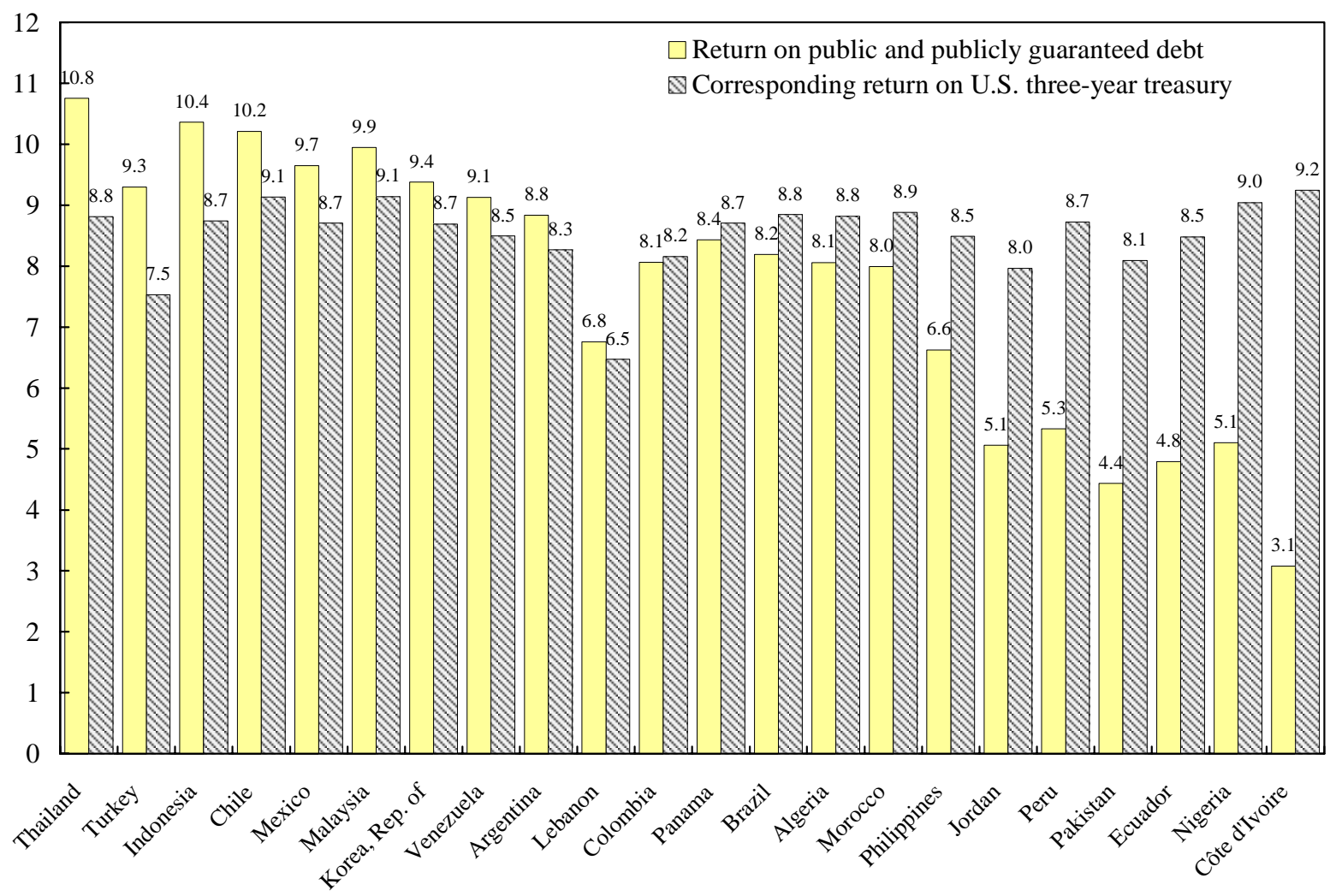

Source: Authors' calculations. 
Figure 3 shows that 11 out of 22 countries in our sample, accounting for 77 percent of the face value of debt in 1985 ( 74 percent in 2000) had average rates of return within 100 basis points of the corresponding return on a 3 year U.S. treasury bond. 15 out of 22 countries, making up 91 percent of the debt in 1985 and 95 percent in 2000, had average rates of return within 200 basis points of the corresponding U.S. treasury return. Of the six countries with large negative spreads toward the right, most are small debtors; only one of accounted for more than 2 percent of the privately held PPG debt stock, namely Nigeria (3.4 percent in 1985). Note that the precise ranking of ex post spreads in the figure depends on the weights placed on the "indirect" and "direct" results. However, the finding that most large debtors returned about the same as what investors could have earned on U.S. treasuries is not sensitive to these weights.

We now explore the robustness of these results, beginning with the issue of survival bias. We do this by re-computing aggregate rates of return for country groups defined by the availability of debt price data in 1991, assuming that the end-2000 value of the debt of countries that subsequently dropped out of the sample is zero. Because the latter is an excessive assumption, the return estimates that follow (Table 4) represent a lower bound, rather than a best guess. The sample underlying Table 4 contains 24 countries: Argentina, Bolivia, Brazil, Chile, Colombia, Ecuador, Mexico, Panama, Peru, Venezuela, Indonesia, Malaysia, Philippines, Thailand, Algeria, Democratic Republic of Congo, Republic of Congo, Cote d'Ivoire, Egypt, Jordan, Morocco, Nigeria, Sudan and Turkey. Thus, the 2000 sample equals the 1991 sample minus 5 countries that exited (Bolivia, Egypt, Democratic Republic of Congo, Republic of Congo and Sudan), ${ }^{12}$ plus 3 countries that entered (Korea, Pakistan and Lebanon). The upshot of Table 4 is that using the 1991 sample makes very little difference to the aggregate returns, which are only 20-30 basis points lower than in the sample defined by availability of price in 2000. This is because the countries that exited and entered the secondary debt markets between 1991 and 2000 accounted for a relatively small fraction of the total debt stock (about 2.6 and 4.4 percent, respectively, in terms of the 1991 debt stock). Only in the "other emerging" group do we see a difference (35-130 basis points, depending on which of the two methods is used), reflecting the fact that most countries that exited the sample, and two out of the three entrants, are members of this group.

Note that while the definition of the sample makes no big difference for the average level of returns, it has a stronger impact on the distribution of returns across countries. In the year in which we last observe a price (between 1992 and 1994), long run average sovereign debt returns for Bolivia, D.R. Congo, Republic of Congo and Sudan were 0.1, -1.5, 0.2 and -11.4 respectively (assuming a 0.66 weight on the "indirect" approach, as in Figure 1). This implies ex post spreads in the range of -8 to -20 percentage points. Thus, adding these countries to Figure 1 would significantly extend the tail of the distribution. However, the

${ }^{12}$ Egypt is a special case, in which we were able to find debt prices for most of the 1990s and 2001, but not for 2000 . 
statement that for virtually all large debtor countries ex post spreads from 1970-2000 were close to zero remains true for the 1991 sample.

Table 4. Countries with Secondary-Market Prices in 1991:

Aggregate Ex Post Returns to Private Creditors, 1970-2000 1/

\begin{tabular}{|c|c|c|c|c|c|c|c|c|}
\hline & \multicolumn{4}{|c|}{ Indirect Approach } & \multicolumn{4}{|c|}{ Direct Approach } \\
\hline & Actual & US3y & US10y & UScb & $2 /$ Actual & US3y & US10y & UScb \\
\hline & \multicolumn{8}{|c|}{ All Long Term Debt Flows } \\
\hline All countries & 8.2 & 8.5 & 9.1 & 10.4 & 9.1 & 8.6 & 9.1 & 10.4 \\
\hline Latin America & 8.4 & 8.5 & 9.2 & 10.5 & 9.5 & 8.7 & 9.1 & 10.4 \\
\hline Emerging Asia & 8.3 & 8.0 & 8.9 & 10.0 & 10.0 & 8.4 & 9.4 & 10.4 \\
\hline Other emerging & 7.3 & 8.6 & 8.9 & 10.6 & 6.4 & 8.4 & 8.8 & 10.5 \\
\hline
\end{tabular}

Flows of Public and Publicly Guaranteed Debt Only

$\begin{array}{lllllllll}\text { All countries } & \mathbf{8 . 3} & 8.7 & 9.3 & 10.7 & \mathbf{8 . 8} & 8.6 & 9.2 & 10.6 \\ \text { Latin America } & \mathbf{8 . 3} & 8.7 & 9.4 & 10.7 & \mathbf{9 . 5} & 8.7 & 9.2 & 10.5 \\ \text { Emerging Asia } & \mathbf{9 . 3} & 8.8 & 9.6 & 10.9 & \mathbf{9 . 9} & 8.8 & 9.7 & 10.9 \\ \text { Other emerging } & \mathbf{7 . 6} & 8.7 & 9.0 & 10.6 & \mathbf{5 . 7} & 8.5 & 8.8 & 10.5\end{array}$

Sources: For rates of return data for alternative assets: Board of Governors of the Federal Reserve System, Merrill Lynch; authors' calculations.

1 / Assuming a 2000 debt price of zero for the five countries (Bolivia, Egypt, Republic of Congo, Democratic Republic of Congo and Sudan) which did not have a secondary-market debt price in 2000.

$\underline{2} /$ "US3y","US10y" and "UScb" stand for comparable returns on 3 year and 10 year U.S. treasuries, and U.S. corporate bonds, respectively.

Next, we ask how sensitive the long run results presented in this section are to changes in the prices used to value the debt end-stock for each country. In Table 5, we compute average sovereign debt returns for the 1970-2000 periods using several alternative price assumptions. First, we ask whether the results would be very different if instead of end-2000 prices we had used end-2001 prices, which reflect the effects of Argentina's default. Second, we exclude the prices of collateralized Brady bonds from the average price computation. To the extent that these prices are higher than the prices on otherwise similar but non-collateralized debt instruments, one would expect this to lower the calculated ex post returns. However, it is also sometimes claimed that collateralized Brady bonds are "underpriced"; this would work in the opposite direction. ${ }^{13}$ Finally, we explore the sensitivity of our results to prices that are either

${ }^{13}$ See Buckberg and Kaune, 1996. The "underpricing" of collateralized Brady bonds refers to the fact that "stripped" Brady bond yields-i.e. yields that ignore the collateralized portion of the payments stream-were typically higher than the yields of corresponding noncollateralized international bonds. 
15 or 25 percent higher or lower across the board. 15 percent is roughly the standard deviation of year-to-year average debt price changes in the 1990s, so these are reasonable orders of magnitude.

Table 5. Countries with Secondary-Market Prices in 2000:

Price Sensitivity of Ex-Post Sovereign Returns to Private Creditors 1/

\begin{tabular}{|c|c|c|c|c|c|c|c|}
\hline & \multicolumn{7}{|c|}{ Return on Public and Publicly Guaranteed Debt, 1970-2000 Valuing Debt Endstock at ... } \\
\hline & 2000 prices & 2001 prices & 2000 w/o coll. $2 /$ & $2000+15 \%$ & $2000-15 \%$ & $2000+25 \%$ & $2000-25 \%$ \\
\hline All countries & 8.7 & 8.6 & 8.8 & 9.0 & 8.3 & 9.3 & 8.0 \\
\hline Latin America & 8.7 & 8.5 & 8.8 & 9.1 & 8.4 & 9.3 & 8.1 \\
\hline Argentina & 8.8 & 3.7 & 8.8 & 9.5 & 8.1 & 9.8 & 7.5 \\
\hline Brazil & 8.2 & 8.1 & 8.2 & 8.5 & 7.9 & 8.7 & 7.7 \\
\hline Chile & 10.2 & 10.2 & 10.2 & 10.3 & 10.1 & 10.4 & 10.1 \\
\hline Colombia & 8.1 & 9.0 & 8.1 & 8.8 & 7.2 & 9.2 & 6.6 \\
\hline Ecuador & 4.8 & 5.3 & 4.8 & 5.2 & 4.4 & 5.4 & 4.1 \\
\hline Mexico & 9.7 & 9.7 & 9.8 & 9.9 & 9.3 & 10.1 & 9.1 \\
\hline Panama & 8.4 & 8.4 & 8.5 & 8.9 & 7.9 & 9.1 & 7.6 \\
\hline Peru & 5.3 & 5.6 & 5.4 & 5.6 & 5.1 & 5.7 & 4.9 \\
\hline Venezuela, R.B. & 9.1 & 9.0 & 9.1 & 9.4 & 8.9 & 9.6 & 8.7 \\
\hline Emerging Asia & 9.5 & 9.6 & 9.5 & 9.9 & 9.0 & 10.1 & 8.7 \\
\hline Indonesia & 10.4 & 10.5 & 10.4 & 10.6 & 10.1 & 10.7 & 10.0 \\
\hline Korea, Rep. of & 9.4 & 9.6 & 9.4 & 9.8 & 8.8 & 10.1 & 8.4 \\
\hline Malaysia & 9.9 & 10.0 & 9.9 & 10.4 & 9.5 & 10.6 & 9.1 \\
\hline Philippines & 6.6 & 7.2 & 6.6 & 7.2 & 6.0 & 7.5 & 5.5 \\
\hline Thailand & 10.8 & 10.9 & 10.8 & 11.3 & 10.2 & 11.6 & 9.7 \\
\hline Other emerging & 7.7 & 7.9 & 7.8 & 8.0 & 7.2 & 8.3 & 6.9 \\
\hline Algeria & 8.1 & 8.1 & 8.1 & 8.1 & 8.0 & 8.2 & 7.9 \\
\hline Côte d'Ivoire & 3.1 & 3.2 & $\ldots$ & 3.2 & 3.0 & 3.2 & 2.9 \\
\hline Jordan & 5.1 & 5.3 & 5.3 & 5.3 & 4.8 & 5.5 & 4.6 \\
\hline Lebanon & 6.8 & 5.7 & 6.8 & 10.7 & 0.8 & 12.6 & -4.8 \\
\hline Morocco & 8.0 & 8.0 & 8.0 & 8.2 & 7.8 & 8.3 & 7.7 \\
\hline Nigeria & 5.1 & 5.3 & 5.0 & 5.2 & 5.0 & 5.3 & 4.9 \\
\hline Pakistan & 4.4 & 5.5 & 4.4 & 5.0 & 3.8 & 5.3 & 3.3 \\
\hline Turkey & 9.3 & 9.8 & 9.3 & 10.1 & 8.3 & 10.6 & 7.6 \\
\hline
\end{tabular}

Source: Authors' calculations.

1/ Weighted average of "direct method" and "indirect method", with weights 0.34 and 0.66 .

2/ Excluding prices of collateralized Brady bonds. 
Table 5 indicates that the conclusions of this section are not very sensitive to any of these price assumptions. The use of 2001 rather than 2000 prices makes very little difference in the aggregate results, and makes a significant difference at the individual country level in only one case: Argentina, whose average long run return drops from 8.8 percent to 3.7 percent. This reflects the combination of a collapse in Argentine debt prices (from an average of 88 cents on the dollar at end-2000 to 29 cents at end-2001) and the large volume of Argentine debt outstanding. Excluding prices of collateralized debt makes virtually no difference. ${ }^{14}$ As far as the mechanical increase or decrease of prices by 15 or 25 percent goes, even the latter is not enough to change the basic finding that aggregate returns to emerging markets from 1970 to 2000 are close to those on a medium term U.S. government bond over the same period. Assuming that end-2000 prices had been higher by 25 percent, for example, leads to an ex post spread of around 60 basis points relative to the US 3 year bond, as opposed to less than 10 basis points when actual prices are used.

Finally, there is a question whether we might be understating average long run returns to private creditors because we fail to consider certain types of fees paid to creditor banks. Although the definition of interest payments used in the $G D F$ is quite comprehensive-for example, it includes penalties or past due interest paid in the context of debt restructuring rescheduling deals - it excludes fees paid to the managers of a new bond issue, because they are not payments to the creditors (the bond holders) but rather payments to a third party (the lead manager and co-managers, i.e. banks). However, obtaining high-fee business of this sort is arguably one of the reasons why banks enter in lending relationships with countries. One could thus regard them as indirect compensation for bank lending.

While it is hard to obtain comprehensive data for the entire period, we know that fees of this kind constitute less that one percent of the face value of each bond (typically, they are in the order of $0.25-0.5$ percent). On this basis, we undertook a sensitivity analysis as follows: first, we assumed that all bond disbursements recorded in the GDF generated fees of 1 percent of the disbursement, second, we added these "fees" to interest payments to private creditors in the year in which they arose. The effect of this is to increase the average long run return to private creditors by about 3-5 basis points, depending on the region and debt concept used. Thus, fees associated with bond issues cannot be a significant source of bias. To conclude, the main result of this section - that average long run returns to emerging market debt were about 8-10 percent, implying low or zero ex post spreads-seems to be robust in at least six dimensions: (i) with respect to the method used to construct net transfers

${ }^{14}$ Perhaps surprisingly, the effect is to very slightly increase average 2000 prices and hence returns. This has nothing to do with either collateralization per se or the "underpricing" of Brady bonds, but instead is a mechanical reflection of the fact that Brady "Par" bonds, because of lower coupon payments than both Brady "Discount" bonds and other international bonds, tend to have lower prices. For example, at end-2000 Mexico's Par bonds traded at about 91 cents on the dollar, while its "Discount" bonds traded at 99 cents and the average price of its non-Brady international bonds was about 110 cents. 
between creditors and debtors; (ii) with respect to the debt concept (all privately held debt, or just sovereign debt); (iii) with respect to the definition of the country sample; (iv) across the major debtor countries; (v) with respect to the valuation of the end-stock of debt, and (vi) with respect to the inclusion of fees earned in connection with bond issues.

In principle, there could be two interpretations of this result. First, low ex post returns could simply reflect the fact that realized outcomes were worse than anticipated. This could be due to ex ante pricing errors--ex ante spreads which were too low given the true risks-or simply bad luck - ex ante spreads reflected the true risk, but a relatively bad outcome realized. In an infinitely long sample, neither should matter: instances of good and bad luck will cancel, and pricing errors should go away as investors experience defaults and learn. In a thirty year sample, however, both pricing errors and bad luck might well be noticeable, particularly if maturities were long and the sample included rare events with catastrophic consequences. The 1980s debt crisis is one possible such event, so this might be one explanation for the relatively low ex post spreads. We can investigate it by looking at how returns evolved across time. This is the subject of the next section.

Another possibility is that the low ex post returns we find for emerging market debt are in fact close to the true expected returns. For example, if returns on emerging market debt are uncorrelated, or even negatively correlated, with returns on a relevant world asset portfolio, then our results so far might be consistent with an international version of the capital asset pricing model (see Karolyi and Stulz, 2002). This is explored in the last section of the paper, where we compare the volatility and covariance properties of emerging market debt to those of other asset classes.

\section{Changes in Debt Returns over Time}

We now estimate emerging market returns over shorter horizons. A natural point of departure is to distinguish between the time until the end of the 1980s debt crisis, and the 1990s. To avoid clutter, the table presents ex post spreads rather than returns, namely, the difference between emerging market debt returns and the return on the making the same investment in U.S. 3 year bond rates, computed in the same way as in Table 3. Furthermore, this and the tables that follow focus on public and publicly guaranteed debt. The results would not be substantially affected if we had instead used the broader debt concept that also includes privately issued debt.

Should one think of the long run returns of Tables 2 and 3 in terms of the 1990s not quite offsetting the disaster of the debt crisis? Table 6 shows that the answer depends in part on where exactly the line between the 1980s debt crisis and "the 1990s" is drawn. One possibility is to cut the sample at the time when net debt flows reached their first trough, around 1989. This amounts to comparing the rates of return associated with each of the two boom bust cycles in Figure 2. Alternatively, one could cut the sample at the historical end of the debt crisis, which is usually identified with the Brady deals. These were negotiated between 1989 and the mid-1990s in most debt crisis countries. A good time at which to 
declare the end of the crisis might be 1992, when most large debtors-including Argentina, Brazil and Mexico- had completed their restructurings.

Table 6. The "Eighties" Versus the "Nineties":

Ex Post Spreads, Sovereign Debt, Private Creditors $\underline{1 /}$

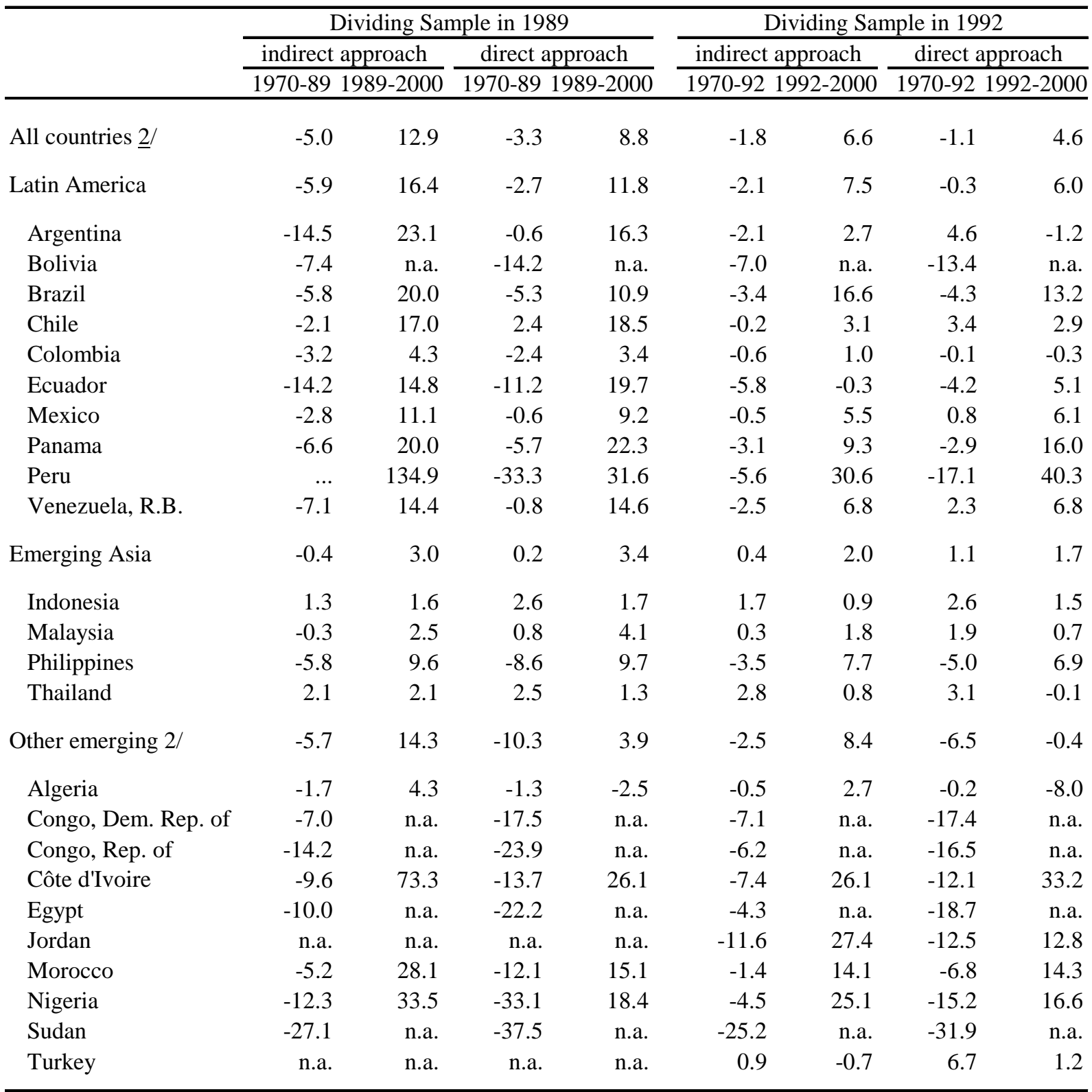

Source: Authors' calculations.

1/ Spreads computed with respect to returns on three-year U.S. government bond.

2/ Only countries with prices in 1989, i.e. excludes Jordan and Turkey. For Bolivia, the two Congos, and Sudan, 2000 debt price is assumed to be zero. 
As it turns out, 1989 marked not just the trough of net debt flows, but also that of secondary market debt prices. By this time, several attempts to resolve the debt crisis had failed, and pessimism prevailed on the chances of finding any orderly resolution of the crisis. ${ }^{15}$ The consequence are highly negative ex post spreads for the 1970-89 period, in the order of -330 to -500 basis points for aggregate flows (and much worse for individual countries), followed by extraordinarily favorable returns for the period 1989-2000. Just three years later, the picture looks much different. Spreads on aggregate flows for 1970-92 period are still negative but much less so, in the order of -110 to -180 basis points. And the remainder of the 1990s no longer looks quite as hot, with average ex post spreads down to about half relative to $1989-2000$.

This leads to two conjectures. The first is that, in spite of highly negative returns until 1989 and the fact that the Brady deal involved write downs in either principal or interest, creditor banks weathered the debt crisis reasonably well (a point already made by Cohen, 1992 and Klingen, 1994). The second is that the 1990s boom could be driven largely by an extraordinary recovery in the early years of the decade, prior to the large official bailouts of the 1990s.

The next two tables basically confirm these points. Table 7 shows ex post spreads on sovereign debt for all Brady deal countries in our sample for the period 1970 until the Brady deal year, both for all private creditors (the perspective adopted in the earlier tables) and only for the banks. For all major creditors, bank spreads were above -300 basis points, according to the generally conservative indirect approach. ${ }^{16}$ In only two cases, Jordan and Nigeria, spreads were clearly lower. In two important cases, Mexico and Venezuela, spreads were basically zero, and in some cases they were even positive. Note also that the banks seem to have done better than the average private creditor. In the end, the strategy of rolling over and waiting for a debt restructuring with official backing seems to have worked well in containing losses and even making profits in some cases. From the banks' perspective, the write downs resulting from the Brady deal were offset by the high prices of the restructured instruments, i.e., an expectation that the new claims would probably be honored.

\footnotetext{
${ }^{15}$ See, for example, the 1990 Journal of Economic Perspectives symposium on that topic (Rogoff, 1990, Bulow and Rogoff, 1990, and other contributions in that volume).

${ }^{16}$ Since Bank loans were mostly restructured into bonds at the time of the Brady deals, we only use the "indirect approach", in which restructurings that generate claims in another debt category are implicitly treated like a repayment in the original category (see Section III).
} 
Table 7. Brady Deal Countries:

Ex Post Sovereign Spreads up to Brady Deal Year $1 /$

\begin{tabular}{|c|c|c|c|}
\hline & \multirow{2}{*}{$\begin{array}{c}\text { Brady deal } \\
\text { year }(\mathrm{B})\end{array}$} & \multirow{2}{*}{$\begin{array}{l}\text { Banks } \underline{2} \text { / } \\
1970-B \\
\end{array}$} & \multirow{2}{*}{$\begin{array}{l}\text { All private } \\
\text { creditors } \\
1970-\mathrm{B} \\
\end{array}$} \\
\hline & & & \\
\hline Argentina & 1992 & -1.9 & -2.1 \\
\hline Brazil & 1992 & -2.7 & -3.4 \\
\hline Ecuador & 1994 & n.a. & -2.9 \\
\hline Mexico & 1990 & 0.3 & -1.7 \\
\hline Panama & 1996 & 1.3 & n.a. \\
\hline Peru & 1996 & -0.9 & -1.2 \\
\hline Venezuela, R.B. & 1990 & 0.2 & -3.4 \\
\hline Philippines & 1992 & -3.3 & -3.7 \\
\hline Algeria & 1999 & 1.0 & -0.4 \\
\hline Côte d'Ivoire & 1997 & -2.7 & -5.2 \\
\hline Jordan & 1993 & -4.3 & -6.8 \\
\hline Nigeria & 1991 & -4.5 & -5.4 \\
\hline \multicolumn{4}{|c|}{$\begin{array}{l}\text { Source: Authors' calculations. } \\
\text { 1/ Refers to public and publicly guaranteed debt, indirect approach only, } \\
\text { spreads with respect to three-year U.S. treasuries. }\end{array}$} \\
\hline
\end{tabular}

Table 8 is analogous to Table 6, except that it splits the 1970 to 2000 period three ways: from 1970 to 1989 , i.e., the "deep debt crisis" period, from end-1989 until end-1994, and from end 1994 until end-2000. The end of 1994 is a natural point at which to split the sample because it marks the beginning of the "era of big bailouts". At this time, the Mexican crisis was already priced into debt, and 3 year returns - as we shall see below-had declined from a peak in 1993. However, the large IMF/U.S. rescue package had not yet been announced. Thus, any positive effect on ex post returns from what could be interpreted as an investorfriendly shift in official policies beginning with the Mexican rescue would not yet be reflected in the 1989-1994 return, and belong entirely in the 1994-2000 period.

The main result is that returns for the 1989-1994 subperiod were far higher than for 19942000, notwithstanding the fact that end-1994 debt prices were already somewhat dampened by the impact of the Mexican crisis. Thus, the exceptionally high returns from 1989 to 2000 primarily seem to reflect a recovery effect from the debt crisis. This said, it is noteworthy that aggregate returns were also quite high in the 1994-2000 period, in spite of the bunching of emerging market crises during those years. Thus, Table 8 does lend some support to the view that in spite of these crises, investors did well on average in the second half of the 1990s. 
Table 8. Decomposing Spreads, 1970-89, 1989-1994, 1994-2000:

Ex Post Sovereign Spreads, Private Creditors $\underline{1 /}$

\begin{tabular}{|c|c|c|c|c|c|c|}
\hline & \multicolumn{3}{|c|}{ indirect approach } & \multicolumn{3}{|c|}{ direct approach } \\
\hline & $1970-89$ & $1989-94$ & $1994-2000$ & $1970-89$ & $1989-94$ & $1994-2000$ \\
\hline All countries $\underline{2} /$ & -5.0 & 16.7 & 6.7 & -3.3 & 11.0 & 5.6 \\
\hline Latin America 2/ & -5.9 & 23.3 & 6.8 & -2.7 & 16.2 & 6.6 \\
\hline Argentina & -14.5 & 28.5 & 4.9 & -0.6 & 28.6 & 6.1 \\
\hline Bolivia & -7.4 & n.a. & n.a. & -14.2 & n.a. & n.a. \\
\hline Brazil & -5.8 & 28.6 & 8.6 & -5.3 & 16.1 & 5.7 \\
\hline Chile & -2.1 & 22.8 & 1.0 & 2.4 & 25.2 & 0.9 \\
\hline Colombia & -3.2 & 12.1 & -1.8 & -2.4 & 12.1 & -3.2 \\
\hline Ecuador & -14.2 & 40.5 & -9.3 & -11.2 & 40.3 & -5.7 \\
\hline Mexico & -2.8 & 12.9 & 8.6 & -0.6 & 9.0 & 8.9 \\
\hline Panama & -6.6 & 45.9 & 0.7 & -5.7 & 39.2 & 6.4 \\
\hline Peru & n.a. & 144.3 & -4.8 & -33.3 & 50.8 & 3.5 \\
\hline Venezuela, R.B. & -7.1 & 14.3 & 13.9 & -0.8 & 14.7 & 13.8 \\
\hline Emerging Asia $\underline{2} /$ & -0.4 & 5.4 & 0.0 & 0.2 & 6.3 & -0.2 \\
\hline Indonesia & 1.3 & 3.5 & -1.3 & 2.6 & 3.0 & -0.3 \\
\hline Korea & n.a. & n.a. & 2.2 & n.a. & n.a. & 1.6 \\
\hline Malaysia & -0.3 & 4.7 & 0.2 & 0.8 & 8.6 & -0.4 \\
\hline Philippines & -5.8 & 14.1 & 2.0 & -8.6 & 14.8 & 1.4 \\
\hline Thailand & 2.1 & 3.9 & 0.2 & 2.5 & 3.6 & -1.0 \\
\hline Other emerging $2 /$ & -5.7 & 10.5 & 28.3 & -10.3 & -0.5 & 13.1 \\
\hline Algeria & -1.7 & -6.7 & 51.6 & -1.3 & -12.2 & 15.2 \\
\hline Congo, Dem. Rep. of & -7.0 & -5.0 & n.a. & -17.5 & -6.3 & n.a. \\
\hline Congo, Rep. of & -14.2 & n.a. & n.a. & -23.9 & n.a. & n.a. \\
\hline Côte d'Ivoire & -9.6 & 86.2 & 1.3 & -13.7 & 34.0 & 2.1 \\
\hline Egypt & -10.0 & 33.6 & n.a. & -22.2 & -6.6 & n.a. \\
\hline Jordan & n.a. & n.a. & 24.9 & n.a. & n.a. & 12.6 \\
\hline Lebanon & n.a. & n.a. & 2.0 & n.a. & n.a. & 1.8 \\
\hline Morocco & -5.2 & 32.3 & 7.1 & -12.1 & 19.5 & 7.4 \\
\hline Nigeria & -12.3 & 27.5 & 33.6 & -33.1 & 16.6 & 23.3 \\
\hline Sudan & -27.1 & 25.7 & n.a. & -37.5 & 25.6 & n.a. \\
\hline Turkey & n.a. & n.a. & 0.1 & n.a. & n.a. & 1.0 \\
\hline
\end{tabular}

Source: Authors' calculations.

1 / Spreads computed with respect to three-year U.S. government bond

2/ Only countries with prices in 1989, i.e. excludes Jordan, Korea, Lebanon and Turkey. For

Bolivia and the Republic of Congo, 1994 and 2000 prices are not available and are assumed to be zero when computing aggregate returns that include these countries. The same applies to the Democratic Republic of Congo with respect to 2000 only. 
Table 8 also shows some interesting regional and cross-country differences. One of the starkest is the contrast between the bust-boom cycles in Latin America and East Asia. It is Latin America that drives the aggregate picture: a big bust until 1989, a vehement recovery in the early 1990s, and generally a continued good performance until the end of 2000. Asia, in contrast, did not experience much of a bust in the eighties, and would exhibit aggregate positive spreads for the 1970-89 period, were it not for the Philippines, which until the mid1990s resembles the Latin American countries in terms of its return pattern. Asia and Latin America also differ with respect to the second half of the 1990s, when aggregate Asian returns were poor. Of the four countries hit hardest by the crisis, only Korea achieved a modest positive spread over the whole period. Thus, if official policies helped returns in Latin America stay high in the second half of the 1990s in spite of a succession of crises, they do not seem to have achieved all that much for spreads on debt flows to Asia during the same period, at least comparatively.

We next go one step further and decompose the 1986-2000 period for which secondary market debt prices are available into a sequence of overlapping three-year periods (Table 9). To be able to show a reasonably long series, we only include countries with continuous secondary market debt prices since at least 1990, except for two-Korea and Chile- —which are shown as memorandum items, but not included in the aggregate concepts. As before, we show a weighted average of the "indirect" and "direct" methodologies, using a weight of two thirds for the indirect approach. The results discussed below are not sensitive to this choice.

Consider first the lines for "All countries" and "All Brady countries" at the top of the Table 9, which confirm the basic message of the earlier tables. First, spreads over 3 year periods peaked during the early 1990s. This is the rebound from the debt crisis, at a time when the Brady deals were successfully being concluded and a new wave of capital flows to emerging markets began to take off, well ahead of the second Mexican crisis. Second, following the Mexican crisis, there is a second period of peak spreads from 1994-97, yielding ex post spreads of more than 1300 basis points in the Brady deal countries, corresponding to returns of about 20 percent. If there is anything in this paper to support the view that official interventions in the 1990s helped emerging market investors earn high returns even in times of crises, it would be this observation. Ex post spreads decline to significantly lower levels only in 1998, after the Russian crisis. 
Table 9. Spreads over Three-Year Periods:

Ex Post Spreads, Public and Publicly Guaranteed Debt, Private Creditors $\underline{1 /}$

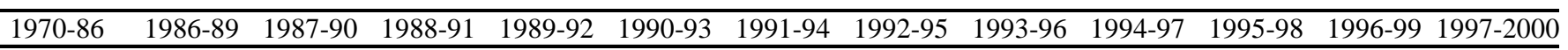

\begin{tabular}{|c|c|c|c|c|c|c|c|c|c|c|c|c|c|}
\hline All countries $\underline{2 /}$ & n.a. & n.a. & n.a. & n.a. & n.a. & 18.7 & 5.8 & 8.0 & 1.2 & 9.3 & 1.5 & 0.6 & 0.7 \\
\hline All Brady countries $\underline{2} /$ & -3.0 & -13.7 & 9.6 & 23.7 & 29.1 & 23.2 & 7.8 & 9.5 & 0.7 & 13.8 & 4.7 & 1.1 & 0.9 \\
\hline All non-Brady countries $\underline{2} /$ & n.a. & n.a. & n.a. & n.a. & n.a. & 9.3 & 2.3 & 5.3 & 2.3 & 0.1 & -5.0 & -0.8 & 0.0 \\
\hline Latin America countries 2/ & -2.4 & -13.3 & 9.8 & 21.7 & 29.0 & 22.0 & 7.0 & 8.9 & 0.1 & 12.9 & 3.7 & 0.8 & 0.8 \\
\hline Argentina & -2.7 & -22.0 & 16.8 & 52.3 & 55.6 & 30.0 & 1.5 & -2.7 & 0.5 & 13.8 & 6.1 & 1.8 & -0.6 \\
\hline Brazil & -1.9 & -19.9 & 12.7 & 0.3 & 20.0 & 16.4 & 23.1 & 26.6 & -2.6 & 12.6 & 1.5 & 1.5 & 1.6 \\
\hline Colombia & -2.0 & -4.5 & 5.6 & 16.5 & 13.1 & 14.3 & 7.8 & 12.6 & 6.9 & -0.3 & -8.4 & -3.3 & -3.8 \\
\hline Ecuador & -2.3 & -37.4 & -12.8 & 33.1 & 44.4 & 53.5 & 36.3 & 3.2 & -8.0 & -0.3 & 4.3 & -14.8 & -15.6 \\
\hline Mexico & -2.5 & 0.4 & 8.1 & 21.9 & 20.5 & 20.3 & -0.5 & 1.4 & -0.6 & 12.6 & 6.7 & 4.1 & 4.6 \\
\hline Peru & -20.2 & -39.9 & -30.2 & 48.1 & 105.6 & 501.8 & 138.2 & 82.5 & 6.3 & -3.3 & -13.9 & -18.4 & 0.0 \\
\hline Venezuela, R.B. & -1.1 & -14.2 & 6.0 & 29.4 & 27.4 & 12.1 & -11.1 & 3.5 & 7.5 & 28.9 & 8.1 & -2.5 & -3.7 \\
\hline Memorandum item: Chile & -3.1 & 10.1 & 20.5 & 36.5 & 32.0 & 14.6 & 4.5 & n.a. & n.a. & n.a. & n.a. & n.a. & n.a. \\
\hline Asian countries $\underline{2} /$ & n.a. & n.a. & n.a. & n.a. & 6.5 & 9.2 & 5.0 & 4.7 & 1.7 & -3.9 & -4.8 & -0.3 & 3.4 \\
\hline Indonesia & n.a. & n.a. & n.a. & 4.6 & 3.9 & 1.9 & 1.9 & 4.4 & 3.9 & -3.9 & -14.5 & -4.9 & 2.3 \\
\hline Malaysia & n.a. & n.a. & n.a. & 3.3 & 7.8 & 7.9 & 5.8 & 1.0 & -1.1 & -5.0 & -0.4 & 3.0 & 4.5 \\
\hline Philippines & -7.9 & -3.3 & 6.5 & 36.0 & 12.5 & 44.2 & 20.1 & 18.9 & 5.3 & 5.3 & 3.9 & 2.4 & -0.8 \\
\hline Thailand & n.a. & n.a. & n.a. & n.a. & 6.7 & 6.6 & 0.5 & 0.8 & -2.1 & -10.3 & -2.8 & 0.4 & 8.0 \\
\hline Memorandum item: Korea, Rep. of & n.a. & n.a. & n.a. & n.a. & n.a. & n.a. & n.a. & n.a. & -1.7 & -12.5 & -9.7 & 1.4 & 9.5 \\
\hline Other countries $\underline{2} /$ & n.a. & n.a. & n.a. & n.a. & n.a. & 16.2 & 2.9 & 8.2 & 5.1 & 8.2 & -1.1 & 0.2 & -2.8 \\
\hline Côte d'Ivoire & -4.4 & -46.5 & -39.5 & -12.7 & 60.2 & 128.6 & 54.3 & 46.6 & 24.3 & 9.2 & 13.8 & -5.6 & -9.2 \\
\hline Morocco & -5.0 & -14.4 & -6.5 & 7.3 & 29.3 & 46.5 & 37.1 & 20.3 & 5.9 & 11.7 & 9.3 & 1.7 & 1.2 \\
\hline Nigeria & -17.2 & -19.3 & 14.7 & 52.2 & 31.1 & 22.6 & 11.8 & 19.6 & 22.1 & 40.0 & 20.1 & 3.6 & 1.0 \\
\hline Turkey & n.a. & n.a. & n.a. & n.a. & n.a. & 9.5 & -3.0 & 5.0 & 2.2 & 4.4 & -4.4 & -0.3 & -3.7 \\
\hline
\end{tabular}

Source: Authors' calculations.

$\underline{1}$ / Average of returns according to "direct" and "indirect" approaches. Spreads computed with respect to three-year U.S. government bond.

2/ Refers only to countries shown in the table, excluding memorandum countries. 
Note, however, that high average returns during 1994-97 were driven mainly by countries that were not directly affected by the Asian crisis and the associated official loans. Moreover, it could be argued that the high emerging market debt returns during this period were part of a broader financial market boom. For example, returns on U.S. high-yield bonds were also exceptionally high during the 1994-1997 period (almost 15 percent, after averaging about 10 percent or less during the preceding years). ${ }^{17}$ Finally, it is worth noting that while the collapse of net flows after 1997 is associated with much lower returns compared to the 1990s average, spreads were still slightly positive. In contrast, the collapse of net flows after the debt crisis was accompanied by large negative spreads.

The cross-sectional comparison is also instructive. Consider first the contrast between the Brady countries and the non-Brady countries. As one would expect, spreads in the non-Brady countries are much lower in the 1990-93 period, reflecting the absence of a recovery effect. The 1994-97 peak in the Brady country spreads is also absent in the non-Brady group. This is clearly an Asia crisis effect. However, as in the Brady group, returns from 1995-1998 are even worse, coinciding with the second year of the Asian crisis and the Russian crisis. Finally, note the fast recovery of spreads in 1997-2000 in Korea, Thailand, and to a lesser extent Malaysia.

Finally, consider Table 10, which provides a summary of how long run returns have evolved over time. Like Table 9, Table 10 shows rolling spreads, but keeps the initial year, 1970, fixed. The punch line is that, following very poor returns in the Brady countries from 1970 to the late eighties, the recoveries of the 1990s have fallen just short of pushing spreads back into positive territory for the entire period, although they came close in several instances (notably, at end1993, end 1997, and again in 1999 and 2000). In contrast, the non-Brady countries never experienced negative ex post spreads in the aggregate.

\footnotetext{
${ }^{17}$ Zhang (1999) argues that the 1995-1997 boom in debt prices was driven by liquidity rather than "moral hazard" related to official policies. Dell' Ariccia, Schnabel and Zettelmeyer (2002) show that a structural break in the determinants of emerging market debt prices occurred in 1998, and argue that this is consistent with the view that prices prior to the Russian crisis were artificially high due to the anticipation of official intervention.
} 
Table 10. Average Long-Run Spreads over an Increasing Horizon:

Ex Post Spreads, Public and Publicly Guaranteed Debt, Private Creditors $\underline{1 /}$

\section{$\begin{array}{lllllllllllllllll}1970-86 & 1970-87 & 1970-88 & 1970-89 & 1970-90 & 1970-91 & 1970-92 & 1970-93 & 1970-94 & 1970-95 & 1970-96 & 1970-97 & 1970-98 & 1970-99 & 1970-2000\end{array}$}

\begin{tabular}{|c|c|c|c|c|c|c|c|c|c|c|c|c|c|c|c|}
\hline All countries $\underline{2} /$ & n.a. & n.a. & n.a. & n.a. & -2.4 & -1.7 & -1.3 & 0.0 & -0.9 & -0.5 & 0.0 & -0.1 & -0.3 & 0.0 & 0.0 \\
\hline All Brady countries $\underline{2} /$ & -3.0 & -5.7 & -6.4 & -5.7 & -3.1 & -2.5 & -2.1 & -0.4 & -1.6 & -1.1 & -0.5 & -0.4 & -0.7 & -0.4 & -0.3 \\
\hline All non-Brady countries $2 /$ & n.a. & n.a. & n.a. & n.a. & 0.3 & 1.0 & 1.2 & 1.5 & 1.3 & 1.6 & 1.5 & 1.1 & 0.9 & 1.3 & 1.1 \\
\hline Latin America countries 2/ & -2.4 & -4.8 & -5.4 & -5.0 & -2.5 & -2.0 & -1.6 & 0.0 & -1.1 & -0.7 & -0.1 & 0.0 & -0.4 & -0.1 & 0.0 \\
\hline Argentina & -2.7 & -11.5 & -13.6 & -9.7 & -4.2 & -1.4 & 0.2 & 0.4 & -0.8 & -0.1 & 0.4 & 0.6 & 0.6 & 0.6 & 0.6 \\
\hline Brazil & -1.9 & -4.7 & -4.4 & -5.6 & -2.3 & -3.9 & -3.7 & -0.4 & -1.8 & -1.5 & -0.8 & -0.8 & -1.4 & -0.7 & -0.7 \\
\hline Colombia & -2.0 & -4.0 & -4.4 & -2.9 & -2.1 & -0.7 & -0.4 & 0.1 & 0.5 & 1.0 & 0.8 & 0.4 & -0.1 & 0.4 & -0.1 \\
\hline Ecuador & -2.3 & -8.2 & -14.8 & -13.2 & -9.5 & -7.6 & -5.2 & -1.3 & -2.3 & -4.4 & -2.5 & -2.2 & -3.4 & -4.1 & -3.7 \\
\hline Mexico & -2.5 & -2.6 & -2.9 & -2.1 & -1.2 & -0.3 & -0.1 & 0.7 & -0.2 & 0.1 & 0.5 & 0.7 & 0.5 & 0.8 & 0.9 \\
\hline Peru & -20.2 & -33.1 & -36.7 & -33.3 & -34.9 & -13.3 & -9.5 & -2.8 & -3.6 & -2.5 & -2.0 & -3.6 & -3.6 & -3.3 & -3.4 \\
\hline Venezuela, R.B. & -1.1 & -3.5 & -5.9 & -5.0 & -1.6 & -0.3 & -0.8 & 0.2 & -1.4 & -0.4 & 0.8 & 0.9 & 0.2 & 0.6 & 0.6 \\
\hline Memorandum item: Chile & -3.1 & -2.5 & -1.9 & -0.6 & 0.5 & 1.1 & 1.0 & 1.1 & 1.2 & n.a. & n.a. & n.a. & n.a. & 1.1 & 1.1 \\
\hline Asian countries $\underline{2} /$ & n.a. & n.a. & n.a. & -0.2 & -0.1 & 0.4 & 0.6 & 0.9 & 0.8 & 0.9 & 0.8 & 0.5 & 0.5 & 0.8 & 0.7 \\
\hline Indonesia & n.a. & n.a. & 1.8 & 1.8 & 2.0 & 2.0 & 2.0 & 1.9 & 2.0 & 2.1 & 1.9 & 1.6 & 1.2 & 1.6 & 1.6 \\
\hline Malaysia & n.a. & n.a. & 0.3 & 0.1 & 0.3 & 0.5 & 0.9 & 1.0 & 1.0 & 0.8 & 0.7 & 0.5 & 0.7 & 0.9 & 0.8 \\
\hline Philippines & -7.9 & -12.4 & -13.2 & -6.8 & -7.5 & -5.0 & -4.0 & -2.3 & -2.6 & -2.3 & -1.8 & -2.0 & -1.8 & -1.4 & -1.9 \\
\hline Thailand & n.a. & n.a. & n.a. & 2.3 & 2.3 & 3.0 & 2.9 & 2.8 & 2.6 & 2.4 & 2.1 & 1.1 & 2.0 & 1.9 & 1.9 \\
\hline Memorandum item: & & & & & & & & & & & & & & & \\
\hline Korea, Rep. of & n.a. & n.a. & n.a. & n.a. & n.a. & n.a. & n.a. & 0.9 & 0.4 & 0.8 & 0.6 & -0.5 & 0.0 & 0.7 & 0.7 \\
\hline Other countries $\underline{2} /$ & n.a. & n.a. & n.a. & n.a. & -5.1 & -3.0 & -2.5 & -1.4 & -2.0 & -1.0 & -0.7 & -0.8 & -1.1 & -0.7 & -1.0 \\
\hline Côte d'Ivoire & -4.4 & -7.0 & -8.9 & -11.0 & -10.6 & -9.3 & -9.0 & -7.8 & -6.9 & -7.1 & -6.4 & -6.0 & -6.3 & -6.3 & -6.2 \\
\hline Morocco & -5.0 & -6.1 & -7.0 & -7.5 & -6.7 & -5.1 & -3.2 & -1.5 & -1.8 & -1.6 & -1.0 & -1.0 & -1.0 & -0.9 & -0.9 \\
\hline Nigeria & -17.2 & -22.8 & -30.5 & -19.3 & -12.0 & -9.4 & -8.1 & -6.5 & -6.7 & -5.5 & -4.1 & -4.0 & -4.2 & -3.7 & -3.9 \\
\hline Turkey & n.a. & n.a. & n.a. & n.a. & 1.1 & 3.2 & 2.9 & 3.3 & 2.0 & 3.3 & 2.9 & 2.5 & 2.0 & 2.5 & 1.8 \\
\hline
\end{tabular}

Source: Authors' calculations.

1/ Average of returns according to "direct" and "indirect" approaches. Spreads computed with respect to three-year U.S. government bond, in points.

2/ Refers only to countries shown in the table, excluding memorandum countries. 
On the whole, this section - and particularly Table 10 — seems to back the notion that history matters in explaining the relatively low average returns for the entire 1970-2000 period. First, consider the time dimension: there is a sense from Table 10 that if given enough time, long run spreads in the Brady group will eventually return into positive territory. The debt crisis of the 1980s still does not seem to have "washed out" in terms of its impact on long run returns. Second, consider the cross-sectional dimension. If our "long run" results were indicative of the true long run (i.e. an infinitely long sample), it would be very surprising to have lower spreads in the Brady group than in the non-Brady group. By definition, long run spreads should reflect true risk premia. Risk premia should be higher in the group of countries whose debt returns have undergone the more violent crashes and more vehement recoveries - the Brady group. The opposite is true in Table 10.

This said, it remains a bit of a puzzle that even the ex post spreads of the non-Brady countries, while positive, are quite low (in the long run, just over 100 basis points). By definition, these are the countries that did not write down their debts after the 1980s debt crisis. But perhaps their long run spreads just seem low because we have an exaggerated expectation of what equilibrium returns should be in emerging markets, given their histories of explosive booms and wrenching crises? Put differently, it would be nice to get a sense of how far the realized returns we have computed for 1970-2000 are from the equilibrium returns that one would expect, given the volatilities and covariances of returns that are actually observed for various emerging market countries and country groups. This is the question to which we turn next.

\section{Volatility and Comovement with Returns on Other Asset Classes}

Flows and stocks in the World Bank debt database are available at an annual frequency, so the shortest horizon for which emerging market debt returns can be computed in this paper is one year. Since we are constrained by the lack of secondary market debt prices prior to 1986, this gives us a maximum of 14 data points to compute a standard deviation of returns and covariances with returns on other asset classes. This is not much, but enough for a few rudimentary comparisons, which we present in two tables. Table 11 looks at aggregate debt returns and how they relate to U.S., world, and emerging market equity returns, as well as corporate and high-yield bond returns in the U.S. Our comparisons are based on Merrill Lynch bond return indices for U.S. corporate and high-yield bonds, and various Morgan Stanley Capital Indices for equities. In Appendix IV, we repeat this exercise for the largest individual emerging market economies, comparing them with both the aggregate bond and equity return indices and with country-specific equity indices (Appendix Table 7). The results are quite similar. As before, we focus on public and publicly guaranteed debt and look at a weighted average of the "indirect" and "direct" methods.

Table 11 contains three sets of information. First, it compares emerging market debt returns with the returns on the alternative assets not only for 1970-2000 but for 1990-2000 as well as for the longest period for which data for the alternative asset return is available. This period is denoted " $\tau_{p}-2000$ "; $\tau_{p}$ is typically 1986 or 1987 . Second, for this longest period, standard deviations of annual returns are computed for both emerging market debt and alternative 
asset returns. Third, the covariance properties of both emerging market debt and the alternative assets are explored by regressing their returns on returns to world, U.S. and emerging stock markets, as well as U.S. corporate and high-yield bonds. Coefficients and standard errors from these regressions are reported in Table 11. The returns "data" on which these regressions and standard deviations are based is in Appendix IV (Appendix Table 8).

Table 11. Returns, Volatility, and Betas: Results for Aggregate Flows (Standard Errors in Parentheses)

\begin{tabular}{|c|c|c|c|c|c|c|c|c|c|c|}
\hline & \multicolumn{3}{|c|}{ Returns $\underline{1 /}$} & \multirow[b]{2}{*}{$\tau_{\mathrm{p}}$} & \multicolumn{6}{|c|}{ Volatility and "Betas" $\underline{2 /}$} \\
\hline & $1970-200$ & $990-2000$ & $\tau_{\mathrm{p}}-2000$ & & St. dev. & $\beta_{\mathrm{Wd}}$ & $\beta_{\mathrm{US}}$ & $\beta_{\mathrm{EM}}$ & $\beta_{\mathrm{UScp}}$ & $\beta_{\text {UShy }}$ \\
\hline \multicolumn{11}{|c|}{ I. Emerging Market Debt Flows, Public and Publicly Guaranteed Debt, Private Creditors $\underline{3}$ / } \\
\hline All countries & 8.6 & 12.7 & 12.7 & 1990 & 15.9 & $\begin{array}{c}0.47 \\
(0.41)\end{array}$ & $\begin{array}{c}0.14 \\
(0.36)\end{array}$ & $\begin{array}{c}0.31 \\
(0.11)\end{array}$ & $\begin{array}{c}0.92 \\
(0.68)\end{array}$ & $\begin{array}{c}0.66 \\
(0.40)\end{array}$ \\
\hline All Brady countries & 8.4 & 14.6 & 10.2 & 1986 & 25.4 & $\begin{array}{l}-0.32 \\
(0.51)\end{array}$ & $\begin{array}{l}-0.06 \\
(0.48)\end{array}$ & $\begin{array}{c}0.18 \\
(0.19)\end{array}$ & $\begin{array}{l}0.90 \\
(1.05)\end{array}$ & $\begin{array}{l}0.19 \\
(0.62)\end{array}$ \\
\hline All non-Brady countries & 9.5 & 8.8 & 8.8 & 1990 & 8.4 & $\begin{array}{c}0.31 \\
(0.21)\end{array}$ & $\begin{array}{c}0.14 \\
(0.18)\end{array}$ & $\begin{array}{c}0.19 \\
(0.05)\end{array}$ & $\begin{array}{c}0.42 \\
(0.37)\end{array}$ & $\begin{array}{c}0.45 \\
(0.18)\end{array}$ \\
\hline Latin American countries & 8.7 & 13.7 & 10.2 & 1986 & 25.3 & $\begin{array}{l}-0.37 \\
(0.51)\end{array}$ & $\begin{array}{l}-0.13 \\
(0.48)\end{array}$ & $\begin{array}{c}0.15 \\
(0.20)\end{array}$ & $\begin{array}{c}0.83 \\
(1.07)\end{array}$ & $\begin{array}{c}0.14 \\
(0.62)\end{array}$ \\
\hline Asian countries & 9.5 & 9.3 & 9.6 & 1989 & 7.5 & $\begin{array}{c}0.10 \\
(0.17)\end{array}$ & $\begin{array}{l}-0.06 \\
(0.15)\end{array}$ & $\begin{array}{c}0.17 \\
(0.04)\end{array}$ & $\begin{array}{l}-0.01 \\
(0.35)\end{array}$ & $\begin{array}{l}0.17 \\
(0.19)\end{array}$ \\
\hline \multicolumn{11}{|c|}{ II. Comparison Series $\underline{4}$} \\
\hline $\begin{array}{l}\text { MSCI AC World } \\
\text { weighted }\end{array}$ & $\begin{array}{l}\cdots \\
\ldots\end{array}$ & $\begin{array}{l}12.0 \\
12.9\end{array}$ & $\begin{array}{l}10.8 \\
11.9\end{array}$ & 1987 & 14.1 & $\begin{array}{l}\cdots \\
\ldots\end{array}$ & $\begin{array}{l}\cdots \\
\cdots\end{array}$ & $\begin{array}{l}\cdots \\
\cdots\end{array}$ & $\begin{array}{l}\cdots \\
\cdots\end{array}$ & $\begin{array}{l}\cdots \\
\cdots\end{array}$ \\
\hline $\begin{array}{l}\text { MSCI U.S. } \\
\text { weighted }\end{array}$ & $\begin{array}{l}12.7 \\
14.7\end{array}$ & $\begin{array}{l}17.7 \\
19.3\end{array}$ & $\begin{array}{l}15.9 \\
15.6\end{array}$ & 1986 & 15.1 & $\begin{array}{c}0.81 \\
(0.21)\end{array}$ & $\begin{array}{l}\cdots \\
\cdots\end{array}$ & $\begin{array}{l}\cdots \\
\cdots\end{array}$ & $\cdots$ & $\cdots$ \\
\hline $\begin{array}{l}\text { MSCI Emerging Markets } \\
\text { weighted }\end{array}$ & $\begin{array}{l}\cdots \\
\ldots\end{array}$ & $\begin{array}{c}8.3 \\
21.4\end{array}$ & $\begin{array}{l}12.4 \\
33.7\end{array}$ & 1987 & 36.5 & $\begin{array}{c}1.53 \\
(0.63)\end{array}$ & $\begin{array}{c}0.62 \\
(0.70)\end{array}$ & $\begin{array}{l}\cdots \\
\cdots\end{array}$ & $\begin{array}{c}0.69 \\
(1.63)\end{array}$ & $\begin{array}{l}1.26 \\
(0.85)\end{array}$ \\
\hline $\begin{array}{l}\text { 10-Year Treasury Bond } \\
\text { weighted }\end{array}$ & 9.3 & $\begin{array}{l}7.7 \\
8.4\end{array}$ & $\begin{array}{l}7.3 \\
7.6\end{array}$ & 1986 & 9.3 & $\begin{array}{c}0.03 \\
(0.19)\end{array}$ & $\begin{array}{c}0.24 \\
(0.16)\end{array}$ & $\begin{array}{c}-0.02 \\
0.08\end{array}$ & $\begin{array}{l}1.30 \\
(0.12)\end{array}$ & $\begin{array}{l}0.31 \\
(0.21)\end{array}$ \\
\hline $\begin{array}{l}\text { ML U.S. Treasury Master } \\
\text { weighted }\end{array}$ & $\begin{array}{l}\cdots \\
\cdots\end{array}$ & $\begin{array}{l}7.9 \\
8.3\end{array}$ & $\begin{array}{l}7.9 \\
8.1\end{array}$ & 1986 & 6.3 & $\begin{array}{c}0.00 \\
(0.13)\end{array}$ & $\begin{array}{c}0.14 \\
(0.11)\end{array}$ & $\begin{array}{l}0.00 \\
0.05\end{array}$ & $\begin{array}{c}0.89 \\
(0.08)\end{array}$ & $\begin{array}{l}0.21 \\
(0.15)\end{array}$ \\
\hline $\begin{array}{l}\text { ML U.S. Corporate Master } 4 / \\
\text { weighted }\end{array}$ & $\begin{array}{c}9.7 \\
10.7\end{array}$ & $\begin{array}{l}8.5 \\
9.1\end{array}$ & $\begin{array}{l}8.4 \\
8.8\end{array}$ & 1986 & 6.7 & $\begin{array}{c}0.08 \\
(0.14)\end{array}$ & $\begin{array}{c}0.21 \\
(0.11)\end{array}$ & $\begin{array}{l}0.02 \\
0.06\end{array}$ & $\begin{array}{l}\cdots \\
\cdots\end{array}$ & $\begin{array}{l}0.35 \\
(0.14)\end{array}$ \\
\hline $\begin{array}{l}\text { ML U.S. High Yield Master } \\
\text { weighted }\end{array}$ & $\begin{array}{l}\cdots \\
\cdots\end{array}$ & $\begin{array}{l}11.1 \\
14.1\end{array}$ & $\begin{array}{l}9.0 \\
9.4\end{array}$ & 1986 & 11.4 & $\begin{array}{c}0.38 \\
(0.22)\end{array}$ & $\begin{array}{c}0.40 \\
(0.18)\end{array}$ & $\begin{array}{l}0.13 \\
0.09\end{array}$ & $\begin{array}{c}1.07 \\
(0.42)\end{array}$ & $\begin{array}{l}\cdots \\
\cdots\end{array}$ \\
\hline
\end{tabular}

Source: Authors' calculations.

$\underline{1 /}$ Average of returns according to "direct" and "indirect" approaches. Gross U.S. dollar returns throughout.

$\underline{2}$ / Based on annual returns sample, $\tau_{\mathrm{p}}-2000$. Betas refer to the world equity markets, U.S. equity markets, emerging equity markets, U.S. corporate bonds, and U.S. high yield bonds, respectively.

$\underline{3}$ / Country groups refers only to countries shown in Tables 8 and 9, excluding memorandum countries.

4/ "Weighted" returns are computed using index and actual emerging market sovereign debt flows. For 1970-2000 and 1990-2000 use flows to "All countries" category above. For 1986 or 1987 to 2000 use flows to Brady country group. 5/ Index starts in 1972. Return shown for 1970-2000 is in fact average annual return for the period 1972-2000. 
The main results from the table are as follows. First, while aggregate emerging market debt returns were low for the 1970-2000 period, they look comparatively good for the 1990shigher than U.S. corporate bond returns and about in line with returns on world stock markets and U.S. high-yield bonds, although not quite as high as U.S. stock returns. Note that these comparisons are somewhat sensitive to whether one takes unweighted averages of the alternative returns, or weights them by the actual flows of emerging market debt, as we did in previous sections (italics). Because the large expansion of debt flows in the early 1990s preceded or coincided with rallies in other asset markets, and the reversal of debt flows in 1998-99 preceded the stock market decline of 2000, the weighted returns are usually higher than the unweighted returns. The difference is not very large except in one case: emerging market equity returns, which were highly volatile, and turn out much higher if weighted by the pattern of debt flows. For individual country equity returns, which are even more volatile, the effect of weighting by debt flows can be even more dramatic (Appendix IV).

Second, the volatility of emerging market debt returns in the 1986-2000 period was about as high as that of U.S. or world stock markets - with a standard deviation of around 15-and slightly higher than that of U.S. high-yield bond returns. But it was significantly lowerabout half-than that of emerging market equity returns.

Third, the estimated "beta" of emerging market debt with respect to both U.S. and world stock market was insignificantly different from zero, and even slightly negative, depending on the regression period and country aggregate. This is in part driven by lack of power: the hypothesis that the true beta is equal to 1 could not be rejected either. However, even in this small sample, both U.S. corporate bond returns and U.S. high-yield bonds have significant positive betas with respect to the U.S. stock market. So do emerging market equities with respect to the world stock market. Thus, the data is certainly consistent with the view that emerging market debt flows are less correlated with the U.S. and world stock markets than these other asset classes.

Fourth, while emerging market debt returns are not significantly correlated with U.S. and world stock returns, they are significantly positively correlated with emerging market equity returns. The estimated beta with respect to emerging market equities is in the $0.15-0.3$ range. Emerging market debt returns also seem correlated with U.S. corporate and high-yield bond returns, but the estimated betas are not significantly different from zero in the short sample of annual returns which we have to work with here.

Finally, note again the different characteristics of Latin American and Asian (or alternatively Brady country and non-Brady country) debt returns. As we had already seen, the latter were much lower for the 1990s: about 9 percent, as opposed to about 14 percent. This was slightly higher than the return on U.S. corporates in the same period. However, the volatility of Asian/non-Brady country debt returns is also much lower than that of the Brady country group, and close to that of U.S. corporates. And Asian debt returns appear uncorrelated not just with the U.S. and world stock markets but also with U.S. corporate and high-yield bond returns. On this basis, the low spreads on Asian debt are arguably consistent with the CAPM. 


\section{Conclusions}

This paper has estimated returns to emerging-market debt flows in the "long run" (19702000) and over shorter periods. Investors earned about the same, over the whole period, as they would have by earned by investing in medium-term U.S. government bonds. Thus, average, ex post risk premiums for the 1970-2000 period have been close to zero. This result is robust in several dimensions, including with respect to the debt concept, the definition of the country sample, the method used to construct net transfers, and the valuation of the endstock of debt. It also requires explanation. While one would expect long-run ex post spreads, which reflect realized defaults and debt restructurings, to be much lower than ex ante spreads, they should be significantly positive. Risk-averse investors will ask to be compensated for the anxiety of holding a risky claim.

One interpretation is that in spite of 30 years of data, our "long-run" result is still not really about the long run, but merely summarizes two boom-bust cycles with particularly outcomes. The first cycle - from the mid-1970s until flows and debt prices reached a trough in 1989turned out much worse than had been expected 10 or 15 years earlier, as reflected in very poor ex post returns. This could have been the result of mispricing in the 1970s-as investors underestimated the risk of lending to emerging-market countries because the memory of previous sovereign defaults had waned-or just an instance of very bad luck. By the late 1980s, investor expectations were very low and ex ante risk premiums high. In most countries outcomes exceeded expectations during the 1990s, leading to sizable ex post premiums, but this was not quite enough to bring long-run premiums in most debt-crisis countries back into the black. Another finding that is consistent with this interpretation is that countries with positive ex post premiums for the 1970-2000 period tend to be countries that did not default. This is the reverse of what we would expect to find in the long run, when riskier countries should carry higher premiums. In short, the impact of the 1980s debt crisis is still noticeable in the level of long-run returns on aggregate flows and in the distribution of returns across countries.

It could also be that the true long-run risk premium on emerging-market debt is, in fact, lower than what one might expect based on the volatility of returns alone. Since the mid1980s, returns on emerging market debt have not been significantly correlated with either world or U.S. stock returns. Unfortunately, we do not have the data to compute annual returns and "betas" for the full 1970-2000 sample. From the late 1980s until 2000, the riskreturn tradeoff implied by our results seems basically consistent with the trade-offs observed for other asset classes. For the countries that did not undergo debt restructurings after the 1980s debt crisis, returns were slightly higher than those on U.S. corporate bonds in the same period. Their volatility was also higher, but, unlike U.S. corporate bonds, their returns were not significantly correlated with the U.S. stock market. For the Brady deal countries, both returns and volatility were slightly higher than those of U.S. high-yield bonds in the same period.

Some of the most interesting results of the paper refer to returns over particular subperiods. Two findings stand out, both somewhat surprising. While the 1990s were indeed a boom 
period, this was largely driven by developments during the first three or four years of the decade. Partly as a consequence of this early boom, the returns received by banks over the entire length of the debt crisis-defined as extending from the beginning of the 1970s lending cycle until the Brady deals in the early 1990s-were not as bad as one would expect based on the very low returns for the 1970-89 period. Ex post spreads were zero or even positive in several countries, and, on average, were only mildly negative, consistent with positive real interest rates.

Some common notions about the role of the official sector in emerging-debt markets can be revisited with these results in mind. This paper does not offer much support for the idea that high ex post returns during the 1990s were driven by an unexpected shift toward a much more generous official safety net. In large measure, the boom of the 1990s took place during the first half of the decade, before the Mexican bailout. It was driven by the success of the Brady deals — negotiated debt writedowns with official sponsorship — not by large-scale crisis lending. A possible conclusion is that formal debt restructuring under international rules can benefit creditors in addition to debtor countries.

This said, it is interesting that the next-best stretch for emerging-debt markets as a whole, in spite of major financial crises, was the period from 1994 to 1997. Although there may be other explanations, it is plausible that the official crisis response between 1995 and 1997 had something to do with keeping ex post returns high. It is also interesting that the best overall "performers" in our emerging-market sample include some of the Asian crisis countries and perhaps Turkey—countries that suffered major financial crises but no large-scale defaults, in part because of official sector intervention. Whether or not these relatively higher returns have been achieved at the expense of official lenders is an important question and a subject for further research. 


\section{GDF DATA ISSUES}

\section{Coverage of "Net Transfers" Reported in the GDF}

Since Lindert's (1989) initial contribution, there has been a debate about the extent to which the "net transfers" concept in the GDF needs to be adjusted for the purposes of computing internal rates of return from the creditor perspective. This appendix describes our understanding of what the "net transfers" concept exactly comprises, based both on our reading of the $G D F$ documentation (including the Debtor Reporting System questionnaires and instructions) and conversations with Bank staff who maintain this data.

In his Appendix B, Lindert (1989) argues that the reported "net transfers" concept (i.e. reported disbursements minus repayments minus interest payments) is biased down for two reasons. First, because it excludes "involuntary refinancing" during the 1980s, i.e. roll-overs in crisis situations, in which the creditor would rather get his money back but cannot. Lindert argues that by not recording "involuntary refinancing" as a disbursement, "a large share of gross new lending has been omitted from the data ... yet the data will go on reporting debt service paid on the old loans (by the unreported new ones) and may even report debt service on the new involuntary loans" (p. 268). Second, because it ignores consolidation of short term debt into long term debt. As we argued in the text, Lindert was correct on the second point. Consolidation of short term into long term debt is one of the possible cross-category stock operations which will lead to an underestimation of returns in the category which was written down (in this case, short term debt) and an overestimation in the category where stocks went up (in this case, long term debt).

Lindert's worries about "involuntary refinancing", however, reflect a misunderstanding. As explained in World Bank et al. (1988), which Lindert cites, and in more detail in World Bank (1985), Box 2, on which World Bank et al. (1988) is based, the Bank's point is merely that "involuntary refinancing", i.e. pure rollovers, are treated like a rescheduling where no flows take place and no stocks change. In other words, the distinction between "voluntary" and "involuntary" refinancing is one between an operation in which both a repayment and a new disbursement are explicitly recorded, and one where no flows are recorded as an immediate consequence of the operation. A bias cannot arise: while the Bank does not record a new disbursement in the event of an "involuntary refinancing", neither does it record a repayment. Note also that if the Bank had failed to make the distinction between "involuntary" and "voluntary" refinancing and had classified all refinancing operations as "voluntary", it would have made no difference to reported "net transfers" since the repayments and disbursements associated with involuntary rollovers would have exactly cancelled.

In addition to taking Lindert's points on board, Klingen (1994), suggests that three additional adjustments need to be made to the reported net transfers concept (1) treating debt-equity swaps as repayments, (2) treating cash buy-backs as repayments and (3) reflecting the clearance of interest arrears as repayments. As it turns out, only the first is in fact necessary 
for our purposes (again, as a special case of the broader problem of accounting for crosscategory debt stock changes). Cash payments associated with buy-backs are already captures as repayments in the $G D F$. Similarly, the Bank makes an effort to reflect clearance of interest arrears on long term debt as interest payments on long term debt, even though the accumulation of such arrears are counted as part of the short term debt stock.

\section{Stock-Flow Reconciliations}

The published GDF contain a stock-flow reconciliation for total debt (short term plus long term plus IMF debt, which is classified separately from long term debt) in Section 8 of the country tables. We now state how this relates to the stock-flow reconciliation identity presented in the text (equation 2) for the purpose of computing the residuals used in our "indirect method". We first reproduce equation (2) for easier reference:

$$
\Delta D \equiv d-r-d f r+c c v+i c+u
$$

where the residual $u^{\prime}$ is defined to include all unobservable items, i.e. $u^{\prime}=-x+u$ in the notation used earlier. As discussed, if the concept to which this identity is applied is all long term debt, then $x$ equals short term debt consolidation into long term debt.

The stock-flow identity implicit in Section 8 is as follows:

$$
\Delta D \equiv n f l+n i a-d f r+c c v+i c+u^{\prime}
$$

$n f l$ stands for "Net flows on (total) debt" and nia stands for "Net change in interest arrears"; all other terms have the same meanings, in the context of total debt, as in equation (2). The question is how the residual published in the $G D F, u$ ', relates to our residual $u$ '. Consider first the case where (2) is applied only to public and publicly guaranteed long term debt:

$$
\Delta D_{P P G} \equiv d_{P P G}-r_{P P G}-d s r_{P P G}-d f_{P P G}+c c v_{P P G}+i c_{P P G}+u_{P P G}^{\prime}
$$

Next, write (3) in long-hand after decomposing each term into the four main categories that make up total debt: short term debt, IMF debt, public and publicly guaranteed (PPG) debt and private non-guaranteed (PNG) debt. The following facts need to be reflected:

- The GDF data on cross-currency valuation ( $c c v)$ applies exclusively to PPG and IMF. There is not data on the currency composition of either short term debt or PNG long term debt, and $c c v$ for these debt categories is implicitly assumed to be zero.

- Except for ad hoc adjustments in exceptional cases, the GDF's "Net flows on debt" are defined as follows: (Disbursements on long term debt and by the IMF) - (Repayments on long term debt and to the IMF) + Change of the short term debt stock - Net change in interest arrears + Consolidation of short term debt. Thus, a consolidation of short term into long term debt leaves "net flows on debt" unaffected, because a positive entry in the last term in the definition is canceled by a reduction in the short term debt stock. 
With this in mind, identity (3) can be rewritten as follows:

$$
\begin{aligned}
& \Delta D_{T D} \equiv \Delta D_{P P G}+\Delta D_{P N G}+\Delta D_{I M F}+\Delta D_{S T D} \equiv \\
& \left(d_{P P G}-r_{P P G}\right)+\left(d_{P N G}-r_{P N G}\right)+\left(d_{I M F}-r_{I M F}\right)+\left(\Delta D_{S T D}-n i a+s t c\right) \\
& +n i a-d s r_{T D}-d f_{T D}+c c v_{P P G}+c c v_{I M F}+i c_{T D}+u_{T D}^{\prime \prime}
\end{aligned}
$$

This simplifies to:

$$
\begin{aligned}
& \Delta D_{P P G}+\Delta D_{P N G}+\Delta D_{I M F} \equiv \\
& \left(d_{P P G}-r_{P P G}\right)+\left(d_{P N G}-r_{P N G}\right)+\left(d_{I M F}-r_{I M F}\right)+s t c-d s r_{T D}-d f_{T D}+c c v_{P P G}+c c v_{I M F}+i c_{T D}+u_{T D}^{\prime \prime}
\end{aligned}
$$

Comparing (5) and (2a) it is clear that, other than referring to different debt concepts, there are only two differences between the identities:

- Short term debt consolidation leaves the published residual $u_{T D}^{\prime \prime}$ unaffected. In equation (4), short term debt consolidation implies no change on either the left hand side or right hand side of the equation, while in equation (5), a positive stc on the right hand side is offset by an equal change in the long term debt stock on the left hand side. In contrast, in (2a) short term debt consolidation is reflected in a change of the residual $u_{P P G}^{\prime}$ (short term debt consolidation leads to an increase in $\triangle D_{P P G}$ on the left hand side without an offsetting change in any of the measured items on the right hand side).

- The cross-currency valuation term included in (5) only refers to a sub item of the debt for which the stock-flow reconciliation is attempted, while it refers to the entire debt concept in (2a). Thus, we would expect the residual in (5) to contain unaccounted currency valuation effects for PNG debt, but not the residual in (2a).

To summarize: the primary economic interpretation of the residual published in the GDF is unaccounted currency valuation effects for PNG debt. The primary economic interpretation of the residual we back out of an analogous stock-flow reconciliation exercise for PPG is short term debt consolidation. In addition, as discussed in the text, both stock-flow residuals are likely to be driven by measurement error-or the discovery of measurement error, which leads to revisions in the debt stock without corresponding flows in the same period. To the extent that these occur for PPG, they would affect both the residual in equation (2a) and in equation (5). So we would expect the two residuals to be positively correlated for this reason, and indeed they are.

As discussed in the text, we also use a version of equation (2) applied to both PPG and PNG to implement our "indirect method" for a broader concept of debt that includes PNG. In that case, we attempt to estimate a $c c v$ term for PNG rather than assuming that currency valuation effects are zero for PNG, by assuming that PNG has the same currency composition as PPG for each country. Of course this assumption may be incorrect, and as a result, our residual in 
the context of this stock-flow reconciliation may also include differences between true and assume $c c v$ for PNG.

\section{Computation of Cross-Currency Valuation Adjustments}

For PPG debt owed to private creditors, the Word Bank computes cross-currency valuation adjustments according to the following definition:

$$
c c v_{t} \equiv D_{t-1} * \frac{e_{t}-e_{t-1}}{e_{t-1}}=D_{t-1}^{d} *\left(e_{t}-e_{t-1}\right)
$$

where $e_{t}$ denotes the end-period exchange rate between the U.S. dollar and the denomination currency (or currency basket) of the loan (i.e. US\$ per denomination currency unit), $D_{t}$, as before, is the debt stock outstanding at the end of year $t$ in U.S. dollars, and $D_{t}^{d}$ is the debt stock outstanding in denomination currency units.

We now show that this definition gives rise to a non-zero residual in the debt stock-flow reconciliation identity (equation (2)). First, the definition of $D_{t}$ can be rewritten as follows:

$$
\begin{aligned}
D_{t} & \equiv e_{t} D_{t}^{d} \equiv e_{t-1} D_{t-1}^{d}-e_{t-1} D_{t-1}^{d}+e_{t} D_{t}^{d} \equiv D_{t-1}-e_{t-1} D_{t-1}^{d}+e_{t}\left(D_{t-1}^{d}+D_{t}^{d}-D_{t-1}^{d}\right) \\
& \equiv D_{t-1}+c c v_{t}+e_{t}\left(D_{t}^{d}-D_{t-1}^{d}\right)
\end{aligned}
$$

Substituting into the definition of $u_{t}$ (equation (2)), and assuming that $d f r, i c$ and $x$ are zero (this is just to reduce notation; these terms would drop out in any case):

$$
\begin{aligned}
u_{t} \equiv & D_{t}-D_{t-1}-\left(d_{t}-r_{t}\right)-c c v_{t} \equiv c c v_{t}+e_{t}\left(D_{t}^{d}-D_{t-1}^{d}\right)-\left(d_{t}-r_{t}\right)-c c v_{t} \\
& \equiv e_{t}\left(d_{t}^{d}-r_{t}^{d}\right)-\left(d_{t}-r_{t}\right)
\end{aligned}
$$

Now, $d_{t} \equiv \tilde{e}_{t} d_{t}^{d}$ and $r_{t} \equiv \tilde{e}_{t} r_{t}^{d}$, where $\tilde{e}_{t}$ is the period average exchange rate in year $t$, so:

$$
u_{t} \equiv \frac{\left(e_{t}-\tilde{e}_{t}\right)}{\tilde{e}_{t}}\left(d_{t}-r_{t}\right)
$$

Thus, the $c c v$ definition (6) gives rise to non-zero residuals to the extent that average and end period exchange rates differ in any given year, which is almost always the case. As a percent of net dollar flows in a year, the residual is equal to the percentage difference between average and end-period exchange rates in the same period. This is likely to be small if the currency of denomination is a major currency, which does not fluctuate much against the dollar in most years. 


\section{SeCondary-Market Price Data, SourCes, AND Methodology ${ }^{18}$}

\section{Overview}

In the early 1980s, the suspension of principal payments by Mexico and rescheduling agreements with Brazil, Argentina, Chile, Costa Rica, Ecuador, Panama, Peru and Uruguay led to the development of a secondary market on which European and US banks began to trade defaulted loans. Prices for this market are available from the mid-1980s until the Brady agreements of the 1990s, in which debtor countries and banks negotiated the conversion of loans into "Brady bonds", whose principal was collateralized by a U.S. treasury zero-coupon bond. The initial Brady agreement_— with Mexico in January of 1990—included "par bonds" (which maintained the face value of the loan but at a reduced interest rate), "discount bonds" (which maintained market interest rates but cut the face value) and "new money bonds" (NMB), in which Bank's maintained the full claim but provided new lending. Subsequent Brady deals extended this set to a variety of other instruments including debt conversion bonds (DCB), Past Due Interest (PDI) and Capitalization bonds (C-bonds). As Brady deals were concluded, these instruments replaced loans in the secondary market. While initially dominated by the Brady bonds, a new wave of international bond issues beginning in the early 1990s gradually shifted the composition of this bond market in the direction of new issue bonds.

Aggregate secondary market debt prices for each country were compiled in two steps. First, we separately compiled debt prices for the three major categories of instruments that have been traded on secondary debt markets since the mid-1980s, namely loans, Brady bonds and other restructured instruments (for example, pre-Brady Brazilian exit and new money bonds), and new issue bonds. This three-way distinction provides one with the flexibility of either including Brady bonds with new issue bonds or treating them as successor instruments to loans for the purposes of computing rates of return in particular debt categories. We then aggregated these three categories to an overall average secondary market debt price for each country. The basic principle in both steps was to compute aggregate prices as a weighted average of the prices of the underlying instruments, weighted by the face amount outstanding. When the source used did not provide information on amounts outstanding, we used issue amounts instead (see notes on individual sources below for details). We used the following sources:

1. The LDC Debt Report (renamed to Emerging Markets Debt Report after mid 1995) a weekly newletter on developing country debt markets which was published between 1988 and 2000.

${ }^{18}$ This appendix was prepared by Priya Joshi. 
2. Financial Flows and the Developing Countries (FFDC), a quarterly publication by the World Bank published from 1988 until 1998;

3. Data obtained by Christoph Klingen in 1994 from Salomon Brothers (SB) and Latin Finance (NMB Bank, New York) through personal faxes covering end of year loan data from 1986 to 1989.

4. Instrument-level data underlying the EMBI, EMBI+ and EMBI Global Bond indices, kindly provided to us by the JP Morgan Research Department;

5. The Bloomberg financial database.

The $L D C$ debt report is the most comprehensive and easily accessible source on pre-Brady deal loan prices and was our primary source the period 1988 until the Brady deals. For the period prior to 1988, we relied primarily on Salomon Brothers data. Our main source following the Brady deal is the JP Morgan data underlying the EMBI Global index. Relative to the alternatives (primarily, the Bloomberg data base) this data has the advantage that it provides data on outstanding volumes rather than just issue volumes, and has somewhat better year-to-year continuity. However, we also used Bloomberg data to fill some holes in the other sources between 1991 and 2001 and as our primary data source for Indonesia and Malaysia (the former is not covered by the EMBI Global; for the latter, Bloomberg provides better coverage). Financial Flows and the Developing Countries was the primary data source for the Republic of Congo and the Republic of Egypt, which are not covered not in the LDC Debt Report. The Latin Finance (NMB, New York) data is used for Colombia and Panama (1986 - 1988).

In what follows, we first reproduce the results of our price compilation exercise, in summary tables containing average debt prices by country and type of instrument (loans, Bradys, bonds) and for all instruments. Next, we provide more details on compilation methodology for each source. Finally, we present some information on the representativeness of our average debt prices. 
Appendix Table 1. Aggregated Secondary-Market Prices, 1986-2001. ${ }^{1 /}$

\begin{tabular}{|c|c|c|c|c|c|c|c|c|c|c|c|c|c|c|c|c|}
\hline Country & 1986 & 1987 & 1988 & 1989 & 1990 & 1991 & 1992 & 1993 & 1994 & 1995 & 1996 & 1997 & 1998 & 1999 & 2000 & 2001 \\
\hline Algeria & n.a. & n.a. & 75.0 & 80.0 & 80.0 & 91.0 & 92.0 & 64.0 & 30.0 & n.a. & n.a. & n.a. & n.a. & 73.7 & 80.2 & 86.0 \\
\hline Argentina & 65.5 & 34.9 & 21.0 & 28.6 & 33.0 & 48.2 & 63.2 & 79.2 & 56.8 & 68.1 & 83.7 & 89.6 & 86.0 & 88.7 & 87.9 & 29.1 \\
\hline Bolivia & 7.0 & 11.0 & 10.0 & 11.0 & 9.0 & 13.9 & 16.0 & n.a. & n.a. & n.a. & n.a. & n.a. & n.a. & n.a. & n.a. & n.a. \\
\hline Brazil & 75.0 & 46.0 & 40.0 & 23.1 & 49.3 & 30.7 & 30.4 & 82.5 & 57.6 & 61.8 & 77.2 & 81.7 & 61.5 & 80.6 & 83.7 & 80.7 \\
\hline Chile & 67.0 & 61.0 & 57.0 & 59.3 & 73.3 & 89.5 & 90.0 & 90.0 & 95.0 & n.a. & n.a. & n.a. & n.a. & 93.2 & 97.1 & 101.6 \\
\hline Colombia & 84.0 & 63.0 & 57.5 & 63.5 & 64.0 & 75.0 & 75.0 & 85.0 & 89.9 & 102.3 & 100.1 & 93.3 & 83.5 & 91.8 & 83.8 & 101.3 \\
\hline Congo, Dem. Rep. of & n.a. & n.a. & 20.0 & 19.0 & 16.0 & 13.0 & 9.0 & 9.0 & 12.0 & n.a. & n.a. & n.a. & n.a. & n.a. & n.a. & n.a. \\
\hline Congo, Rep. of & n.a. & n.a. & n.a. & 15.0 & 8.0 & 4.0 & 6.0 & 9.0 & n.a. & n.a. & n.a. & n.a. & n.a. & n.a. & n.a. & n.a. \\
\hline Côte d'Ivoire & 76.0 & 40.0 & 23.0 & 7.0 & 3.0 & 7.0 & 7.0 & 15.0 & 21.0 & 16.0 & 26.0 & 35.7 & 25.3 & 16.3 & 12.0 & 14.5 \\
\hline Ecuador & 65.0 & 36.5 & 12.5 & 14.0 & 19.8 & 22.0 & 27.8 & 57.6 & n.a. & 38.2 & 58.5 & 64.6 & 43.4 & 30.0 & 46.7 & 56.1 \\
\hline Egypt & n.a. & n.a. & n.a. & 40.0 & 43.0 & 51.0 & 45.0 & 46.0 & 48.0 & 48.0 & 47.0 & 49.0 & n.a. & n.a. & n.a. & 99.5 \\
\hline Indonesia & n.a. & n.a. & 97.0 & 97.0 & 99.2 & 99.5 & 99.9 & 99.6 & 99.8 & 99.9 & 100.6 & 87.0 & 66.8 & 83.6 & 89.3 & 94.9 \\
\hline Jordan & n.a. & n.a. & n.a. & n.a. & n.a. & 30.0 & 35.0 & 52.0 & 42.0 & 47.0 & 62.9 & 71.5 & 56.6 & 66.5 & 75.4 & 84.6 \\
\hline Korea, Rep. of & n.a. & n.a. & n.a. & n.a. & n.a. & n.a. & n.a. & 100.1 & 89.7 & 103.8 & 101.2 & 79.7 & 95.1 & 99.7 & 102.0 & 108.7 \\
\hline Lebanon & n.a. & n.a. & n.a. & n.a. & n.a. & n.a. & n.a. & n.a. & 99.6 & 102.3 & 102.5 & 101.9 & 101.8 & 98.0 & 98.5 & 95.3 \\
\hline Malaysia & n.a. & n.a. & 95.4 & 96.2 & 95.4 & 96.3 & 100.6 & 102.9 & 103.8 & 99.5 & 99.8 & 97.2 & 99.3 & 104.5 & 106.4 & 107.0 \\
\hline Mexico & 56.0 & 50.0 & 42.8 & 40.6 & 53.6 & 66.1 & 71.4 & 89.8 & 64.3 & 71.5 & 86.1 & 92.0 & 85.1 & 91.5 & 101.0 & 105.3 \\
\hline Morocco & 68.0 & 52.0 & 48.0 & 38.0 & 39.3 & 46.1 & 46.8 & 79.8 & 66.0 & 64.9 & 80.4 & 85.0 & 80.5 & 87.8 & 86.5 & 88.8 \\
\hline Nigeria & 36.0 & 29.0 & 23.0 & 30.0 & 37.0 & 39.5 & 38.5 & 48.8 & 31.8 & 41.0 & 59.1 & 55.9 & 50.2 & 60.8 & 55.0 & 69.1 \\
\hline Pakistan & n.a. & n.a. & n.a. & n.a. & n.a. & n.a. & n.a. & n.a. & n.a. & n.a. & 100.8 & 94.2 & 54.7 & 71.7 & 67.5 & 90.0 \\
\hline Panama & 67.0 & 35.0 & 20.0 & 12.0 & 12.6 & 20.5 & 29.0 & 53.3 & 52.5 & n.a. & n.a. & 73.4 & 84.1 & 81.5 & 83.7 & 83.7 \\
\hline Peru & 18.0 & 7.0 & 5.0 & 5.5 & 4.0 & 11.4 & 19.3 & 68.2 & 54.7 & 72.8 & 116.0 & 62.6 & 59.9 & 65.5 & 61.7 & 73.4 \\
\hline Philippines & 72.0 & 50.0 & 33.5 & 50.0 & 36.5 & 49.6 & 57.0 & 85.2 & 74.0 & 80.4 & 96.0 & 88.2 & 89.3 & 97.3 & 86.3 & 99.5 \\
\hline Sudan & n.a. & n.a. & 2.0 & 1.0 & 2.3 & 1.0 & 1.0 & 2.0 & 3.0 & n.a. & n.a. & n.a. & n.a. & n.a. & n.a. & n.a. \\
\hline Thailand & n.a. & n.a. & n.a. & 97.5 & 94.8 & 106.8 & 109.1 & 111.4 & 102.8 & n.a. & n.a. & 82.7 & 97.3 & 98.3 & 104.3 & 108.2 \\
\hline Turkey & n.a. & n.a. & n.a. & n.a. & 86.7 & 104.9 & 102.3 & 104.9 & 85.7 & 99.4 & 100.0 & 100.5 & 88.3 & 100.4 & 91.1 & 98.7 \\
\hline Venezuela, R.B. & 74.0 & 57.0 & 40.8 & 37.7 & 56.1 & 69.0 & 58.2 & 74.1 & 46.2 & 56.2 & 83.0 & 89.2 & 63.5 & 72.8 & 74.3 & 69.8 \\
\hline
\end{tabular}

Sources: LDC Debt Report, Financial Flows and the Developing Countries, Solomon Brothers, J.P. Morgan and Bloomberg (see text).

1/ Aggregate average debt prices based on loan prices, brady prices and bond prices, calculated using the methodology described in the text. 
Appendix Table 2. Secondary-Market Loan Prices, 1986-2001. ${ }^{1 /}$

\begin{tabular}{|c|c|c|c|c|c|c|c|c|c|c|c|c|c|c|c|c|}
\hline Country & 1986 & 1987 & 1988 & 1989 & 1990 & 1991 & 1992 & 1993 & 1994 & 1995 & 1996 & 1997 & 1998 & 1999 & 2000 & 2001 \\
\hline Algeria & n.a. & n.a. & 75.0 & 80.0 & 80.0 & 91.0 & 92.0 & 64.0 & 30.0 & n.a. & n.a. & n.a. & n.a. & 73.7 & 80.2 & 86.0 \\
\hline Argentina & 65.5 & 34.9 & 21.0 & 13.0 & 20.6 & 32.3 & 43.6 & n.a. & n.a. & n.a. & n.a. & n.a. & n.a. & n.a. & n.a. & n.a. \\
\hline Bolivia & 7.0 & 11.0 & 10.0 & 11.0 & 9.0 & 13.9 & 16.0 & na & n.a. & n.a. & n.a. & n.a. & n.a. & n.a. & n.a. & n.a. \\
\hline Brazil & 75.0 & 46.0 & 40.0 & 22.3 & n.a. & n.a. & n.a. & n.a. & n.a. & n.a. & n.a. & n.a. & n.a. & n.a. & n.a. & n.a. \\
\hline Chile & 67.0 & 61.0 & 57.0 & 59.3 & 73.3 & 89.5 & 90.0 & 90.0 & 95.0 & na & n.a. & n.a. & n.a. & n.a. & n.a. & n.a. \\
\hline Colombia & 84.0 & 63.0 & 57.5 & 63.5 & 64.0 & 75.0 & 75.0 & 85.0 & 90.0 & na & n.a. & n.a. & n.a. & n.a. & n.a. & n.a. \\
\hline Congo, Dem. Rep. of & n.a. & n.a. & 20.0 & 19.0 & 16.0 & 13.0 & 9.0 & 9.0 & 12.0 & na & n.a. & n.a. & n.a. & n.a. & n.a. & n.a. \\
\hline Congo, Rep. of & n.a. & n.a. & n.a. & 15.0 & 8.0 & 4.0 & 6.0 & 9.0 & n.a. & na & n.a. & n.a. & n.a. & n.a. & n.a. & n.a. \\
\hline Côte d'Ivoire & 76.0 & 40.0 & 23.0 & 7.0 & 3.0 & 7.0 & 7.0 & 15.0 & 21.0 & 16.0 & 26.0 & 34.0 & n.a. & n.a. & n.a. & n.a. \\
\hline Ecuador & 65.0 & 36.5 & 12.5 & 14.0 & 19.8 & 22.0 & 27.8 & 52.0 & n.a. & n.a. & n.a. & n.a. & n.a. & n.a. & n.a. & n.a. \\
\hline Egypt & n.a. & n.a. & n.a. & 40.0 & 43.0 & 51.0 & 45.0 & 46.0 & 48.0 & 48.0 & 47.0 & 49.0 & na & n.a. & n.a. & n.a. \\
\hline Indonesia & n.a. & n.a. & n.a. & n.a. & n.a. & n.a. & n.a. & n.a. & n.a. & n.a. & n.a. & n.a. & n.a. & n.a. & n.a. & n.a. \\
\hline Jordan & n.a. & n.a. & n.a. & n.a. & n.a. & 30.0 & 35.0 & 52.0 & 42.0 & 47.0 & 58.0 & 67.0 & n.a. & n.a. & n.a. & n.a. \\
\hline Korea, Rep. of & n.a. & n.a. & n.a. & n.a. & n.a. & n.a. & n.a. & n.a. & n.a. & n.a. & n.a. & n.a. & n.a. & n.a. & n.a. & n.a. \\
\hline Lebanon & n.a. & n.a. & n.a. & n.a. & n.a. & n.a. & n.a. & n.a. & n.a. & n.a. & n.a. & n.a. & n.a. & n.a. & n.a. & n.a. \\
\hline Malaysia & n.a. & n.a. & n.a. & n.a. & n.a. & n.a. & n.a. & n.a. & n.a. & n.a. & n.a. & n.a. & n.a. & n.a. & n.a. & n.a. \\
\hline Mexico & 56.0 & 50.0 & 42.8 & 35.8 & n.a. & n.a. & n.a. & n.a. & n.a. & n.a. & n.a. & n.a. & n.a. & n.a. & n.a. & n.a. \\
\hline Morocco & 68.0 & 52.0 & 48.0 & 38.0 & 39.3 & 46.1 & 46.8 & 79.8 & 66.0 & 64.9 & 80.4 & 85.0 & 80.5 & 87.8 & 86.5 & 88.8 \\
\hline Nigeria & 36.0 & 29.0 & 23.0 & 30.0 & 37.0 & 39.5 & 38.5 & n.a. & n.a. & n.a. & n.a. & n.a. & n.a. & n.a. & n.a. & n.a. \\
\hline Pakistan & n.a. & n.a. & n.a. & n.a. & n.a. & n.a. & n.a. & n.a. & n.a. & n.a. & n.a. & n.a. & n.a. & n.a. & n.a. & n.a. \\
\hline Panama & 67.0 & 35.0 & 20.0 & 12.0 & 12.6 & 20.5 & 29.0 & 53.3 & 52.5 & n.a. & n.a. & n.a. & n.a. & n.a. & n.a. & n.a. \\
\hline Peru & 18.0 & 7.0 & 5.0 & 5.5 & 4.0 & 11.4 & 19.3 & 66.8 & 55.8 & 70.0 & 116.0 & n.a. & n.a. & n.a. & n.a. & n.a. \\
\hline Philippines & 72.0 & 50.0 & 33.5 & 50.0 & 36.5 & 49.6 & 57.0 & n.a. & n.a. & n.a. & n.a. & n.a. & n.a. & n.a. & n.a. & n.a. \\
\hline Sudan & n.a. & n.a. & 2.0 & 1.0 & 2.3 & 1.0 & 1.0 & 2.0 & 3.0 & na & n.a. & n.a. & n.a. & n.a. & n.a. & n.a. \\
\hline Thailand & n.a. & n.a. & n.a. & n.a. & n.a. & n.a. & n.a. & n.a. & n.a. & n.a. & n.a. & n.a. & n.a. & n.a. & n.a. & n.a. \\
\hline Turkey & n.a. & n.a. & n.a. & n.a. & n.a. & n.a. & n.a. & n.a. & n.a. & n.a. & n.a. & n.a. & n.a. & n.a. & n.a. & n.a. \\
\hline Venezuela, R.B. & 74.0 & 57.0 & 41.0 & 34.0 & n.a. & n.a. & n.a. & n.a. & n.a. & n.a. & n.a. & n.a. & n.a. & n.a. & n.a. & n.a. \\
\hline
\end{tabular}

Sources: LDC Debt Report, Financial Flows and the Developing Countries, Solomon Brothers (see text).

1/ Taken directly from datasources, without weighting. 
Appendix Table 3. Secondary-Market Brady Bond Prices, 1986-2001. ${ }^{1 /}$

\begin{tabular}{|c|c|c|c|c|c|c|c|c|c|c|c|c|c|c|c|c|}
\hline Country & 1986 & 1987 & 1988 & 1989 & 1990 & 1991 & 1992 & 1993 & 1994 & 1995 & 1996 & 1997 & 1998 & 1999 & 2000 & 2001 \\
\hline Algeria & n.a. & n.a. & n.a. & n.a. & n.a. & n.a. & n.a. & n.a. & n.a. & n.a. & n.a. & n.a. & n.a. & n.a. & n.a. & n.a. \\
\hline Argentina & n.a. & n.a. & n.a. & n.a. & n.a. & n.a. & n.a. & 77.5 & 52.1 & 63.3 & 73.5 & 80.8 & 77.4 & 77.9 & 78.8 & 39.2 \\
\hline Bolivia & n.a. & n.a. & n.a. & n.a. & n.a. & n.a. & n.a. & n.a. & n.a. & n.a. & n.a. & n.a. & n.a. & n.a. & n.a. & n.a. \\
\hline Brazil & n.a. & n.a. & n.a. & 42.4 & 49.3 & 30.7 & 29.6 & 81.8 & 57.6 & 61.6 & 76.7 & 80.5 & 60.2 & 75.7 & 77.9 & 75.1 \\
\hline Chile & n.a. & n.a. & n.a. & n.a. & n.a. & n.a. & n.a. & n.a. & n.a. & n.a. & n.a. & n.a. & n.a. & n.a. & n.a. & n.a. \\
\hline Colombia & n.a. & n.a. & n.a. & n.a. & n.a. & n.a. & n.a. & n.a. & n.a. & n.a. & n.a. & n.a. & n.a. & n.a. & n.a. & n.a. \\
\hline Congo, Dem. Rep. of & n.a. & n.a. & n.a. & n.a. & n.a. & n.a. & n.a. & n.a. & n.a. & n.a. & n.a. & n.a. & n.a. & n.a. & n.a. & n.a. \\
\hline Congo, Rep. of & n.a. & n.a. & n.a. & n.a. & n.a. & n.a. & n.a. & n.a. & n.a. & n.a. & n.a. & n.a. & n.a. & n.a. & n.a. & n.a. \\
\hline Côte d'Ivoire & n.a. & n.a. & n.a. & n.a. & n.a. & n.a. & n.a. & n.a. & n.a. & n.a. & n.a. & 35.7 & 25.3 & 16.3 & 12.0 & 14.5 \\
\hline Ecuador & n.a. & n.a. & n.a. & n.a. & n.a. & n.a. & n.a. & n.a. & n.a. & n.a. & 58.5 & 64.6 & 43.4 & 30.0 & 46.7 & 56.1 \\
\hline Egypt & n.a. & n.a. & n.a. & n.a. & n.a. & n.a. & n.a. & n.a. & n.a. & n.a. & n.a. & n.a. & n.a. & n.a. & n.a. & n.a. \\
\hline Indonesia & n.a. & n.a. & n.a. & n.a. & n.a. & n.a. & n.a. & n.a. & n.a. & n.a. & n.a. & n.a. & n.a. & n.a. & n.a. & n.a. \\
\hline Jordan & n.a. & n.a. & n.a. & n.a. & n.a. & n.a. & n.a. & n.a. & n.a. & n.a. & 62.9 & 71.5 & 56.6 & 66.5 & 75.4 & 84.6 \\
\hline Korea, Rep. of & n.a. & n.a. & n.a. & n.a. & n.a. & n.a. & n.a. & n.a. & n.a. & n.a. & n.a. & n.a. & n.a. & n.a. & n.a. & n.a. \\
\hline Lebanon & n.a. & n.a. & n.a. & n.a. & n.a. & n.a. & n.a. & n.a. & n.a. & n.a. & n.a. & n.a. & n.a. & n.a. & n.a. & n.a. \\
\hline Malaysia & n.a. & n.a. & n.a. & n.a. & n.a. & n.a. & n.a. & n.a. & n.a. & n.a. & n.a. & n.a. & n.a. & n.a. & n.a. & n.a. \\
\hline Mexico & n.a. & n.a. & n.a. & n.a. & 53.0 & 65.5 & 70.6 & 88.7 & 62.7 & 69.7 & 79.2 & 86.3 & 78.7 & 82.9 & 92.8 & 93.2 \\
\hline Morocco & n.a. & n.a. & n.a. & n.a. & n.a. & n.a. & n.a. & n.a. & n.a. & n.a. & n.a. & n.a. & n.a. & n.a. & n.a. & n.a. \\
\hline Nigeria & n.a. & n.a. & n.a. & n.a. & n.a. & n.a. & n.a. & 48.8 & 31.8 & 41.0 & 59.1 & 55.9 & 50.2 & 60.8 & 55.0 & 69.1 \\
\hline Pakistan & n.a. & n.a. & n.a. & n.a. & n.a. & n.a. & n.a. & n.a. & n.a. & n.a. & n.a. & n.a. & n.a. & n.a. & n.a. & n.a. \\
\hline Panama & n.a. & n.a. & n.a. & n.a. & n.a. & n.a. & n.a. & n.a. & n.a. & n.a. & 73.4 & 78.4 & 74.8 & 78.5 & 77.4 & 85.7 \\
\hline Peru & n.a. & n.a. & n.a. & n.a. & n.a. & n.a. & n.a. & n.a. & n.a. & n.a. & 57.5 & 62.6 & 59.9 & 65.5 & 61.7 & 73.4 \\
\hline Philippines & n.a. & n.a. & n.a. & n.a. & n.a. & n.a. & n.a. & 85.2 & 74.0 & 80.4 & 94.3 & 88.1 & 85.8 & 87.3 & 83.8 & 84.4 \\
\hline Sudan & n.a. & n.a. & n.a. & n.a. & n.a. & n.a. & n.a. & n.a. & n.a. & n.a. & n.a. & n.a. & n.a. & n.a. & n.a. & n.a. \\
\hline Thailand & n.a. & n.a. & n.a. & n.a. & n.a. & n.a. & n.a. & n.a. & n.a. & n.a. & n.a. & n.a. & n.a. & n.a. & n.a. & n.a. \\
\hline Turkey & n.a. & n.a. & n.a. & n.a. & n.a. & n.a. & n.a. & n.a. & n.a. & n.a. & n.a. & n.a. & n.a. & n.a. & n.a. & n.a. \\
\hline Venezuela, R.B. & n.a. & n.a. & n.a. & n.a. & 55.2 & 68.0 & 53.8 & 74.1 & 46.2 & 56.2 & 83.0 & 88.9 & 64.5 & 75.0 & 78.7 & 72.9 \\
\hline
\end{tabular}

Sources: LDC Debt Report, J.P. Morgan, Bloomberg (see text).

1/ Brady prices are weighted averages of all Brady issues for which prices and amount issued or amount outstanding are available. 
Appendix Table 4. Secondary-Market Non-Brady Bond Prices, 1986-2001. ${ }^{1 /}$

\begin{tabular}{|c|c|c|c|c|c|c|c|c|c|c|c|c|c|c|c|c|}
\hline Country & 1986 & 1987 & 1988 & 1989 & 1990 & 1991 & 1992 & 1993 & 1994 & 1995 & 1996 & 1997 & 1998 & 1999 & 2000 & 2001 \\
\hline Algeria & n.a. & n.a. & n.a. & n.a. & n.a. & n.a. & n.a. & n.a. & n.a. & n.a. & n.a. & n.a. & n.a. & n.a. & n.a. & n.a. \\
\hline Argentina & n.a. & n.a. & n.a. & 77.5 & 57.3 & 78.2 & 101.4 & 81.8 & 63.7 & 75.7 & 98.2 & 97.5 & 92.9 & 96.2 & 91.1 & 25.6 \\
\hline Bolivia & n.a. & n.a. & n.a. & n.a. & n.a. & n.a. & n.a. & n.a. & n.a. & n.a. & n.a. & n.a. & n.a. & n.a. & n.a. & n.a. \\
\hline Brazil & n.a. & n.a. & n.a. & n.a. & n.a. & n.a. & 96.7 & 102.4 & 97.5 & 100.6 & 99.4 & 94.6 & 71.2 & 95.9 & 91.5 & 86.1 \\
\hline Chile & n.a. & n.a. & n.a. & n.a. & n.a. & n.a. & n.a. & n.a. & n.a. & n.a. & n.a. & n.a. & n.a. & 93.2 & 97.1 & 101.6 \\
\hline Colombia & n.a. & n.a. & n.a. & n.a. & n.a. & n.a. & n.a. & n.a. & 88.2 & 102.3 & 100.1 & 93.3 & 83.5 & 91.8 & 83.8 & 101.3 \\
\hline Congo, Dem. Rep. of & n.a. & n.a. & n.a. & n.a. & n.a. & n.a. & n.a. & n.a. & n.a. & n.a. & n.a. & n.a. & n.a. & n.a. & n.a. & n.a. \\
\hline Congo, Rep. of & n.a. & n.a. & n.a. & n.a. & n.a. & n.a. & n.a. & n.a. & n.a. & n.a. & n.a. & n.a. & n.a. & n.a. & n.a. & n.a. \\
\hline Côte d'Ivoire & n.a. & n.a. & n.a. & n.a. & n.a. & n.a. & n.a. & n.a. & n.a. & n.a. & n.a. & n.a. & n.a. & n.a. & n.a. & n.a. \\
\hline Ecuador & n.a. & n.a. & n.a. & n.a. & n.a. & n.a. & n.a. & n.a. & n.a. & n.a. & n.a. & 102.8 & 90.5 & 40.3 & 47.2 & 56.4 \\
\hline Egypt & n.a. & n.a. & n.a. & n.a. & n.a. & n.a. & n.a. & n.a. & n.a. & n.a. & n.a. & n.a. & n.a. & n.a. & n.a. & 99.5 \\
\hline Indonesia & n.a. & n.a. & 97.0 & 97.0 & 99.2 & 99.5 & 99.9 & 99.6 & 99.8 & 99.9 & 100.6 & 87.0 & 66.8 & 83.6 & 89.3 & 94.9 \\
\hline Jordan & n.a. & n.a. & n.a. & n.a. & n.a. & n.a. & n.a. & n.a. & n.a. & n.a. & n.a. & n.a. & n.a. & n.a. & n.a. & n.a. \\
\hline Korea, Rep. of & n.a. & n.a. & n.a. & n.a. & n.a. & n.a. & n.a. & 100.1 & 89.7 & 103.8 & 101.2 & 79.7 & 95.1 & 99.7 & 102.0 & 108.7 \\
\hline Lebanon & n.a. & n.a. & n.a. & n.a. & n.a. & n.a. & n.a. & n.a. & 99.6 & 102.3 & 102.5 & 101.9 & 101.8 & 98.0 & 98.5 & 95.3 \\
\hline Malaysia & n.a. & n.a. & 95.4 & 96.2 & 95.4 & 96.3 & 100.6 & 102.9 & 103.8 & 99.5 & 99.8 & 97.2 & 99.3 & 104.5 & 106.4 & 107.0 \\
\hline Mexico & n.a. & n.a. & n.a. & 104.9 & 103.1 & 102.5 & 104.3 & 106.4 & 79.7 & 88.6 & 100.8 & 106.0 & 98.0 & 106.4 & 108.5 & 109.0 \\
\hline Morocco & n.a. & n.a. & n.a. & n.a. & n.a. & n.a. & n.a. & n.a. & n.a. & n.a. & 104.8 & n.a. & n.a. & n.a. & n.a. & n.a. \\
\hline Nigeria & n.a. & n.a. & n.a. & n.a. & n.a. & n.a. & n.a. & n.a. & n.a. & n.a. & n.a. & n.a. & n.a. & n.a. & n.a. & n.a. \\
\hline Pakistan & n.a. & n.a. & n.a. & n.a. & n.a. & n.a. & n.a. & n.a. & n.a. & n.a. & 100.8 & 94.2 & 54.7 & 71.7 & 67.5 & 90.0 \\
\hline Panama & n.a. & n.a. & n.a. & n.a. & n.a. & n.a. & n.a. & n.a. & n.a. & n.a. & n.a. & 95.1 & 94.4 & 90.9 & 92.6 & 99.1 \\
\hline Peru & n.a. & n.a. & n.a. & n.a. & n.a. & n.a. & n.a. & n.a. & n.a. & n.a. & n.a. & n.a. & n.a. & n.a. & n.a. & n.a. \\
\hline Philippines & n.a. & n.a. & n.a. & n.a. & n.a. & n.a. & n.a. & n.a. & n.a. & n.a. & 104.0 & 88.5 & 98.1 & 99.2 & 86.3 & 99.5 \\
\hline Sudan & n.a. & n.a. & n.a. & n.a. & n.a. & n.a. & n.a. & n.a. & n.a. & n.a. & n.a. & n.a. & n.a. & n.a. & n.a. & n.a. \\
\hline Thailand & n.a. & n.a. & n.a. & 97.5 & 94.8 & 106.8 & 109.1 & 111.4 & 102.8 & n.a. & n.a. & 82.7 & 97.3 & 98.3 & 104.3 & 108.2 \\
\hline Turkey & n.a. & n.a. & n.a. & n.a. & 86.7 & 104.9 & 102.3 & 104.9 & 85.7 & 99.4 & 100.0 & 100.5 & 88.3 & 100.4 & 91.1 & 98.7 \\
\hline Venezuela, R.B. & n.a. & n.a. & n.a. & 84.5 & 92.2 & 91.9 & 96.1 & 102.1 & 94.4 & 99.6 & 99.9 & 89.8 & 61.4 & 68.7 & 67.5 & 65.4 \\
\hline
\end{tabular}

Sources: LDC Debt Report, J.P. Morgan, Bloomberg (see text).

$1 /$ Bond prices are weighted averages of all bond issues for which prices and amount issued or amount outstanding are available. 
APPENDIX II

\section{Notes on Specific Sources}

\section{LDC Debt Report / Emerging Markets Debt Report (LDCDR)}

- Loans: The LDCDR provides one end of year loan price per country, which was used directly.

- Bradys: whenever brady or pre-brady bonds are recorded in the LDCDR, they are weighted by their issue amounts, using Bloomberg data. Brady bond prices from the LDCDR were used for the early 1990s for countries with early Brady deals.

- Bonds: The LDCDR lists a few select bonds for the early years which we used for large Latin American countries such as Argentina, Brazil, Mexico and Venezuela. We use the World Debt Tables (WDT), the Bonds, Equities and Loan (BEL) database, Bloomberg (BB) and bradynet.com to assign these bonds their respective amount issued, which are then used as weights to get the bond price by country. In case the amount issued of the bonds are unavailable from our sources we take the simple average of the bond issues. This is not a problematic assumption since the bond prices over which we are taking the average are very similar.

- "All": When only one type of issue is available, e.g. only loans or only Bradys, we replace the loan or Brady value into our "all" section. When either loan prices and Brady prices or loan and bond prices exist, we take a weighted average, using the ratio of public and publicly guaranteed debt commercial bank debt to public and publicly guaranteed bonds reported in the GDF database. When both Brady and bond prices are reported, we use issue amount information from various sources including Bloomberg, "bradynet.com", and hardcopies of the World Debt Tables as weights.

\section{J. P. Morgan data underlying the "EMBI Global" and "EMBI Plus" indices}

"EMBI Global" instruments are required to have available daily prices, a minimum of $\$ 500$ million outstanding, at least $21 / 2$ years of remaining maturity to be first included (and at least one year to remain in the index), and must be able to settle internationally. Included instruments in the index are Brady bonds, Emerging markets loans, Eurobonds and local market debt instruments issued by sovereign and quasi-sovereign entities. All of the issues are denominated in US dollars. "EMBI plus" instruments have more stringent requirements for inclusion and are typically, but not always, a subset of EMBI Global instruments. In the event that they were not already in the EMBI Global data, we added them to our instrumentlevel data to have the most complete set of instruments possible. For each instrument, we use the face amount outstanding (FACE OS) and Current Face Price Bid or Close Bid (BID). ${ }^{19}$

${ }^{19}$ We use bid prices for consistency with one of our other sources, Financial Flows and the Developing Countries, which mostly reports bid prices. 
APPENDIX II

Our first step is to classify the instruments into (non-Brady) bonds, Brady bonds and loans. One way of separating Bradys from the other bonds is to compare the data with the EMBI Index instruments, which only consist of at Brady bonds ${ }^{20}$. We then weigh each instrument within these categories using their face amounts outstanding and computed a weighted average price for that group. The same methodology is applied to get aggregate prices.

\section{Bloomberg, 1988-2001.}

We use Bloomberg data on international government bonds for our calculations of prices. (GOVT TK). All issues for which data are available are collected and sorted by Bloomberg market issue. We separate the Brady bond and non-Brady bond categories using the Bloomberg category "restructured debt" (Brady bonds and other restructured instruments). The remainder are classified as "non restructured debt", i.e. (new issue) bonds. Since Bloomberg does not keep a historical record of amount outstanding for each bond, we use information on the amount issued and issue currency in order to compute weights based on issue volume in U.S. dollars. This information is merged with Bloomberg historical data on bid prices to compute a weighted price per year, in an analogous procedure to the EMBIG weighting.

\section{Other}

As in the case of the LDC Debt report, data from Salomon Brothers (SB) and NMB Bank, New York (NMB)/Latin Finance comprises just one loan price per country, so weighting is not an issue here.

Financial Flows and the Developing Countries (FFDC) reports secondary market prices for just one instrument per country. When countries undergo Brady deals or other restructurings, a specific issue is chosen. For this reason, we use the FFDC only in rare cases.

On rare occasions, it was necessary to combine a Brady bond, non-Brady bond, or loan price from one source with a Brady bond, non-Brady bond, or loan price from another datasource to obtain an aggregated price. In the event of Brady bond and non-Brady bond price aggregation across datasources, we use amounts outstanding or amount issued as weights. In the event of a loan and bond aggregation, we use the ratio of public and publicly guaranteed bank and bonds debt stocks from the $G D F$ database.

${ }^{20}$ This is not a foolproof method since there are many countries that are not in included in the EMBI but are in the EMBIG. This comparison serves as a useful check nonetheless. 
APPENDIX II

\section{Representativeness}

Appendix Tables 5 and 6 provide information on the representativeness of our price data relative to the stock of total privately held debt (privately held public and publicly guaranteed debt plus private non-guaranteed debt) and privately held public and publicly guaranteed debt only, by dividing the total amount issued or amount outstanding used to aggregate prices with the corresponding debt stock data from the GDF. For the early years, when no issue amounts are available and country-specific representative loan prices were used to arrive at an average price (either by setting the average price is equal to the country-specific loan price, or by taking a weighted average of loan and bond prices using $G D F$ weights) the tables show the ratio of $G D F$ public and publicly guaranteed bank loans to the stock of privately held debt or PPG privately held debt, respectively. In the event that average prices are a weighted average that reflect the prices of bonds as well as loans, this would somewhat understate the true representativeness of our average prices.

The results are generally reassuring, with most representativeness rates in the 50 to 100 percent range. However, there are a few outliers in both directions. Representativeness rates above 100 percent generally have to do with using "amount issued" data rather than "amount outstanding" data in the weighting. Very low representativeness rates have to do with the use of a price sources that only provided data on one benchmark issue, in particular the $L D C$ debt report as a source for early bond issues. In addition, the JP Morgan data presently used does not include Euro denominated Eurobonds and bonds that have less than $\$ 500$ million outstanding. The first problem can be resolved by obtaining Euro-EMBIG data. A solution to the latter problem (for the Latin American countries only) is to incorporate instruments underlying JP Morgan's LEI index, which includes smaller issues. In the future, we hope to extend the data to include these instruments. 
Appendix Table 5. Representativeness of Prices in all Outstanding Privately Held Debt $\underline{1 /}$

\begin{tabular}{|c|c|c|c|c|c|c|c|c|c|c|c|c|c|c|c|c|}
\hline Country & 1986 & 1987 & 1988 & 1989 & 1990 & 1991 & 1992 & 1993 & 1994 & 1995 & 1996 & 1997 & 1998 & 1999 & 2000 & 2001 \\
\hline Algeria & & & 38.5 & 34.0 & 29.1 & 25.5 & 27.7 & 26.2 & 28.0 & & & & & 17.2 & 20.4 & 11.6 \\
\hline Argentina & 58.5 & 68.4 & 68.7 & 70.2 & 60.4 & 59.8 & 58.9 & 110.5 & 91.3 & 78.6 & 66.4 & 60.0 & 48.4 & 47.0 & 45.9 & 24.1 \\
\hline Bolivia & 47.7 & 69.8 & 2.7 & 1.0 & 0.8 & 2.2 & 2.5 & & & & & & & & & \\
\hline Brazil & 68.1 & 68.7 & 72.2 & 75.6 & 90.1 & 90.7 & 78.4 & 10.3 & 50.8 & 50.7 & 44.2 & 33.5 & 25.9 & 24.5 & 24.9 & 31.4 \\
\hline Chile & 72.4 & 76.6 & 72.6 & 61.7 & 49.9 & 44.5 & 38.0 & 32.6 & 29.1 & & & & & 1.6 & 1.5 & 4.1 \\
\hline Colombia & 61.9 & 56.3 & 58.5 & 57.3 & 58.1 & 59.3 & 55.4 & 47.6 & 45.3 & 3.4 & 2.5 & 3.7 & 5.9 & 12.0 & 11.7 & 27.8 \\
\hline Congo, Dem. Rep. of & & & 61.2 & 59.2 & 58.9 & 59.5 & 60.5 & 61.1 & 60.3 & & & & & & & \\
\hline Congo, Rep. of & & & & 53.2 & 63.3 & 59.1 & 62.1 & 74.3 & & & & & & & & \\
\hline Côte d'Ivoire & 42.8 & 46.4 & 45.9 & 45.4 & 47.7 & 48.1 & 47.8 & 46.7 & 48.3 & 49.2 & 57.0 & 27.2 & 19.2 & 20.5 & 21.4 & 22.3 \\
\hline Ecuador & 89.2 & 88.5 & 85.4 & 82.9 & 81.9 & 83.4 & 86.1 & 35.6 & & 84.4 & 81.3 & 72.6 & 76.1 & 74.8 & 65.2 & 69.7 \\
\hline Egypt & & & & 6.7 & 8.6 & 17.3 & 19.1 & 19.7 & 22.0 & 25.0 & 29.4 & 43.1 & & & & 146.0 \\
\hline Indonesia & & & 1.5 & 1.3 & 1.2 & 1.1 & 1.0 & 1.1 & & 0.6 & 1.4 & 0.7 & 0.5 & 0.6 & & 3.6 \\
\hline Jordan & & & & & & 47.6 & 51.6 & 23.5 & 20.5 & 17.6 & 36.3 & 39.8 & 44.5 & 36.5 & 56.8 & 68.2 \\
\hline Korea, Rep. of & & & & & & & & 7.2 & 6.7 & 9.9 & 12.5 & 12.9 & 15.0 & 18.1 & 15.2 & 17.2 \\
\hline Lebanon & & & & & & & & & 82.7 & 34.1 & 46.7 & 15.8 & 25.4 & 19.8 & 7.4 & 39.6 \\
\hline Malaysia & & & 19.1 & 27.0 & 34.7 & 36.8 & 22.2 & 18.0 & 2.2 & 3.0 & 2.7 & 2.3 & 0.7 & 4.8 & 6.4 & 12.0 \\
\hline Mexico & 69.9 & 72.0 & 76.5 & 77.9 & 11.2 & 45.3 & 48.6 & 43.2 & 41.1 & 38.3 & 37.5 & 30.6 & 27.7 & 24.7 & 25.0 & 34.4 \\
\hline Morocco & 45.4 & 45.5 & 52.2 & 54.1 & 53.8 & 55.6 & 57.6 & 44.8 & 42.5 & 40.8 & 43.0 & 41.9 & 37.2 & 35.9 & 32.4 & 32.7 \\
\hline Nigeria & 29.2 & 40.8 & 36.1 & 40.1 & 38.3 & 41.4 & & 73.4 & 71.7 & 74.0 & 80.2 & 92.7 & 87.0 & 84.1 & 129.8 & 129.9 \\
\hline Pakistan & & & & & & & & & & & 9.3 & 6.5 & 3.2 & 3.6 & 4.0 & 20.4 \\
\hline Panama & 83.4 & 84.7 & 84.5 & 84.2 & 83.7 & 85.9 & 86.4 & 86.7 & 97.3 & & & 68.1 & 78.7 & 71.9 & 77.7 & 75.6 \\
\hline Peru & 49.7 & 45.9 & 45.6 & 44.6 & 42.9 & 59.1 & 73.3 & 41.6 & 37.5 & 37.1 & 26.8 & 51.1 & 46.1 & 39.9 & 37.6 & 49.3 \\
\hline Philippines & 64.0 & 67.2 & 67.5 & 73.1 & 67.0 & 63.2 & 17.3 & 45.8 & 41.6 & 40.7 & 33.9 & 26.5 & 21.7 & 15.4 & 20.8 & 22.7 \\
\hline Sudan & & & 79.1 & 73.5 & 76.8 & 76.0 & 74.6 & 74.3 & 76.5 & & & & & & & \\
\hline Thailand & & & & 2.0 & 1.7 & 1.2 & & 2.4 & 0.8 & & & 1.1 & 1.1 & 1.2 & 1.5 & 1.8 \\
\hline Turkey & & & & & 3.4 & 3.3 & 5.5 & 13.9 & 0.7 & 1.9 & 1.1 & 2.1 & 1.8 & 3.2 & 8.3 & 9.4 \\
\hline Venezuela, R.B. & 68.5 & 72.4 & 72.4 & 72.1 & 51.8 & 52.6 & 53.9 & 60.0 & 60.9 & 62.1 & 62.1 & 53.6 & 46.9 & 44.2 & 38.1 & 39.5 \\
\hline
\end{tabular}

Source: Authors' calculations.

1/ Calculated as either total amount issued or amount outstanding of debt used for calculation of aggregate prices, divided by debt stock outstanding, in percent. 
Appendix Table 6. Representativeness of Prices in all Public and Publicly Guaranteed Privately Held Debt $\underline{1 /}$

\begin{tabular}{|c|c|c|c|c|c|c|c|c|c|c|c|c|c|c|c|c|}
\hline Country & 1986 & 1987 & 1988 & 1989 & 1990 & 1991 & 1992 & 1993 & 1994 & 1995 & 1996 & 1997 & 1998 & 1999 & 2000 & 2001 \\
\hline Algeria & & & 38.5 & 34.0 & 29.1 & 25.5 & 27.7 & 26.2 & 28.0 & & & & & 17.2 & 20.4 & 11.6 \\
\hline Argentina & 65.7 & 71.5 & 71.9 & 73.2 & 63.5 & 62.9 & 62.8 & 134.6 & 128.9 & 115.5 & 96.2 & 88.8 & 72.1 & 67.3 & 64.0 & 32.2 \\
\hline Bolivia & 67.8 & 82.3 & 3.7 & 1.5 & 1.2 & 3.3 & 3.7 & & & & & & & & & \\
\hline Brazil & 83.4 & 83.4 & 84.8 & 83.0 & 100.5 & 103.1 & 95.5 & 13.8 & 69.6 & 72.6 & 74.7 & 72.6 & 65.5 & 68.6 & 69.4 & 87.4 \\
\hline Chile & 93.2 & 93.1 & 91.2 & 90.5 & 90.5 & 88.3 & 86.5 & 94.4 & 97.1 & & & & & 14.0 & 15.2 & 50.5 \\
\hline Colombia & 80.2 & 72.0 & 74.4 & 69.6 & 68.6 & 69.0 & 67.6 & 64.4 & 65.3 & 6.2 & 4.8 & 7.8 & 11.4 & 21.8 & 20.8 & 50.8 \\
\hline Congo, Dem. Rep. of & & & 61.2 & 59.2 & 58.9 & 59.5 & 60.5 & 61.1 & 60.3 & & & & & & & \\
\hline Congo, Rep. of & & & & 53.2 & 63.3 & 59.1 & 62.1 & 74.3 & 86.5 & & & & & & & \\
\hline Côte d'Ivoire & 73.8 & 77.6 & 81.6 & 83.0 & 88.6 & 92.3 & 95.1 & 95.4 & 96.7 & 98.0 & 97.9 & 49.6 & 33.2 & 33.9 & 34.6 & 35.4 \\
\hline Ecuador & 90.5 & 90.0 & 87.2 & 85.2 & 84.2 & 85.5 & 87.7 & 37.2 & & 89.8 & 84.9 & 75.7 & 78.1 & 79.6 & 74.9 & 76.8 \\
\hline Egypt & & & & 8.0 & 10.0 & 21.0 & 22.8 & 23.8 & 25.8 & 29.4 & 32.2 & 48.3 & & & & 330.0 \\
\hline Indonesia & & & 2.0 & 1.9 & 2.0 & 2.1 & 2.2 & 2.3 & & 2.1 & 5.0 & 3.0 & 2.2 & 2.3 & & 13.8 \\
\hline Jordan & & & & & & 47.6 & 51.6 & 23.5 & 20.5 & 17.6 & 36.3 & 39.8 & 44.5 & 36.5 & 56.8 & 68.2 \\
\hline Korea, Rep. of & & & & & & & & 12.3 & 17.5 & 19.9 & 26.8 & 32.7 & 26.9 & 31.9 & 35.4 & 37.7 \\
\hline Lebanon & & & & & & & & & 82.7 & 35.6 & 61.4 & 24.3 & 31.7 & 22.8 & 8.4 & 42.8 \\
\hline Malaysia & & & 23.3 & 30.9 & 43.2 & 48.3 & 33.6 & 29.5 & 4.4 & 6.2 & 5.7 & 5.1 & 1.5 & 10.5 & 14.3 & 25.3 \\
\hline Mexico & 86.4 & 86.9 & 83.6 & 83.2 & 12.4 & 51.8 & 59.8 & 56.8 & 54.8 & 50.9 & 49.3 & 44.3 & 44.1 & 42.9 & 45.8 & 54.5 \\
\hline Morocco & 47.0 & 46.9 & 53.8 & 55.8 & 55.5 & 57.6 & 59.8 & 46.3 & 44.6 & 43.2 & 46.2 & 50.2 & 46.7 & 49.6 & 48.8 & 52.3 \\
\hline Nigeria & 31.1 & 42.1 & 37.1 & 41.2 & 39.4 & 42.3 & 0.0 & 76.3 & 74.4 & 76.9 & 83.8 & 97.6 & 91.2 & 87.7 & 137.8 & 137.0 \\
\hline Pakistan & & & & & & & & & & & 24.4 & 12.7 & 6.6 & 7.4 & 7.8 & 47.0 \\
\hline Panama & 83.4 & 84.7 & 84.5 & 84.2 & 83.7 & 85.9 & 86.4 & 86.7 & 97.3 & & & 74.1 & 85.4 & 81.3 & 91.4 & 87.1 \\
\hline Peru & 52.9 & 48.7 & 48.5 & 47.3 & 44.9 & 61.6 & 77.4 & 47.6 & 49.1 & 50.0 & 33.4 & 78.2 & 79.0 & 71.8 & 75.2 & 87.9 \\
\hline Philippines & 76.8 & 77.8 & 77.5 & 82.1 & 76.2 & 74.2 & 20.0 & 61.8 & 60.5 & 64.3 & 59.1 & 49.9 & 49.7 & 28.1 & 33.6 & 37.3 \\
\hline Sudan & & & 99.7 & 99.7 & 99.8 & 99.7 & 99.7 & 99.7 & & & & & & & & \\
\hline Thailand & & & & 3.9 & 4.8 & 4.5 & & 9.7 & 3.7 & & & 8.7 & 6.1 & 6.3 & 7.2 & 8.9 \\
\hline Turkey & & & & & 3.6 & 3.6 & 6.3 & 17.0 & 0.8 & 2.3 & 1.5 & 3.3 & 3.1 & 5.6 & 13.8 & 15.0 \\
\hline Venezuela, R.B. & 88.8 & 88.6 & 85.0 & 83.6 & 60.0 & 61.4 & 63.1 & 68.5 & 67.1 & 67.4 & 66.8 & 60.1 & 60.8 & 59.9 & 53.2 & 56.4 \\
\hline
\end{tabular}

Source: Authors' calculations.

1/ Calculated as either total amount issued or amount outstanding of debt used for calculation of aggregate prices, divided by debt stock

outstanding, in percent. 
APPENDIX III

\section{Computation Of Net Transfers on Alternative InVESTMent}

We want to compute IRRs on an alternative investment, assuming that the net disbursements that went into emerging debt markets had instead been used to purchase an alternative asset, indexed $A$ below.

Suppose, first, that the alternative assets is a zero coupon U.S. treasury bonds of maturity $\tau \geq 1$. Denote 0 the year in which the first bond was first purchased, and assume that purchases (disbursements) occur in the following years. The year in which the last bond is purchased is denoted $T$. Bonds are held to maturity. Then, net transfers from the creditor perspective are defined as:

$-n t_{t}^{A}=\left(1+i_{t-\tau}\right)^{\tau} d_{t-\tau}^{A}-d_{t}^{A}, T+\tau \geq t \geq 0$

where $d_{t}^{A}$ are gross disbursements at time $t$, and $i_{t}$ is the yield to maturity of the bond in period $t$. Since no bonds were purchased before date 0 , we have $d_{j}^{A}=0$ for $j<0$. Thus, $-n t_{0}^{A}=d_{0}^{A}$. Also, since no bonds are purchased after $T$, we have $d_{j}^{A}=0$ for $j>T$.

The task is to construct the flows on the right-hand side of $\left(^{*}\right)$ using our data on net debt disbursements, $n d_{t}$, and the corresponding debt stock $D_{t}$. The initial "disbursement" going to emerging markets is $p_{0} D_{0}$, so we pretend that this disbursement had gone to the alternative asset instead, i.e. $d_{0}^{A}=p_{0} D_{0}$. After that, we assume that net investments in the alternative asset (i.e. disbursements minus repayments) are the same as net disbursements to emerging markets. Using the fact that today's repayments equal disbursments $\tau \geq 1$ periods ago, we have:

$d_{t}^{A}-d_{t-\tau}^{A}=d_{t}-r_{t} \equiv n d_{t} \equiv D_{t}-D_{t-1}, T \geq t>0$

This enables us to define the required series $d_{T}^{A}, d_{T-1}^{A}, \ldots, d_{0}^{A}$ recursively, as illustrated in the following example for $\tau=3$ :

$d_{0}^{A}=p_{0} D_{0}$

$d_{1}^{A}=D_{1}-D_{0}$

$d_{2}^{A}=D_{2}-D_{1}$

$d_{3}^{A}=D_{3}-D_{2}+d_{0}^{A}$

$\cdots$

$d_{T}^{A}=D_{T}-D_{T-1}+d_{T-\tau}^{A}$ 
APPENDIX III

Now suppose that the "alternative asset" is an asset class for which a return index in available (such as the U.S. stock market). This index enables us to compute annual returns which reflect capital gains as well as any regular payments. We thus compute net transfers for this alternative index assuming it is held for one year. Let $\rho_{t}$ denote the annual return at time $t$, i.e. the percentage difference between the return index at the end of year $t$ and the end of year $t-1$. Net transfers in year $t$ are:

$-n t_{t}^{A}=-d_{t}^{A}+\left(1+\rho_{t}\right) d_{t-1}^{A}, T \geq t \geq 0$, where

$d_{0}^{A}=p_{0} D_{0}$,

$d_{t}^{A}=D_{t}-D_{t-1}+d_{t-\tau}^{A}$ for $T>t>0$, and

$d_{t}^{A}=0$ for $t \geq T$ 
APPENDIX IV

\section{COUNTRY-LEVEl RESUltS ON VOLATILITY}

Appendix Table 7. Returns, Volatility, and Betas: Results for Individual Countries

(Standard Errors in Parentheses)

\begin{tabular}{|c|c|c|c|c|c|c|c|c|c|c|c|}
\hline & \multicolumn{3}{|c|}{ Returns $\underline{1} /$} & \multirow[b]{2}{*}{$\tau_{\mathrm{p}}$} & \multicolumn{7}{|c|}{ Volatility and "Betas" 리 } \\
\hline & $1970-2000$ & $1990-2000$ & $\tau_{p}-2000$ & & St. dev. & $\beta_{\text {World }}$ & $\beta_{\mathrm{US}}$ & $\beta_{\mathrm{EM}}$ & $\beta_{\text {UScp }}$ & $\beta_{\text {UShy }}$ & $\beta_{\mathrm{eq}}$ \\
\hline Argentina & 8.8 & 16.4 & 19.8 & 1987 & 28.2 & $\begin{array}{l}-0.56 \\
(0.58)\end{array}$ & $\begin{array}{c}0.29 \\
(0.55)\end{array}$ & $\begin{array}{c}0.13 \\
(0.23)\end{array}$ & $\begin{array}{c}2.03 \\
(1.11)\end{array}$ & $\begin{array}{c}0.69 \\
(0.69)\end{array}$ & $\begin{array}{c}0.10 \\
(0.07)\end{array}$ \\
\hline $\begin{array}{l}\text { MSCI returns } \\
\text { weighted }\end{array}$ & $\begin{array}{l}\cdots \\
\ldots\end{array}$ & $\begin{array}{c}17.1 \\
314.5\end{array}$ & $\begin{array}{l}24.2 \\
83.9\end{array}$ & 1987 & 111.1 & $\begin{array}{c}3.04 \\
(2.19)\end{array}$ & $\begin{array}{c}2.71 \\
(2.04)\end{array}$ & $\begin{array}{c}1.74 \\
(0.75)\end{array}$ & $\begin{array}{c}7.40 \\
(4.46)\end{array}$ & $\begin{array}{c}6.96 \\
(1.92)\end{array}$ & $\begin{array}{l}\ldots \\
\ldots\end{array}$ \\
\hline Brazil & 8.2 & 11.1 & 14.3 & 1987 & 62.1 & $\begin{array}{l}-0.68 \\
(1.31)\end{array}$ & $\begin{array}{l}-1.49 \\
(1.15)\end{array}$ & $\begin{array}{c}0.32 \\
(0.50)\end{array}$ & $\begin{array}{l}-0.10 \\
(2.79)\end{array}$ & $\begin{array}{l}-0.75 \\
(1.57)\end{array}$ & $\begin{array}{l}-0.23 \\
(0.30)\end{array}$ \\
\hline $\begin{array}{l}\text { MSCI returns } \\
\text { weighted }\end{array}$ & $\begin{array}{l}\cdots \\
\cdots\end{array}$ & $\begin{array}{c}27.3 \\
104.7\end{array}$ & $\begin{array}{l}21.2 \\
60.8\end{array}$ & 1987 & 60.9 & $\begin{array}{c}2.32 \\
(1.10)\end{array}$ & $\begin{array}{c}0.86 \\
(1.18)\end{array}$ & $\begin{array}{c}1.18 \\
(0.35)\end{array}$ & $\begin{array}{c}0.31 \\
(2.73)\end{array}$ & $\begin{array}{c}3.17 \\
(1.23)\end{array}$ & $\begin{array}{l}\cdots \\
\ldots\end{array}$ \\
\hline Colombia & 8.1 & 9.3 & 6.3 & 1992 & 10.5 & $\begin{array}{c}0.36 \\
(0.31)\end{array}$ & $\begin{array}{c}0.03 \\
(0.26)\end{array}$ & $\begin{array}{c}0.19 \\
(0.08)\end{array}$ & $\begin{array}{c}0.14 \\
(0.56)\end{array}$ & $\begin{array}{c}0.52 \\
(0.46)\end{array}$ & $\begin{array}{c}0.06 \\
(0.14)\end{array}$ \\
\hline $\begin{array}{l}\text { MSCI returns } \\
\text { weighted }\end{array}$ & $\begin{array}{l}\cdots \\
\ldots\end{array}$ & $\begin{array}{l}\ldots \\
\ldots\end{array}$ & $\begin{array}{l}-6.8 \\
-16.1\end{array}$ & 1992 & 30.4 & $\begin{array}{c}0.50 \\
(0.98)\end{array}$ & $\begin{array}{c}0.11 \\
(0.76)\end{array}$ & $\begin{array}{c}0.30 \\
(0.31)\end{array}$ & $\begin{array}{l}-0.76 \\
(1.61)\end{array}$ & $\begin{array}{c}1.40 \\
(1.34)\end{array}$ & $\begin{array}{l}\cdots \\
\ldots\end{array}$ \\
\hline Chile & 10.2 & 14.3 & 23.4 & 1987 & 16.7 & $\ldots$ & $\cdots$ & $\cdots$ & $\ldots$ & $\cdots$ & $\ldots$ \\
\hline $\begin{array}{l}\text { MSCI returns } \\
\text { weighted }\end{array}$ & $\begin{array}{l}\cdots \\
\cdots\end{array}$ & $\begin{array}{l}14.6 \\
45.6\end{array}$ & $\begin{array}{l}20.9 \\
34.5\end{array}$ & 1987 & 37.1 & $\begin{array}{c}0.55 \\
(0.78)\end{array}$ & $\begin{array}{c}0.24 \\
(0.73)\end{array}$ & $\begin{array}{c}0.73 \\
(0.21)\end{array}$ & $\begin{array}{c}0.91 \\
(1.64)\end{array}$ & $\begin{array}{c}1.46 \\
(0.84)\end{array}$ & $\begin{array}{l}\cdots \\
\cdots \\
\cdots\end{array}$ \\
\hline Mexico & 9.7 & 14.4 & 15.0 & 1987 & 15.1 & $\begin{array}{l}-0.05 \\
(0.32)\end{array}$ & $\begin{array}{c}0.13 \\
(0.30)\end{array}$ & $\begin{array}{c}0.15 \\
(0.12)\end{array}$ & $\begin{array}{c}1.23 \\
(0.57)\end{array}$ & $\begin{array}{c}0.47 \\
(0.36)\end{array}$ & $\begin{array}{c}0.17 \\
(0.07)\end{array}$ \\
\hline $\begin{array}{l}\text { MSCI returns } \\
\text { weighted }\end{array}$ & $\begin{array}{l}\ldots \\
\ldots\end{array}$ & $\begin{array}{l}13.3 \\
53.4\end{array}$ & $\begin{array}{l}25.1 \\
73.5\end{array}$ & 1987 & 50.3 & $\begin{array}{c}1.01 \\
(1.03)\end{array}$ & $\begin{array}{c}0.87 \\
(0.96)\end{array}$ & $\begin{array}{c}1.04 \\
(0.27)\end{array}$ & $\begin{array}{l}1.75 \\
(2.19)\end{array}$ & $\begin{array}{c}1.81 \\
(1.16)\end{array}$ & $\begin{array}{l}\ldots \\
\ldots\end{array}$ \\
\hline Venezuela & 9.1 & 12.4 & 12.4 & 1992 & 37.1 & $\begin{array}{c}0.54 \\
(0.86)\end{array}$ & $\begin{array}{c}0.45 \\
(0.65)\end{array}$ & $\begin{array}{c}0.31 \\
(0.27)\end{array}$ & $\begin{array}{c}1.32 \\
(1.36)\end{array}$ & $\begin{array}{c}2.01 \\
(1.01)\end{array}$ & $\begin{array}{c}0.37 \\
(0.16)\end{array}$ \\
\hline $\begin{array}{l}\text { MSCI returns } \\
\text { weighted }\end{array}$ & $\begin{array}{l}\cdots \\
\ldots\end{array}$ & $\begin{array}{l}\cdots \\
\ldots\end{array}$ & $\begin{array}{r}4.0 \\
13.8\end{array}$ & 1992 & 37.0 & $\begin{array}{l}-0.20 \\
(1.65)\end{array}$ & $\begin{array}{c}0.03 \\
(1.26)\end{array}$ & $\begin{array}{c}0.27 \\
(0.54)\end{array}$ & $\begin{array}{l}-1.42 \\
(2.66)\end{array}$ & $\begin{array}{l}1.37 \\
(2.35)\end{array}$ & $\begin{array}{l}\ldots \\
\ldots\end{array}$ \\
\hline Indonesia & 10.4 & 7.1 & 8.3 & 1989 & 13.9 & $\begin{array}{l}-0.10 \\
(0.31)\end{array}$ & $\begin{array}{l}-0.30 \\
(0.27)\end{array}$ & $\begin{array}{c}0.20 \\
(0.11)\end{array}$ & $\begin{array}{l}-0.55 \\
(0.63)\end{array}$ & $\begin{array}{l}-0.10 \\
(0.37)\end{array}$ & $\begin{array}{c}0.13 \\
(0.07)\end{array}$ \\
\hline $\begin{array}{l}\text { MSCI returns } \\
\text { weighted }\end{array}$ & $\begin{array}{l}\cdots \\
\cdots\end{array}$ & $\begin{array}{c}-17.1 \\
1.6\end{array}$ & $\begin{array}{c}-15.2 \\
2.3\end{array}$ & 1989 & 55.4 & $\begin{array}{c}1.51 \\
(1.15)\end{array}$ & $\begin{array}{l}-0.03 \\
(1.15)\end{array}$ & $\begin{array}{c}1.07 \\
(0.37)\end{array}$ & $\begin{array}{l}-1.60 \\
(2.53)\end{array}$ & $\begin{array}{l}-0.03 \\
(1.47)\end{array}$ & $\begin{array}{l}\cdots \\
\ldots\end{array}$ \\
\hline Korea, Rep. & 9.4 & $\ldots$ & 6.0 & 1993 & 17.5 & $\cdots$ & $\cdots$ & $\cdots$ & $\ldots$ & $\cdots$ & $\ldots$ \\
\hline $\begin{array}{l}\text { MSCI returns } \\
\text { weighted }\end{array}$ & $\begin{array}{l}\cdots \\
\cdots\end{array}$ & $\begin{array}{c}-4.2 \\
\ldots\end{array}$ & $\begin{array}{l}-0.4 \\
21.8\end{array}$ & 1993 & 71.7 & $\begin{array}{l}3.24 \\
(2.10)\end{array}$ & $\begin{array}{c}0.87 \\
(1.83)\end{array}$ & $\begin{array}{c}0.73 \\
(1.02)\end{array}$ & $\begin{array}{l}-2.45 \\
(3.95)\end{array}$ & $\begin{array}{l}-2.35 \\
(3.71)\end{array}$ & $\begin{array}{l}\cdots \\
\cdots \\
\cdots\end{array}$ \\
\hline Malaysia & 9.9 & 8.8 & 8.9 & 1988 & 5.6 & $\begin{array}{l}-0.04 \\
(0.12)\end{array}$ & $\begin{array}{l}-0.12 \\
(0.10)\end{array}$ & $\begin{array}{c}0.06 \\
(0.04)\end{array}$ & $\begin{array}{l}-0.21 \\
(0.24)\end{array}$ & $\begin{array}{c}0.03 \\
(0.14)\end{array}$ & $\begin{array}{c}0.04 \\
(0.03)\end{array}$ \\
\hline $\begin{array}{l}\text { MSCI returns } \\
\text { weighted }\end{array}$ & $\begin{array}{l}\cdots \\
\cdots\end{array}$ & $\begin{array}{c}1.0 \\
13.4\end{array}$ & $\begin{array}{l}-4.7 \\
21.2\end{array}$ & 1988 & 52.1 & $\begin{array}{c}1.53 \\
(1.05)\end{array}$ & $\begin{array}{l}-0.01 \\
(1.04)\end{array}$ & $\begin{array}{c}1.15 \\
(0.25)\end{array}$ & $\begin{array}{l}-0.78 \\
(2.34)\end{array}$ & $\begin{array}{c}0.26 \\
(1.34)\end{array}$ & $\begin{array}{l}\cdots \\
\ldots\end{array}$ \\
\hline Philippines & 6.6 & 24.3 & 18.5 & 1987 & 29.8 & $\begin{array}{c}0.90 \\
(0.58)\end{array}$ & $\begin{array}{c}0.76 \\
(0.55)\end{array}$ & $\begin{array}{c}0.61 \\
(0.17)\end{array}$ & $\begin{array}{c}1.92 \\
(1.21)\end{array}$ & $\begin{array}{c}1.17 \\
(0.68)\end{array}$ & $\begin{array}{c}0.47 \\
(0.10)\end{array}$ \\
\hline $\begin{array}{l}\text { MSCI stock rt } \\
\text { weighted }\end{array}$ & $\begin{array}{l}\cdots \\
\cdots\end{array}$ & $\begin{array}{c}2.9 \\
62.3\end{array}$ & $\begin{array}{c}4.2 \\
37.0\end{array}$ & 1987 & 51.9 & $\begin{array}{c}1.94 \\
(0.94)\end{array}$ & $\begin{array}{c}0.67 \\
(1.01)\end{array}$ & $\begin{array}{c}1.12 \\
(0.26)\end{array}$ & $\begin{array}{c}2.28 \\
(2.22)\end{array}$ & $\begin{array}{c}2.36 \\
(1.12)\end{array}$ & $\begin{array}{l}\cdots \\
\cdots\end{array}$ \\
\hline Thailand & 10.8 & 7.5 & 8.1 & 1989 & 10.7 & $\begin{array}{c}0.07 \\
(0.24)\end{array}$ & $\begin{array}{l}-0.03 \\
(0.22)\end{array}$ & $\begin{array}{c}0.06 \\
(0.10)\end{array}$ & $\begin{array}{c}0.27 \\
(0.49)\end{array}$ & $\begin{array}{c}0.08 \\
(0.28)\end{array}$ & $\begin{array}{c}0.11 \\
(0.06)\end{array}$ \\
\hline $\begin{array}{l}\text { MSCI returns } \\
\text { weighted }\end{array}$ & $\begin{array}{l}\cdots \\
\cdots\end{array}$ & $\begin{array}{l}-9.8 \\
1.3\end{array}$ & $\begin{array}{l}-11.5 \\
-2.6\end{array}$ & 1989 & 48.2 & $\begin{array}{c}1.60 \\
(0.96)\end{array}$ & $\begin{array}{c}0.14 \\
(1.00)\end{array}$ & $\begin{array}{c}1.05 \\
(0.28)\end{array}$ & $\begin{array}{c}0.46 \\
(2.25)\end{array}$ & $\begin{array}{c}1.27 \\
(1.21)\end{array}$ & $\begin{array}{l}\cdots \\
\cdots\end{array}$ \\
\hline Turkey & 9.3 & 7.8 & 7.8 & 1990 & 12.5 & $\begin{array}{c}0.59 \\
(0.28)\end{array}$ & $\begin{array}{c}0.48 \\
(0.23)\end{array}$ & $\begin{array}{c}0.21 \\
(0.09)\end{array}$ & $\begin{array}{c}1.02 \\
(0.47)\end{array}$ & $\begin{array}{c}0.81 \\
(0.22)\end{array}$ & $\begin{array}{c}0.03 \\
(0.04)\end{array}$ \\
\hline $\begin{array}{l}\text { MSCI returns } \\
\text { weighted }\end{array}$ & $\begin{array}{l}\cdots \\
\ldots\end{array}$ & $\begin{array}{c}6.6 \\
30.0\end{array}$ & $\begin{array}{c}6.6 \\
30.0\end{array}$ & 1990 & 109.7 & $\begin{array}{c}5.16 \\
(2.47)\end{array}$ & $\begin{array}{c}1.19 \\
(2.46)\end{array}$ & $\begin{array}{c}2.04 \\
(0.76)\end{array}$ & $\begin{array}{l}-2.72 \\
(5.10)\end{array}$ & $\begin{array}{c}0.00 \\
(3.17)\end{array}$ & $\begin{array}{l}\ldots \\
\ldots\end{array}$ \\
\hline
\end{tabular}

Sources: Morgan Stanley, and authors' calculations.

1/ Gross US dollar returns. Debt returns refer to public and publicly guaranteed debt, private creditors, and average of "direct" and "indirect" approaches.

2/ Based on annual returns. 
Appendix Table 8. Returns over One-Year Holding Periods $\underline{1}$

\begin{tabular}{|c|c|c|c|c|c|c|c|c|c|c|c|c|c|c|}
\hline & $1986-87$ & $1987-88$ & 1988-89 & $1989-90$ & $1990-91$ & $1991-92$ & $1992-93$ & $1993-94$ & $1994-95$ & $1995-96$ & $1996-97$ & $1997-98$ & $1998-991$ & $\overline{99-2000}$ \\
\hline All countries 2/ & $\ldots$ & $\ldots$ & $\ldots$ & $\ldots$ & 20.1 & 14.9 & 45.9 & -16.4 & 19.7 & 21.8 & 5.8 & -4.3 & 18.6 & 7.2 \\
\hline All Brady countries 2/ & -20.5 & -5.0 & 15.2 & 67.4 & 19.2 & 17.8 & 62.8 & -23.8 & 21.5 & 30.7 & 9.1 & -5.8 & 18.7 & 9.9 \\
\hline All non-Brady countries $\underline{2} /$ & $\ldots$ & $\ldots$ & $\ldots$ & $\ldots$ & 22.1 & 9.6 & 15.4 & 1.8 & 16.6 & 5.0 & -2.2 & -0.6 & 18.2 & 1.0 \\
\hline Latin America countries 2/ & -18.0 & -2.8 & 10.2 & 70.9 & 17.2 & 16.9 & 61.3 & -23.9 & 21.0 & 28.5 & 9.1 & -6.4 & 18.5 & 10.4 \\
\hline Argentina & -43.2 & -17.9 & 50.4 & 72.5 & 64.1 & 38.4 & 10.9 & -25.9 & 27.7 & 23.7 & 11.5 & 4.3 & 7.1 & 4.8 \\
\hline MSCI stock returns: & $\ldots$ & 102.6 & 81.2 & -6.1 & 405.0 & -38.5 & 58.4 & -23.6 & 12.9 & 20.3 & 24.6 & -24.3 & 34.3 & -25.1 \\
\hline Brazil & -22.8 & 8.2 & -19.2 & 146.1 & -34.0 & 12.3 & 181.3 & -28.0 & 17.3 & 30.9 & 9.1 & -17.6 & 36.8 & 11.4 \\
\hline MSCI stock returns: & $\ldots$ & 103.4 & 38.7 & -61.6 & 172.2 & 6.7 & 77.7 & 65.7 & -19.2 & 42.5 & 27.3 & -39.6 & 67.2 & -11.4 \\
\hline Colom & -9.1 & 0.9 & 23.6 & 18.8 & 31.4 & 10.5 & 19.9 & 13.6 & 21.2 & 2.0 & -3.8 & -5.1 & 16.0 & -2.9 \\
\hline$M S C I s$ & $\ldots$ & $\ldots$ & $\ldots$ & $\ldots$ & $\ldots$ & $\ldots$ & 31.3 & 21.3 & -25.5 & 11.1 & 41.8 & -42.2 & -13.7 & -38.9 \\
\hline Mexico & 3.4 & 1.8 & 23.5 & 33.2 & 34.8 & 14.2 & 32.6 & -22.2 & 19.9 & 23.6 & 13.7 & 1.0 & 15.1 & 17.2 \\
\hline MSCI stock returns: & $\ldots$ & 72.0 & 89.2 & 62.7 & 126.0 & 25.0 & 49.4 & -40.6 & -20.4 & 18.7 & 53.9 & -33.5 & 80.1 & -20.5 \\
\hline Venezuela & -11.1 & -16.3 & 13.9 & 73.7 & 35.0 & -8.8 & 34.3 & -29.2 & 39.4 & 56.4 & 11.2 & -18.8 & 24.5 & 11.0 \\
\hline MSCI stock returns: & $\ldots$ & $\ldots$ & $\ldots$ & $\ldots$ & $\ldots$ & $\ldots$ & 20.9 & -14.5 & -22.7 & 131.2 & 28.3 & -49.2 & 8.7 & 4.5 \\
\hline Memorandum: Chile & 10.8 & 13.3 & 37.5 & 55.4 & 38.4 & 8.6 & 8.7 & 13.9 & $\ldots$ & $\ldots$ & $\ldots$ & $\ldots$ & $\ldots$ & 11.2 \\
\hline MSCI stock returns: & $\ldots$ & 40.2 & 64.0 & 31.1 & 116.1 & 21.9 & 36.6 & 44.8 & -2.7 & -13.5 & 5.5 & -28.5 & 39.0 & -15.1 \\
\hline Asian countries $2 /$ & $\ldots$ & $\ldots$ & $\ldots$ & 11.3 & 19.2 & 10.7 & 17.3 & 6.6 & 7.1 & 7.2 & -6.9 & 2.9 & 20.0 & 5.3 \\
\hline Indonesia & $\ldots$ & & 10.4 & 15.4 & 10.5 & 5.5 & 9.7 & 11.6 & 9.6 & 6.0 & -9.4 & -23.2 & 35.4 & 12.9 \\
\hline MSCI stock returns: & $\ldots$ & 258.1 & 81.9 & 6.4 & -44.5 & -0.2 & 105.7 & -25.9 & 9.2 & 27.5 & -74.1 & -31.5 & 93.5 & -61.9 \\
\hline Malaysia & $\ldots$ & & 6.0 & 13.8 & 15.2 & 15.8 & 11.7 & 9.1 & -0.6 & 4.0 & 0.0 & 11.7 & 14.6 & 5.6 \\
\hline$M S$ & $\ldots$ & 27.3 & 57.0 & -7.0 & 5.8 & 8.6 & 109.5 & -20.1 & 4.7 & 25.5 & -68.0 & -30.8 & 114.3 & -16.0 \\
\hline Philip & -19.6 & -7.7 & 82.2 & -7.4 & 65.2 & 24.1 & 65.7 & -5.1 & 16.3 & 25.2 & -4.8 & 11.1 & 18.2 & -6.4 \\
\hline MSCI stock returns: & $\ldots$ & 43.1 & 65.0 & -45.6 & 85.5 & 39.0 & 122.3 & -7.9 & -11.5 & 17.7 & -62.6 & 13.5 & 3.3 & -45.0 \\
\hline Thailand & $\ldots$ & & & 12.4 & 21.6 & 7.3 & 10.9 & 2.9 & 6.0 & 0.7 & -16.4 & 27.1 & 9.4 & 8.8 \\
\hline MSCI stock returns: & $\ldots$ & 47.3 & 114.4 & -27.3 & 22.7 & 35.4 & 103.6 & -9.0 & -3.8 & -36.6 & -73.4 & 11.6 & 47.2 & -56.3 \\
\hline Memorandum: Korea, Rep. & $\ldots$ & & & & & 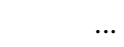 & $\ldots$ & -10.0 & 26.0 & -0.2 & -27.2 & 18.0 & 20.4 & 7.1 \\
\hline MSCI stock returns: & $\cdots$ & 96.6 & 1.7 & -27.3 & -15.5 & 1.6 & 31.4 & 23.7 & -3.3 & -38.1 & -66.7 & 141.1 & 92.4 & -49.6 \\
\hline Turkey & $\ldots$ & & & $\ldots$ & 30.3 & 4.5 & 13.0 & -5.9 & 28.0 & 3.0 & 2.0 & -1.0 & 16.8 & -6.6 \\
\hline MSCI stock returns: & & -59.3 & 547.2 & -5.3 & -18.5 & -44.6 & 220.5 & -50.5 & -2.8 & 36.9 & 118.1 & -52.5 & 252.4 & -45.6 \\
\hline MSCI U.S. I & 3.9 & 15.9 & 31.4 & -2.1 & 31.3 & 7.4 & 10.1 & 2.0 & 38.2 & 24.1 & 34.1 & 30.7 & 22.4 & -12.5 \\
\hline MSCI AC World Stock Return & $\ldots$ & 24.0 & 17.6 & -16.5 & 19.9 & -4.2 & 24.9 & 5.0 & 19.5 & 13.2 & 15.0 & 22.0 & 26.8 & -13.9 \\
\hline MSCI Emerging Markets Stock & $\cdots$ & 40.4 & 65.0 & -10.6 & 59.9 & 11.4 & 74.8 & -7.3 & -5.2 & 6.0 & -11.6 & -25.3 & 66.4 & -30.6 \\
\hline 10-Year $\mathrm{Tr}$ & -3.22 & 6.46 & 6.39 & 6.72 & 17.25 & 6.44 & 1.97 & -7.90 & 23.72 & 0.08 & 11.20 & 13.05 & -8.35 & 14.46 \\
\hline ML US Treasury Master & 1.98 & 7.06 & 14.30 & 8.65 & 15.20 & 7.21 & 10.63 & -3.35 & 18.45 & 2.61 & 9.62 & 10.03 & -2.38 & 13.37 \\
\hline ML US Corporate Master & 1.84 & 9.74 & 14.07 & 7.43 & 18.24 & 9.12 & 12.43 & -3.36 & 21.53 & 3.43 & 10.39 & 8.72 & -1.89 & 9.13 \\
\hline ML US High Yield Master & 4.47 & 13.36 & 2.31 & -4.36 & 39.17 & 17.44 & 16.69 & -1.03 & 20.46 & 11.27 & 13.27 & 2.95 & 2.51 & -5.12 \\
\hline
\end{tabular}

Sources: Morgan Stanley, Merrill Lynch, and Authors' calculations.

1/ Gross returns. Except where otherwise noted, returns refer to public and publicly guaranteed debt, private creditors, average of "direct" and "indirect" approaches.A14 2/ Refers only to countries shown in Tables 9 and 10, excluding memorandum countries. 


\section{REFERENCES}

Bekaert, Geert and Campbell R. Harvey, 1997, “Emerging Equity Market Volatility,” Journal of Financial Economics Vol. 43 (January), pp. 29-77

— 2000, "Capital Flows and the Behavior of Emerging Market Equity Returns," in Capital flows and the emerging economies: Theory, evidence, and controversies (NBER Conference Report series, Chicago and London: University of Chicago Press), pp.159-94.

Bulow, Jeremy, and Kenneth Rogoff, 1990, "Cleaning Up Third World Debt without Getting Taken to the Cleaners,” Journal of Economic Perspectives, Vol. 4 (Winter), pp. 31-42.

Cohen, Daniel, 1992, “The Debt Crisis: A Post Mortem,” in NBER Macroeconomics Annual 1992, edited by Olivier Blanchard and Stanley Fischer (Cambridge, Mass. and London: The MIT Press), pp. 65-105 (also issued, with an appendix on data issues, as CEPR Discussion Paper No. 692, August 1992).

Dell’Ariccia, Giovanni, Isabel Schnabel, and Jeromin Zettelmeyer, 2002, "Moral Hazard and International Crisis Lending: A Test,” IMF Working Paper No. 02/181 (Washington: International Monetary Fund).

Dooley, Michael, Richard D. Haas, and Steven Symansky, 1993, “A Note on Burden Sharing Among Creditors,” IMF Staff Papers, Vol. 40, No. 1, pp. 226-32.

Eichengreen, Barry, and Richard Portes, 1986, "Debt and Default in the 1930s: Causes and Consequences,” European Economic Review, Vol. 30 (June), pp. 599-640.

Elton, Edwin J., Martin J. Gruber, Deepak Agrawal, and Christopher Mann, 2001, "Explaining the Rate Spread on Corporate Bonds,” Journal of Finance, Vol. 56 (February), pp. 247-275.

Erb, Claude B., Campbell R. Harvey, and Tadas E. Viskanta, 1999, "New Perspectives on Emerging Market Bonds,” Journal of Portfolio Management, Vol. 25 (Winter), pp. 83-92

Goetzmann, William N., and Philippe Jorion, 1999, “Re-Emerging Markets,” Journal of Financial and Quantitative Analysis, Vol. 34 (March), pp. 1-32.

Harvey, Campbell R., 1995a, The Risk Exposure of Emerging Equity Markets, World Bank Economic Review, Vol. 9 (January), pp. 19-50.

— Studies, Vol. 8 (Fall), pp. 773-816. 
Karolyi, G. Andrew, and Rene M. Stulz, 2002, "Are Financial Assets Priced Locally or Globally?”, NBER Working Paper No. 8994 (Cambridge, MA: National Bureau of Economic Research).

Kelly, Jonathan M., Luis F. Martins, and John H. Carlson, 1998, "The Relationship between Bonds and Stocks in Emerging Countries," Journal of Portfolio Management, Vol. 24 (Spring), pp. 110-22.

Klingen, Christoph, 1994, "How Private Creditors Fared with Sovereign Lending: Evidence from the 1970-1992 Period," WWZ Discussion Paper No. 9424, University of Basel.

Lane, Philip R., and Gian Maria Milesi-Ferretti, 2002, "External Wealth, the Trade Balance, and the Real Exchange Rate," European Economic Review, Vol. 46 (June), pp.1049-71.

— 2003, “International Financial Integration,” IMF Working Paper No. 03/86 (Washington: International Monetary Fund).

Lindert, Peter H., 1989, "Response to Debt Crisis: What Is Different about the 1980s?", in The International Debt Crisis in Historical Perspective, edited by Barry Eichengreen and Peter H. Lindert (Cambridge, Mass. and London: The MIT Press), pp. 227-75.

— Country Debt and Economic Performance, Vol. 1, edited by Jeffrey D. Sachs (Chicago and London: The University of Chicago Press), pp. 39-105.

Rogoff, Kenneth, 1990, "Symposium on New Institutions for Developing Country Debt," Journal of Economic Perspectives, Vol. 4 (Winter), pp. 3-6.

Rouwenhorst, K. Geert, 1999, "Local Return Factors and Turnover in Emerging Stock Markets," Journal of Finance, Vol. 54 (August), pp. 1439-64.

World Bank, 1995, World Debt Tables 1984/85 (Washington: World Bank).

_- International Monetary Fund, Bank for International Settlements, Organisation for Economic Cooperation and Development, 1988, External Debt. Definition, Statistical Coverage and Methodology (Paris: Organization for Economic Cooperation and Development).

Zhang, Xiaoming Alan, 1999, "Testing for 'Moral Hazard' in Emerging Markets Lending," Institute of International Finance Research Paper No. 99-1. 